University of Michigan Law School University of Michigan Law School Scholarship Repository

Articles

Faculty Scholarship

2003

\title{
Redistributing Optimally: Of Tax Rules, Legal Rules, and Insurance
}

Kyle D. Logue

University of Michigan Law School, klogue@umich.edu

Ronen Avraham

University of Texas Law School, ravraham@law.utexas.edu

Available at: https://repository.law.umich.edu/articles/1737

Follow this and additional works at: https://repository.law.umich.edu/articles

Part of the Insurance Law Commons, Law and Economics Commons, Social Welfare Law Commons, and the Tax Law Commons

\section{Recommended Citation}

Logue, Kyle D. "Redistributing Optimally: Of Tax Rules, Legal Rules, and Insurance." R. Avraham, co-author. Tax L. Rev. 56, no. 2 (2003): 157-257.

This Article is brought to you for free and open access by the Faculty Scholarship at University of Michigan Law School Scholarship Repository. It has been accepted for inclusion in Articles by an authorized administrator of University of Michigan Law School Scholarship Repository. For more information, please contact mlaw.repository@umich.edu. 


\title{
Redistributing Optimally: Of Tax Rules, Legal Rules, and Insurance
}

\author{
KYLE LOGUE* AND RONEN AVRAHAM**
}

\section{INTRODUCTION}

From the beginning of the law and economics movement, normative legal economists have focused almost exclusively on evaluating the efficiency of alternative legal rules. The distributional consequences of legal rules, therefore, have largely been ignored. It is tempting to conclude that legal economists are hostile or indifferent to concerns of distributional fairness. In fact, however, the discipline of economics has a great deal to say about distributional policy.

The normative branch of economics, known as welfare economics, has always been deeply concerned with distributional issues. ${ }^{1}$ It is not that welfare economists purport to know a priori the "right" or "optimal" distribution of resources. To the contrary, the standard approach among public finance economists has been to remain neutral on the types of inequality in society that ought to be the target of redistributive policy and how much, if any, redistribution is appropriate. ${ }^{2}$ If those same economists, however, were provided with a theory of distributive justice, they then could build that theory into their

* Professor of Law, University of Michigan.

** Assistant Professor of Law, Northwestern University. We would like to thank Adi Ayal, David Bradford, Richard Craswell, Steve Croley, Hanoch Dagan, Tsilly Dagan, Jim Hines, Louis Kaplow, Deborah Schenk, Steven Shavell, Daniel Shaviro, David Weisbach, and participants at the Bar-Ilan University Faculty Seminar (Israel), the University of Chicago Law \& Economics Workshop, the NYU Tax Policy Colloquium, the Stanford Law School Distributive Justice Colloquium, the Stanford Law \& Economics Workshop, and the 2002 ALEA Conference at Harvard Law School for helpful comments. We also thank the Cook Fund and the John M. Olin Foundation at the University of Michigan Law School for generous research support. All errors in this Article are, of course, our responsibility.

1 The most comprehensive exposition of the welfarist approach to evaluating public policy is found in Louis Kaplow \& Steven Shavell, Fairness Versus Welfare, 114 Harv. L. Rev. 961 (2001) [hereinafter Fairness I]. They subsequently turned their article into a book. Louis Kaplow \& Steven Shavell, Fairness Versus Welfare (2002) [hereinafter Fairness II].

2 See Kaplow \& Shavell, Fairness II, note 1, at 27 ("[W]e do not endorse any particular view about the proper distribution of well-being or income."); Kaplow \& Shavell, Fairness I, note 1, at 988 (same); see also Harvey S. Rosen, Public Finance 142-60 (5th ed. 1999); Joseph E. Stiglitz, Economics of the Public Sector 94-103, 476-79 (3d ed. 2000). 
framework for evaluating public policy. ${ }^{3}$ Indeed, economists have created mathematical models of tax regimes to accommodate any number of theories of distributive justice: from the Rawlsian maximin criterion, which manifests a special concern for the well-being of the least advantaged members in society, to the various versions of utilitarianism, which, depending on the assumptions, can justify complete equalization of income or redistribution from the worse off to the better off. ${ }^{4}$ Again, while economists are able to build these theories into their models, they typically do not endorse any particular theory of distributive justice.

Many economists and most law and economics scholars, however, are far from neutral with regard to how to accomplish redistribution. To the contrary, although (as far as we know) no polls have been conducted on this question, we believe it is a safe bet that a majority of legal economists hold the following view: Whatever amount of redistribution is deemed appropriate or desirable, the exclusive policy tool for redistributing to reduce income or wealth inequality should always be the tax-and-transfer system. ${ }^{5}$ Under this view, the legal system, by contrast, should never be used to reduce income inequality, but instead should be used only to achieve efficiency. To put this view in more colloquial terms, the legal system should be used only to maximize the size of the pie; the tax-and-transfer system should be the exclusive means of slicing it.

This conventional economic view of the appropriate division of functions between the legal system and the tax-and-transfer system

3 Indeed, determining how best to achieve society's preferences regarding distributional fairness is one of the primary objectives of the economic subliterature on optimal taxation. See, e.g., William Vickrey, Agenda for Progressive Taxation (1947); J.A. Mirrlees, An Exploration in the Theory of Optimum Income Taxation, 38 Rev. Econ. Stud. 175 (1971). Both Vickrey and Mirrlees were the 1996 recipients of the Nobel Prize in Economic Sciences. See Press Release, The Royal Swedish Academy of Sciences, The Sveriges Riksbank (Bank of Sweden) Prize in Economic Sciences in Memory of Alfred Nobel for 1996 (Oct. 8, 1996) (last modified Aug. 27, 2002) http://www.nobel.se/economics/laureates/1996/ press.html (mentioning their contributions regarding redistributive taxation).

${ }^{4}$ See generally Rosen, note 2, at 147-54 (discussing different views as to whether government should undertake redistributional policies and summarizing the implications for redistributive policy of Rawlsian and utilitarian social welfare functions). For a comprehensive formal treatment of different theories of distributive justice, see John E. Roemer, Theories of Distributive Justice (1996).

5 See, e.g., A. Mitchell Polinsky, An Introduction to Law and Economics 124-27 (2d ed. 1989); Louis Kaplow \& Steven Shavell, Why the Legal System Is Less Efficient Than the Income Tax in Redistributing Income, 23 J. Legal Stud. 667 (1994) [hereinafter Legal System]. As tax scholars know, the term "income" is far from self-defining. The same is true of the terms "consumption" and "wealth," which commonly are suggested as alternative tax bases. In Section II we say a few words about what we mean by the term income for purposes of this Article. As have the other participants in the redistributive rules debate, we take no position on whether income or consumption or wealth is the best measure of ability to pay but generally regard them as interchangeable for this analysis. 
also seems to have produced a clear division of labor among welfarist policy analysts. ${ }^{6}$ On the one hand, tax scholars who apply the welfarist framework evaluate alternative tax regimes according to their ability to produce the desired level of revenue for the government to spend on public goods while at the same time producing the smallest amount of distortion and satisfying society's distributional preferences. On the other hand, legal economists in nontax fields spend their time evaluating legal rules-such as the private law doctrines of contract, property, and tort-solely on the basis of those rules' ability or inability to correct market failures: to internalize externalities, minimize transaction costs, provide efficient investment incentives, and generally help achieve allocational efficiency in the economy. ${ }^{7}$ It is this division of labor that justifies the legal economists' tendency to ignore distributional concerns. ${ }^{8}$

6 "Welfarism" refers to a normative political theory that calls for government policy decisions to be made solely on the basis of their effects on the welfare of individuals in society. Kaplow \& Shavell, Fairness II, note 1, at 3-4. Sometimes welfarism is equated with welfare economics. See generally id.

7 For a list of justifications for this division of labor among welfarist policy analysts, see Kaplow \& Shavell, Fairness II, note 1, at 31-35; Kaplow \& Shavell, Fairness I, note 1, at 992-95.

8 Chris Sanchirico calls this justification for legal economists' exclusive focus on the efficiency of legal rules the "new efficiency rationale." Chris William Sanchirico, Deconstructing the New Efficiency Rationale, 86 Cornell L. Rev. 1003, 1007 (2001) [hereinafter Efficiency Rationale]. The new efficiency rationale, as Sanchirico notes, has roots in the basic theories of welfare economics. In fact, this conventional view among legal economists can be understood as deriving from the Second Fundamental Theorem of Welfare Economics, which is centrally important to the law and economics movement and to normative economics generally. The Second Theorem states, in effect, that under the conditions of perfect competition a market economy can lead to any Pareto optimal point, that is, any efficient point, provided the government has the ability to make a lump sum redistributive transfer of wealth. Recall that a "Pareto optimal" point is a distribution of resources in society that is efficient, that is, a point from which no one can be made better off without making someone else worse off. Such points are normatively significant, according to the welfare economist, because reaching a Pareto optimal point means that, from a particular starting point in terms of resource entitlements, all available gains from voluntary trade have been made. Thus, achieving Pareto optimality maximizes social welfare if one assumes that the initial allocation of wealth was consistent with society's overall distributional preferences as embedded in its social welfare function and that all trade is fully informed and voluntary. The innovation of the Second Theorem is to show that, even if the initial allocation of resources is inconsistent with the social welfare function, the fully competitive market nevertheless can maximize social welfare (including society's distributional concerns) if there is a perfectly nondistortive (or lump sum) system for making redistributive transfers. Thus, the Second Theorem contains in it the division of functions between legal rules (correcting market failures and promoting competitive markets) and tax rules (correcting distributional inequities). This division of labor remained even when it became clear to scholars that no practical means of making nondistortive lump sum transfers exists. A major theme in this Article is that this division of labor has been drawn too starkly, and that the choice of the optimal policy instrument depends on comparative institutional advantage. 
The economists' emphasis on the tax-and-transfer system as the primary means of redistribution is unremarkable. As we argue in Section III, a good case can be made that the tax-and-transfer system should be the primary instrument for achieving society's income- or wealth-redistributive goals. What is somewhat remarkable, however, is the claim that the tax-and-transfer system should be the exclusive tool for income redistribution. ${ }^{9}$ What is more puzzling is the almost exclusive focus on money income or wealth as the target of redistributive policy. Of course, for economists and welfarist policy scholars generally, well-being rather than income or wealth is the ultimate target. Income or wealth is merely a proxy for the underlying characteristic of subjective well-being. ${ }^{10}$ Therefore, those scholars would likely

9 We recognize that, within the discipline of economics, there continue to be vigorous
debates over the extent to which various policy instruments should be designed to further
redistributive goals. To take just two examples, economists continue to debate whether it
would be desirable to use distributional weights in regulatory cost-benefit analysis, e.g.,
Arnold C. Harberger, On the Use of Distributional Weights in Social Cost-Benefit Analy-
sis, $86 \mathrm{~J}$. Pol. Econ. S87 (1978), as well as the use of educational subsidies rather than wage
subsidies or other direct cash transfers, e.g., Richard Layard, Education Versus Cash Re-
distribution, $12 \mathrm{~J}$. Pub. Econ. 377 (1979). Nevertheless it is our assumption that, at least
among legal economists (that is, economists or economics-minded scholars who have ap-
pointments in law schools) there would be a consensus that, in fact, such policy tools as
cost-benefit analysis and education subsidies should be kept separate from redistributive
policy (that is, should be justified solely on efficiency grounds), with redistribution again
limited to the tax-and-transfer system. (As for precisely what we mean (or what the litera-
ture means) by the distinction between legal rules and tax-and-transfer rules, see Section
II.)

In addition, like most legal economists, it seems that most contemporary classical liberal philosophers - the architects of modern distributive justice theory-advocate redistributing exclusively through the tax-and-transfer system. See, e.g., John Rawls, A Theory of Justice 274-80 (1971). The argument seems to be that redistribution through a tax-andtransfer system is less restrictive of liberty and the ability to choose one's preferred path in life than are redistributive legal rules. See Ronald Dworkin, Law's Empire 276-312 (1986) [hereinafter Law's Empire] (arguing that the concern for other people's well-being is the responsibility of the government and not of the citizens in their daily transactions utilizing private property). For a critique of this sort of liberty-based defense of tax-and-transfer rules as the exclusive domain of redistributive policy, see Anthony T. Kronman, Contract Law and Distributive Justice, 89 Yale L.J. 472 (1980).

10 In this Article, although we do not adopt the welfarist framework that seems to underlie most of normative economic scholarship, including law and economics scholarship, we assume, as explained more fully in Section IV, that some differences in well-being will be of concern to redistribution-minded policymakers. We note, however, that the debate over the use of redistributive legal rules has been conducted largely in welfarist terms. E.g., Louis Kaplow \& Steven Shavell, Should Legal Rules Favor the Poor? Clarifying the Role of Legal Rules and the Income Tax in Redistributing Income, 29 J. Legal Stud. 821, 822-25 (2000) [hereinafter Legal Rules]; Kaplow \& Shavell, Legal System, note 5; Sanchirico, Efficiency Rationale, note 8; Chris William Sanchirico, Taxes Versus Legal Rules as Instruments for Equity: A More Equitable View, 29 J. Legal Stud. 797 (2000) [hereinafter Taxes]. As we argue below, we believe that our framework should be attractive to welfarists as well as nonwelfarist policy analysts. See text accompanying notes 261-70. Indeed, our entire framework can be recast in purely welfarist terms. 
agree that the ultimate target for a redistribution-minded policymaker should be differences in overall well-being, not merely differences in wealth or income. ${ }^{11}$ But those scholars nevertheless focus primarily on income or wealth as the relevant measure of or proxy for wellbeing. ${ }^{12}$ That is, they tend to focus on monetary measures of wellbeing to the exclusion of other, nonmonetary measures. ${ }^{13}$ Moreover, they never take a position regarding the best redistributive policy tool for nonincome-related measures of inequality of well-being, even though a comprehensive redistributive policy, even under the economists' welfarist approach, should be concerned about a broader range of inequalities of well-being.

In this Article we develop a general framework for choosing the optimal redistributive policy instrument or combination of redistributive policy instruments, whatever one's vision of distributive justice might be. There are many different approaches to evaluating questions of distributive justice and redistributive policy. From all of the various approaches, however, it is possible to separate out two types of questions: First, what is the appropriate equalisandum (the thing to equalize, or the thing to redistribute with respect to)? Second, assuming a given equalisandum, what limitations should be imposed on its redistribution? ${ }^{14}$ As to the first question, the "equality of what?"

11 For example, Kaplow and Shavell clearly understand that, from a welfarist perspective, to the extent that the distribution of resources is considered important, it is the distribution of overall well-being (and not just the distribution of income) that matters. See, e.g., Kaplow \& Shavell, Fairness II, note 1, at 30 ("[T]he distribution of income may matter to social welfare because it affects the distribution of well-being, and, under the welfare economic approach, social welfare may depend directly on how equally well-being is distributed among individuals."). Kaplow and Shavell, however, prefer to talk only in terms of income redistribution "for convenience" and because "much analysis of distributive issues refers to the distribution of income and because many redistributive policies operate through individuals' incomes." Id. at 28-20 n.25.

12 The economists' focus on money income typically is not an explicit assumption in their models, but rather is implicit in their analysis, which tends to treat income as the primary measure of differences in well-being. See, e.g., Joel Slemrod \& Jon Bakija, Taxing Ourselves: A Citizen's Guide to the Great Debate Over Tax Reform 51 (2d ed. 2000) ("There are two distinct aspects to the fairness of a tax system. The first, called 'vertical equity' by economists, concerns the appropriate tax burden on households of different levels of well-being. It is about how much tax should be paid by a family with $\$ 200,000$ of income, versus a family with $\$ 50,000$ of income, versus a family with $\$ 10,000$ of income.").

13 One important exception to the standard approach is Sanchirico's work on redistributive rules, discussed throughout this Article. As we discuss in greater detail below, see text accompanying notes 148-51, one of Sanchirico's main contributions, on which we build in this Article, is to show that there are other important proxies for well-being besides income or wealth. See generally Sanchirico, Efficiency Rationale, note 8; Sanchirico, Taxes, note 10.

14 Although we present these two questions as being independent of each other, we are aware that they are interrelated. Specifically, one can favor a specific equalisandum precisely because of the limitations it implies. Nevertheless, we find it methodologically useful to divide the issues in this way. 
question, political theorists have given a myriad of responses. ${ }^{15}$ For some the concern is solely with inequality of "welfare." 16 For others it is equality of "primary goods." 17 For others it is equality of "resources." 18 For others it is equality of "access to advantage" 19 or "opportunity for welfare" 20 or "capability to achieve functionings." 21 In fact, one of the main objectives of distributive justice theorists seems to be to define a single equalisandum that can capture all our intuitions about an egalitarian society. 22

In this Article we do not attempt to distinguish among these different, sometimes overlapping conceptions of what should be equalized. We aim instead to analyze the purely functional question of what would be the ideal redistributive policy instrument in various settings given some theory about what we want to redistribute. Under this approach, we need only adopt some fairly general and uncontroversial assumptions about society's main egalitarian intuitions and get on with our project. To that end, and to simplify the analysis and minimize controversies over alternative visions of the good, we assume that any redistributive policy should acknowledge that some types of differences in well-being are worth intervention, independent of the

15 The importance of the question, as Amartya Sen observes, lies in the fact that the judgement and measurement of inequality is dependent on the choice of the equalisandum. Further, "[e]quality in terms of one [equalisandum] may not coincide with equality in the scale of another. For example, equal opportunities can lead to very unequal incomes. Equal income can go with significant differences in wealth. Equal wealth can coexist with very unequal happiness. Equal happiness can go with widely divergent fulfilment of needs. Equal fulfilment of needs can be associated with very different freedoms of choice. And so on." Amartya Sen, Inequality Reexamined 2 (1992).

16 John E. Roemer, Equality of Resources Implies Equality of Welfare, 101 Q.J. Econ. 751 (1986) [hereinafter Equality].

17 Rawls, note 9, at 62-63, 92.

18 Ronald Dworkin, What Is Equality? Part I: Equality of Welfare, 10 Phil. \& Pub. Aff. 185 (1981); Ronald Dworkin, What Is Equality? Part II: Equality of Resources, 10 Phil. \& Pub. Aff. 283, 300-01 (1981) [hereinafter Equality of Resources] (including mental and physical capacity as resources).

${ }_{19}$ G.A. Cohen, On the Currency of Egalitarian Justice, 99 Ethics 906, 916 (1989).

${ }^{20}$ Richard J. Arneson, Equality and Equal Opportunity for Welfare, 56 Phil. Stud. 77, 77 (1989).

${ }^{21}$ Sen, note 15 , at $4,39-55$.

22 Although there is considerable disagreement among distributive justice theorists concerning the proper framework or vocabulary for analyzing issues of distributive justice, the theorists seem to share many of the same intuitions. For example, most would agree that an individual's inordinately expensive tastes or bigoted feelings toward certain groups should not be taken into account when making egalitarian calculations. Certain versions of welfarism include this approach. See, e.g., John C. Harsanyi, Problems With Act-Utilitarianism and With Malevolent Preferences, in Hare and Critics: Essays on Moral Thinking 89, 96-98 (Douglas Seanor \& N. Fotion eds., 1988) (arguing that certain preferences, even if entirely informed and rational, should be given no weight in the evaluation of social policy); see also Kenneth J. Arrow, Some Ordinalist-Utilitarian Notes on Rawls's Theory of Justice, in Kenneth J. Arrow, 1 Collected Papers of Kenneth J. Arrow, Social Choice and Justice 104 (1983). 
individuals' underlying resources. In a similar manner we assume that some differences in resources can justify redistributive intervention, irrespective of overall well-being. ${ }^{23}$ We also assume that not every inequality provides a justification for compulsory redistribution. For example, we generally do not consider differences (in well-being, opportunity for welfare, access to advantage, whatever) that stem from differences in physical attractiveness to be an appropriate justification for redistributive policy. ${ }^{24}$

As to the question of what limitations should be placed on redistributive policy with respect to a given equalisandum, here too we do not try to defend any particular theory. Rather, we simply make some assumptions that we believe will resonate with widely held intuitions. For example, we assume that government redistributive policy should not target inequalities (of well-being, resources, or whatever) that result from individuals' informed, voluntary choices. Thus, we assume that any redistributive policy should seek to equalize inequalities that are the result of individuals' differing initial endowments of talent, wealth, opportunities, and the like-differences that derive entirely from an individual's genes or from her unchosen social and environmental circumstances. ${ }^{25}$ In addition, we assume that redistributive policy should target inequalities of well-being that result from things that happen after an individual is born that affect the individual's wellbeing, such as a debilitating injury or illness that is not the direct prod-

${ }^{23}$ Thus we adopt a sort of mixed "resourcism" and welfarism approach to issues of distributive justice. We are by no means the first to adopt such an approach. See, e.g., Sen, note 15, at 12-38; Cohen, note 19, at 921 . To get a sense of the implications of such a mixed approach, consider Cohen's example of the allocation of wheelchairs to the disabled. Cohen, note 19, at 917-18. The example involves a person whose legs are paralyzed and who needs an expensive wheelchair to get around. Cohen argues that egalitarians will recommend giving him a chair before they ask about the welfare level to which the person's paralysis reduces him. The reason is that " $[w]$ hen compensating for disability, egalitarians do not immediately distinguish between the different amounts of misery induced by similar disabilities in people who have different (dis)utility functions. They propose compensation for the disability as such, and not, or not only, for its deleterious welfare effects." Id. (emphasis omitted). This is because "[l]ame people need [wheelchairs] to be adequately resourced, whether or not they also need them to be, or to be capable of being, happy." Id. at 918 .

${ }^{24}$ To rule out differences in physical appearance as a redistribution-worthy source of inequality may strike some as giving away too much. Of course, whenever one tries to draw distinctions between those types of inequality that deserve compulsory redistribution and those that do not, there will be an inevitable measure of recourse to one's own intuitions on the subject. And that is true here as well. We should emphasize that nothing essential in our functional analysis turns on our choices of assumptions regarding which types of inequality will justify redistribution.

${ }^{25}$ See generally Will Kymlicka, Contemporary Political Philosophy: An Introduction 75 (1990) ("People's fate should depend on their ambitions (in the broad sense of goals and projects about life), but should not depend on their natural and social endowments (the circumstances in which they pursue their ambitions)."). 
uct of the person's life choices. In sum, we assume for the purposes of this Article that redistributive policy should try to eliminate or reduce only those inequalities that are attributable to "brute luck." Or, to use Ronald Dworkin's terms, we assume that a redistributive policy should be "endowment-insensitive" but "ambition-sensitive," 26 and we seek to provide a framework for choosing the optimal redistributive policy instrument to achieve that goal.

For bona fide distributive justice theorists, our decision to focus on brute luck-based inequality of well-being without providing a full defense of that assumption will be controversial. Presumably, however, most of those who object will complain that our theory provides too narrow (too stingy) a justification for compulsory redistribution. That is, one might argue that the government also should try to redress some types of inequality that are not the result of pure brute luck. ${ }^{27}$ We do not necessarily disagree. We limit our analysis to brute luckbased inequality, however, because it seems relatively uncontroversial that compulsory redistribution can be justified at least with respect to brute-luck-based inequality. ${ }^{28}$ Moreover, focusing on brute-luckbased inequality responds to the legitimate efficiency concern of moral hazard inherent in any redistributive scheme-that is, the worry that the availability of redistributive transfers will distort incentives in various ways, such as by undermining work incentives. ${ }^{29}$

26 Dworkin, Equality of Resources, note 18, at 293, 330; see also Cohen, note 19, at 908 (arguing that "the primary egalitarian impulse is to extinguish the influence on distribution of both exploitation and brute luck"). Brute luck, as distinct from "option luck," arises when an individual's misfortune is involuntary and is not the result of a risk she could have avoided. Welfarists therefore should find the distinction between brute luck and option luck similar to issues associated with moral hazard. Thus, they too should find this distinction relevant. Our conception of brute luck is somewhat broader than Dworkin's, however. For us, brute luck arises when an individual's misfortune is not the result of a risk she reasonably could have avoided.

27 For example, some would argue that the focus on the brute luck/choice distinction is misguided, because it is nonexistent. Every choice, the argument goes, is the result of one's genetic, environmental, and social circumstances. See, e.g., John E. Roemer, Equality of Talent, 1 Econ. \& Phil. 151 (1985). On this view, what should be equalized is wellbeing defined generally. Roemer, Equality, note 16. By adopting brute luck-based inequality as our redistributive target, we obviously reject this extreme version of determinism. We adopt instead the view that individuals should be held responsible for (and left to live with) the results of at least some of their informed choices.

28 See Kymlicka, note 25.

29 In addition, some will object to our use of brute luck-based inequality because such a norm is impossible to apply. Every difference in well-being, the argument goes, is attributable to an unknowable mix of brute luck and choice. We do not underestimate the seriousness of this concern. Indeed, perhaps the most important and difficult task of the redistribution-minded policymaker is to develop reliable and, to the extent possible, precise ways of distinguishing the effects of individual choice from the effects of brute luck. In any event, these complaints are irrelevant to the main purpose of this Article. Although we explain our comparative advantage framework through the lens of a particular redistributive goal (reducing brute luck-based inequality), the framework at the most general 
Thus, our approach will be to assume that the policymaker ${ }^{30}$ has decided that some amount of redistribution is called for with respect to inequality of something, whether it is income, wealth, capabilities, or well-being. Which types of inequality should be so targeted and how much are questions that we leave unanswered. ${ }^{31}$ We focus on the institutional structures the policymaker should use to achieve whatever redistributive goals it has chosen?32

Our general conclusion is that the redistribution-minded policymaker should choose the system that has a comparative advantage at redistributing with respect to the particular type of redistribution at issue. If we focus for the moment on the dichotomous choice between legal rules and tax-and-transfer rules (as the literature has tended to do), we answer this question by asking two related but independent questions: First, which of the two systems is the "better observer" with respect to the type of inequality that is being targeted? (That is, which system has a comparative advantage at observing the characteristic with respect to which redistribution is desired?) Second, which system is the "better redistributor" with respect to that type of inequality? One major theme of our analysis is that, whereas one institution may have a comparative advantage at measuring the particular type of inequality at issue, another institution may have a comparative advantage at doing the actual redistributing. For example, in some situations we may want to use the legal system to observe the relevant

level could be applied to different conceptions of redistributive policy. We have tried, however, to choose a redistributive goal that is consistent with a wide range of theories of distributive justice.

30 We use the term policymaker as if there were a single decisionmaker whose decisions somehow reflected the democratic will of society-the proverbial benevolent dictator. Thus, for most of this Article, we ignore problems of preference aggregation or public choice concerns. We return to this point in the Conclusion.

${ }_{31}$ For most of this Article, we assume that a redistribution-minded policymaker would likely regard each type of inequality as being largely independent of the other types of inequality. Thus, for example, if it could be shown that the tax system is the optimal policy instrument for dealing with income inequality, then a policymaker that seeks to use a different policy instrument to redistribute with respect to, say, differences in genetically determined health prospects can ignore income differences. This assumption appears, on first blush, inconsistent with the standard assumption of welfarists that there is only one, unified criterion that the policymaker should care about (namely, individual well-being) and that whatever policy instrument is used to redistribute should take into account all available "proxies" for that unobservable characteristic. In Section IV, however, we argue that our independence is in fact consistent with the welfarist approach. See text accompanying notes $259-72$.

32 We realize that the choice of type and amount of redistribution may be linked to the functional question of which structure will be chosen to implement whatever redistributive policy is chosen. Our analysis assumes, however, that it is both conceptually possible and analytically useful to separate the institutional question (which we explore in this Article) from the substantive redistributive question (which we seek to avoid). 
type of inequality or proxies for inequality and then have the tax-andtransfer system make the redistributive transfer.

Which brings us to another major theme of our analysis: The two existing categories-legal rules and tax-and-transfer rules-do not exhaust the universe of redistributive policy instruments. Even if every policy instrument in some way could be characterized with some combination of those labels, it is not ultimately labels that we care about. It is institutional design. And our view, stated most generally, is that the policymaker should choose whatever institutional design works best for each type of targeted inequality. Nevertheless, it makes sense to begin the analysis with a look at the traditional categories; therefore, in Section II we provide a working definition of those terms.

Section III adopts the legal rule/tax rule dichotomy and focuses on the type of redistributive policy choice that has dominated the redistributive rules debate to date, that is, the question of income redistribution. Hence, if we assume that the policymaker has decided to engage in a given amount of income redistribution (say, from the rich to the poor), what is the best policy tool for achieving that goal?33 Applying our comparative advantage framework, we conclude that the tax-and-transfer system probably is in general better at observing or measuring individual income. After all, the tax system is designed largely, if not primarily, with that task in mind. We also conclude that the tax-and-transfer system is probably the better redistributor, for practical reasons having to do with the so-called "contracting around" and "haphazardness" problems associated with income-redistributive legal rules. Thus, with respect to dealing with income inequality, we generally side with those who believe that the lion's share of income redistribution should be done through the tax-and-transfer system, although there may be some relatively small, supplementary role for the legal system in redistributing income. We also show, however, that one of the primary justifications for never using legal rules to reduce income inequality - the so-called double distortion argument ${ }^{34}$-has been overstated. By the same token, however, we show that certain arguments that have been made to support always using legal rules to reduce income inequality ${ }^{35}$ also have been overstated.

Also in Section III, we examine some existing behavioralist justifications for using an income-redistributive "tort tax," such as a tort rule that requires "rich defendants" to pay a special income tax when held liable in court. Such a tort tax, some argue, might have some of

\footnotetext{
33 Although the literature focuses on income inequality, it is understood that most of the same arguments could be made with respect to inequality of wealth as well.

34 Kaplow \& Shavell, Legal Rules, note 10; Kaplow \& Shavell, Legal System, note 5.

35 Sanchirico, Efficiency Rationale, note 8; Sanchirico, Taxes, note 10.
} 
the desirable characteristics of a probabilistic income tax: In particular, such an implicit tax might have less of a distortive effect on work incentives than a standard direct income tax. ${ }^{36}$ Our analysis of the tort tax, however, suggests that, even if an income-redistributive tort rule were feasible, the presence of liability insurance would undermine its nondistortive character, making it more like a direct tax with one important difference: Liability insurance companies rather than the IRS would determine and collect the taxes. Thus, whether a supplementary tort tax would be desirable would depend, interestingly, on whether it would be desirable to have at least part of the income tax administered by private insurance companies rather than by a single administrative agency such as the Service. If one sees value in privatizing such government functions (in order to benefit from the effects of competition), a modest tort tax might be a useful adjunct to the existing tax system.

Whereas Section III analyzes the existing redistributive rules debate, and thus focuses on the problem of reducing income inequality, Section IV changes gears significantly. In Section IV, we take seriously the idea that there are other types of inequality that society might want to reduce via redistribution. (Or, to put the analysis in welfarist terms, there are other proxies for welfare inequality that society might want to take into account.) And it is with respect to nonincome sources of inequality (or nonincome proxies for well-being) that the tax-and-transfer system no longer has the clear comparative advantage. Indeed, we identify some examples in which the legal system arguably has an advantage over the tax system as a means of redistribution.

In Section IV, using an example from the field of insurance law, we explore how antidiscrimination rules can produce a sort of horizontal redistribution (cross-subsidization across consumers) that is not only feasible but arguably more efficient than the tax-and-transfer alternative. Section IV begins by asking whether a rule forbidding insurance companies from using certain types of genetic information in their underwriting decisions might result in a redistributive transfer (from the better off to the less well off) in a way that minimizes administrative costs. Here again, we compare the legal rule approach (which in this case takes the form of a nondiscrimination norm) to a tax-and-transfer alternative. What we show, however, is that the choice of the optimal redistributive policy instrument in this case is more complicated than a simple choice of legal rule versus tax rule. Instead, the best choice may lie somewhere between those two extremes. For example, one

36 Christine Jolls, Behavioral Economics Analysis of Redistributive Legal Rules, 51 Vand. L. Rev. 1653 (1998) [hereinafter Behavioral Economics]. 
intermediate solution might entail a contract-based legal rule forbidding insurance companies from discriminating on the basis of diseaserelated genes together with a law requiring the purchase of insurance.

Compulsory private insurance, of course, begins to resemble various social insurance alternatives, such as Medicare or Social Security, which in turn have some of the characteristics of a tax-and-transfer regime. That is, the distinction between premiums and taxes begins to break down, as does the distinction between benefit pay-outs and in kind transfers. As a result, the analysis in this Section-and the lessons from norms of nondiscrimination in private insurance marketsmay have important implications for the optimal design of social insurance arrangements. For example, it is worth exploring the extent to which cross-subsidization within Medicare (from the well to the sick) can be understood as a relatively efficient system of horizontal redistribution. In any event, our point in this Section is to shift the focus away from simple comparisons of the paradigmatic cases of legal rules and tax regimes to a more subtle discussion of mixed regimes, especially those involving various types of insurance mechanisms.

Section IV also analyzes two types of nonincome-based inequality that arguably can be reduced best via a tort rule. We explore the extent to which pain and suffering damages can be justified as a type of redistributive transfer from the better off (those who do not experience personal injuries) to the worse off (those who do). If such a redistributive transfer is something that society deems appropriate, we argue that the tort system has a comparative advantage with respect to making such transfers. We also consider a type of inequality that has been discussed in the existing redistributive rules literature: inequality with respect to an individual's "accident-proneness"-or the innate (in)ability to avoid accidents. For example, the aged or the disabled may have an inherently lower ability to avoid certain types of accidents. Or, to use the law and economics term, such individuals have "high costs of care." 37 If society determined that redistribution with respect to this sort of inequality were appropriate, how should it be done? Applying our comparative advantage framework, we explore the possibility of a negligence standard in which the due care standard is defined subjectively (based on each individual's own "cost of care") rather than objectively (based on the cost of care of the hypothetical reasonable person). We argue that a due care standard that is at least somewhat tailored to the individual's circumstances can be justified both on efficiency and distributive justice grounds.

37 Michael B. Dorff, Why Welfare Depends on Fairness, 75 S. Cal. L. Rev. 847, 889 (2002). 
In this Article, then, we show that in applying our comparative advantage framework, income redistribution may be best accomplished primarily through the tax-and-transfer system (with some possible room for a supplementary lump sum tort tax), but there are nonincome measures of inequality with respect to which the legal system should play an essential redistributive role. Although we provide a framework that we believe can be useful in analyzing any question of redistributive policy, we explore in detail only a limited set of applications, on the theory that we cannot do everything in one article. In particular, most of our applications involve cash transfers, and only certain types of cash transfers. ${ }^{38}$ The one important exception involves the example of horizontal redistribution in insurance markets, where a nondiscrimination rule with respect to genetically determined diseases would produce a sort of in kind redistribution - that is, redistribution in the form of medical care. Moreover, except for a brief discussion in the Conclusion, we overlook a whole range of other types of redistributive policies, including, most prominently, disability law, ${ }^{39}$ antidiscrimination law more generally (that is, beyond the context of insurance), as well as anything having to do with the scope of property rights. ${ }^{40}$ Although our comparative advantage framework may indeed apply in those areas as well, such an inquiry is beyond the scope of this Article.

\section{Defining Some Terms}

As mentioned in the Introduction, in applying our comparative advantage framework, we generally follow the convention within the

38 Although economists tend to favor cash transfers over in kind transfers, we believe that any comprehensive theory of distributive justice must take into account in kind transfers (such as regulating disabled individuals' access to public areas) as well antidiscrimination laws in general. The rationale behind the economists' preference for cash rather than in kind transfers is that cash is more fungible and thus permits transferees to have a greater degree of control over what the subsidy ultimately goes to pay for. Stiglitz, note 2, at 397400. For economists, it is almost always a good idea to let individuals decide what is in their own best interests. Even economists, however, will acknowledge some limits to this principle in cases in which there are good reasons to doubt that the transferees will make choices that are in their own long-run best interests. For example, even economists are willing to be paternalistic with children or with addicts of various sorts. Id. at 401-05. In addition, economists may accept in kind transfers if necessary to avoid externalities or if in kind transfers can be viewed as a sort of public good expenditures. As an example of the latter type of expenditure, it might make sense from an economist's perspective to install ramps in public places to accommodate individuals in wheelchairs if such ramps can be understood as a sort of public good.

${ }^{39}$ See generally Mark Kelman, Strategy or Principle? The Choice Between Regulation and Taxation (1999).

40 See, e.g., Hanoch Dagan, Takings and Distributive Justice, 85 Va. L. Rev. 741 (1999) [hereinafter Takings] (demonstrating how progressive distributive considerations can be grafted onto takings law without unduly hindering efficiency and other concerns). 
literature of using the terms tax-and-transfer system and legal system as if their meanings are clear and obviously distinct from each other. Of course, neither is true. One way of illustrating this point is to note that any legal rule could be recharacterized semantically as a sort of tax-and-transfer regime. For example, a tort liability rule can be recharacterized as a tax on tort defendants accompanied by an equal transfer to the tort plaintiff, with the administrator of the tax-andtransfer regime being the courts and, to some extent, private insurance companies.

But to recharacterize a tort rule in this way does not change the fact that a tort rule is in many important ways different in institutional design from, say, the income tax. In our view the choice faced by the redistribution-minded policymaker is not so much an either/or decision as a more general question of institutional design. ${ }^{41}$ Nevertheless, it still makes sense at least initially to focus (as the existing literature has done) on a few core examples that do fit rather nicely into these categories. It is also important, as mentioned in the Introduction, to understand and explore the other institutional designs available to the policymaker. To that end, one major objective of this Article is to begin to examine some of the intermediate redistributive policy options that lie somewhere between the extreme examples that have been the focus of the debate to date. For now, though, we explain what we (and others) generally mean by these dichotomous categories of tax-and-transfer system and legal system.

We begin with the tax-and-transfer system. A tax might be defined as money or other resources collected by the government from individuals or firms. ${ }^{42}$ Taxes typically are determined by applying a tax rate (or series of tax rates, in the case of a progressive tax) to a given base of a particular taxable unit. It is the taxable unit (individual or corporation) that is legally responsible to pay the taxes. Taxes usually are imposed for one of three reasons: (1) to raise revenue to spend on public goods such as national defense or a legal system, which, by assumption, the unregulated market cannot provide or cannot provide satisfactorily by itself, (2) to fund redistributive transfers either in cash or in kind from one group to another (usually from the better off to the less well off, or so we hope), or (3) to internalize externalities and

${ }^{41}$ Jon D. Hanson \& Kyle D. Logue, The Costs of Cigarettes: The Economic Case for Ex Post Incentive-Based Regulation, 107 Yale L.J. 1163 (1998). We are not the first to recognize the multifaceted nature of the choice that faces the redistribution-minded policymaker. See, e.g., Kelman, note 39.

42 Taxes also could take the form of in kind payments. For example, the military draft could be thought of as a type of tax for which payment must be made in the form of time devoted to military service. Richard A. Posner, Economic Analysis of Law 524 (5th ed. 1998). 
enhance efficiency. One can imagine taxes on a wide range of tax bases, from those as broad as income or consumption to those as narrow as sales of cigarettes.

On the transfer side, dollars raised through taxes can be spent in various ways. ${ }^{43}$ For example, they can be spent on public goods. Unless those public goods provide benefits to taxpayers precisely equal to (or in proportion to) the amount of tax they pay into the system, the provision of such public goods will effect some degree of redistribution. ${ }^{44}$ In addition, tax dollars can be transferred directly to the least well off in society either as cash subsidies or some type of in kind benefits. ${ }^{45}$ Thus, one cannot determine the overall distributional effect of a tax-and-transfer system by focusing solely on the tax side or exclusively on the transfer side. Both sides of the ledger must be taken into account. The paradigmatic example of a tax-and-transfer regime seems to be an income tax that includes a transfer component-that is, individuals whose annual income rises above a given amount pay taxes to the government, and those whose income falls below a given amount receive a transfer from the government. ${ }^{46}$ The latter part of the system sometimes is called a negative income tax.

The participants in the redistributive rules debate seem to use the term legal rules to mean such private law fields as tort law, contract law, and property law and such nontax public law fields as environmental law, product safety regulation, and labor law. ${ }^{47}$ Thus, legal rules are, essentially, all private law and all nontax public law. Specific examples of legal rules that have been characterized as redistributive, or potentially redistributive, include products liability rules making producers responsible for personal injuries caused by their products, ${ }^{48}$ consumer lending laws that limit the amount of interest that lenders can charge, ${ }^{49}$ minimum wage laws, ${ }^{50}$ and housing codes. ${ }^{51}$

43 Alternatively, in kind tax payments of, say, labor can be devoted to any number of public purposes such as military service.

44 Polinsky, note 5, at 120.

45 Kelman, note 39, at 103 . Such redistributive transfers themselves can be viewed as a sort of public good, in the sense that, without government compulsion, the same degree of redistribution from rich to poor could not be achieved.

46 See Kronman, note 9, at 498-99.

47 In his classic book, Polinsky includes such fields as nuisance law, contract law, automobile accident law, environmental law, and products liability law within his analysis of "legal rules." Polinsky, note 5.

48 See Alan O. Sykes, Reformulating Tort Reform, 56 U. Chi. L. Rev. 1153, 1159 (1989) (reviewing Peter W. Huber, Liability: The Legal Revolution and its Consequences (1988)); Gregory Keating, Distributive and Corrective Justice in the Tort Law of Accidents, 74 S. Cal. L. Rev. 193, 194 (2000) (arguing that concepts of distributive justice should inform tort law generally).

49 Kronman, note 9 , at 473 .

50 Id. 
With respect to some legal rules, the effect of the rules is to allocate risks between parties-between buyers and sellers, producers and consumers, drivers and pedestrians, polluters and the state. ${ }^{52}$ As a result, legal rules, private and public, often give rise to insurance markets, as individuals or firms seek to shed the risk associated with those rules. ${ }^{53}$ It makes sense, then, that if the full distributional effects of a redistributive legal rule are to be considered, the effects of the applicable liability insurance market - such as the price and terms of the standard liability policies-also should be considered. Although some participants in the redistributive rules debate have recognized this fact, ${ }^{54}$ we attempt to incorporate more fully into our general framework the role of liability insurance as part of the so-called legal system.

One other term that we should define at this point is "income." As other scholars writing in this literature have done, we focus on income as the primary measure of economic well-being and thus assume that income inequality is a primary target of any redistributive policy. ${ }^{55}$ Although for nontax experts, the meaning of the term income may seem obvious, any tax scholar, and any law student who has taken the introductory federal income tax course, knows otherwise. Giving flesh to the concept of income occupies a substantial fraction of the voluminous Code and even more voluminous regulations. Moreover, there is a large tax policy literature devoted to the question of what constitutes income. We do not expect to offer a comprehensive definition of income in this small space. We offer a tentative, functional definition to get things started, a definition shaped by the purpose of our analysis.

At the most general level, an individual's income can be understood as a proxy for the more salient but unobservable underlying characteristic of "ability to pay taxes." And this notion of ability to pay includes both the individual's human capital (that is, her earning power) and financial capital (for example, the return from her inherited wealth). We also define income to be roughly what the Code calls "adjusted gross income," which consists of an individual's wages and salary (income from human capital) as well as her rents, interest, and dividends received (income from financial capital) net of business-re-

${ }^{51}$ Bruce Ackerman, Regulating Slum Housing Markets on Behalf of the Poor: Of Housing Codes, Housing Subsidies and Income Redistribution Policy, 80 Yale. L.J. 1093 (1971).

52 Polinsky, note 5, at 132-33.

53 Id. at 53-55.

54 See, e.g., Jolls, Behavioral Economics, note 36, at 1663-67.

55 See note 5 . 
lated expenses. ${ }^{56}$ What the tax lawyer or tax scholar immediately will notice about this definition of income is its omission of certain deductions, such as those for extraordinary medical expenses and for casualty losses. We left those out intentionally, because whether to allow such deductions is a version of the question that this Article primarily addresses. That is, deductions for medical expenses or casualty losses should be allowed, under our framework, only if the income tax system is the optimal system for achieving distributional equity with respect to those characteristics.

\section{Income Redistribution: The Current Redistributive Rules Debate}

\section{A. Applying the Comparative Advantage Framework}

The question this Section addresses, and the question on which the literature has focused, is what redistributive policy instrument or mix of instruments is the best means of redistributing with respect to income inequality. Or to put the question in the spirit of the existing redistributive rules debate: Should redistribution with respect to income always be left exclusively to the tax-and-transfer system or is there some role for income redistribution through the legal system? In our view, two further questions facilitate the choice of the optimal redistributive policy instrument-especially when comparing legal rules to tax rules: (1) Which institution (the tax system or the legal system) is the "better observer," that is, which is better at measuring each individual's income? and (2) Which institution is the "better redistributor," that is, once we have the information about income, which system should make the actual transfers? Again, these functions could be performed by the same institution or by different institutions, and in some cases, by both.

\section{The Better Observer}

It seems uncontroversial that the income tax system would be a better observer than the legal system when it comes to measuring income. After all, the whole enforcement tax system (including the Code, the Service, and the like) was designed largely with that task in mind-to define the concept of income, to establish a set of tax rates that apply to different levels of income so as to assure the desired level of progressivity (or lack of it), and to set up a system of enforcement (including wage withholding, information returns, and the threat of audits) to induce the maximal level of compliance with the minimal

56 IRC $\S 62$. 
amount of enforcement costs. Even those who support some redistributive role for the legal system seem to assume that something like the existing income tax regime would remain in place, at least as a source of information about individuals' relative incomes. ${ }^{57}$

We do not claim that the existing income tax system is perfect or even nearly perfect. As far as we are aware, no one holds that view. All existing tax systems have flaws, and the U.S. system is no exception. Indeed, most tax policy scholarship is devoted to pointing out the many imperfections in existing tax regimes in this country and elsewhere. But the relevant comparison is between an idealized taxand-transfer system, after the flaws have been fixed (or minimized), and an idealized legal system, also devoid of flaws. Thus, the question we are interested in is which system, by its nature, would be the better proxy observer with respect to income. And again, if that is the question, the obvious answer seems to be the tax-and-transfer system. ${ }^{58}$

\section{The Better Redistributor}

The second part of our comparative advantage analysis requires the policymaker to ask whether the legal system or the tax-and-transfer

57 For example, even Sanchirico, who clearly sees some legitimate redistributive role for the legal system, never advocates outright abolition of the income tax. See generally Sanchirico, Efficiency Rationale, note 8.

58 One qualification to this conclusion might be that the legal system could provide a sort of back-up audit function to the income tax system. That is, even if we need to have something like the existing tax system as a means of gathering certain basic pieces of information about the vast majority of taxpayers' income levels, it might be useful if courts were to gather (and perhaps share with the Service) a more detailed picture of the wealth or income of the parties before it. The Service, for example, used to have a program called the Taxpayer Compliance Management Program ("TCMP"), whose purpose was to subject a small number of randomly-selected taxpayers to a very comprehensive audit, much more comprehensive than the general audits performed by the Service. The purpose of the TCMP audits was to produce information about taxpayer compliance behavior that could assist the Service in its enforcement efforts, including its decisions regarding where to focus its enforcement resources. Congress abolished the program in 1998. In an effort to measure compliance in a less burdensome manner, the Service plans to implement a new program known as the National Research Program ("NRP"), which also will review randomlyselected returns. See George Guttman, IRS Moving Ahead on Taxpayer Compliance Survey, 95 Tax Notes 833 (May 6, 2002) (describing the now-extinct TCMP as well as the NRP). One possible alternative or supplement to the TCMP would be to have courts, in nontax cases, perform a similar function as part of implementing a redistributive legal rule. This, if we imagine courts seeking to engage in some measure of income redistribution via, say, tort law, we might imagine the courts relying not merely on the parties' tax returns, but engaging in full scale audits. Giving courts this sort of in-depth audit responsibility might even be better than having the Service do it in cases in which, because of the nature of the lawsuits, information concerning the parties' financial situation is relevant for reasons independent of distributional policy. To be clear, we do not argue for replacing the tax system generally as a means of observing individual incomes, but rather argue for supplementing the tax system with the legal system. 
system is the better redistributor. The manner in which the tax-andtransfer system redistributes income is fairly straightforward: High income people are taxed more than low income people, with the lowestincome folks receiving transfer payments. For now, assume that something like our existing tax-and-transfer system will be used to gather information about each individual's income level. It is still conceivable that that information might be used by courts in various ways to equalize income between parties to lawsuits (or to equalize income between groups of parties who are likely to be involved in lawsuits). Income redistribution through the legal system could be accomplished in two general ways.

First, there could be "class-based" redistributive rules, which seem to be what some commentators have in mind when they talk about redistributive legal rules generally. ${ }^{59}$ Examples of these would include employment rules that are "pro-worker," property rules that are "protenant," or product liability rules that are "pro-consumer." The rationale behind such class-based redistributive rules would be that employees (vis-a-vis employers), tenants (vis-a-vis landlords), and consumers (vis-a-vis product manufacturers) are on average relatively poor. In all of these examples, the group being redistributed from is in a contractual relationship with the group being redistributed to, but that need not always be the case. One also could imagine "pro-pedestrian" auto safety rules or "pro-citizen" pollution control rules that did not involve contractual relationships. ${ }^{60}$ The theory behind any such rules, again, to the extent they are justified on income redistribution grounds, would be that one class of parties (employers, landlords, manufacturers, or drivers) tends on average to be wealthier or to have higher incomes than the class of parties benefiting from the rule.

An alternative to the class-based approach would be a "case-specific" income-redistributive legal rule. To see how such an approach would work, imagine a tort rule providing that if damages are awarded in any tort case they must be adjusted upward or downward depending on the relative incomes of the two parties involved in the suit.61 Thus, if in a particular driver-pedestrian auto accident case, the

59 See, e.g., Polinsky, note 5, at 124-27.

60 See id. at 123-24.

61 It is not always clear whether scholars writing about redistributive legal rules have in mind class-based redistributive rules or case-specific redistributive rules. See, e.g., Kaplow \& Shavell, Efficiency in Redistribution, note 10, at 669-70. On the one hand, when Kaplow and Shavell discuss the issue in general terms, they seem to deal with class-based redistributive rules. Yet, when providing models and examples, the rules Kaplow and Shavell discuss seem fairly case-specific, in that each individual subject to the rule is supposed to pay (or receive) tort damages in accordance with the difference between his and the other party's specific incomes. Id. Sanchirico, too, is somewhat hard to pin down on this point. In one place he seems to endorse case-specific redistributive rules. In his view, "specific 
injuring driver's income turned out to be higher than that of the injured pedestrian, the damages owed by the driver, if she were found liable, would be adjusted upward. Alternatively, if the pedestrian happened to be richer, the adjustment would go the other way; the damages would be reduced by the amount of the redistributive tax. Again, if such a rule were adopted, it is our assumption that the tax system would still be the primary proxy observer, in the sense that the courts, applying a class-based or case-specific income-redistributive rule, would use Service-gathered information regarding relative incomes. ${ }^{62}$

Return now to our second question: Which system - as between legal rules and tax rules-is overall the better income redistributor? As the literature on redistributive legal rules has developed, there seems to be little disagreement that the tax-and-transfer system should be used as one means of redistributing income, for the same reasons that it should be used as a proxy observer. The real question is whether there should be any income-redistributive role for the legal system. As summarized in the Introduction, the now conventional view among some economists and most law and economics scholars is that all redistribution of income should be done through the tax-and-transfer system, and none through the legal system. ${ }^{63}$

Commentators have offered three distinct arguments in support of this conclusion. First, it has long been argued that income redistribution through certain types of legal rules is not feasible, because the parties affected by the rule will contract around the redistributive aspect of the rule. ${ }^{64}$ A second longstanding argument against incomeredistributive legal rules is that, even to the extent such redistribution is feasible, it is too haphazard-it is both underinclusive and overinclusive-compared with the same sort of redistribution accomplished through the tax-and-transfer system. ${ }^{65}$ The third and most recent objection to income-redistributive legal rules, sometimes called the double-distortion argument, says that any income redistribution that feasibly can be accomplished through the legal system can be accom-

conditioning [of the redistributive legal rules] on the observable economic attributes of the particular parties before the court is actually welfare-improving." Sanchirico, Efficiency Rationale, note 8, at 1011. Elsewhere, however, he suggests that class-based rules are what he has in mind. For example, his discussion of the use of "multidimensional tax tables," discussed below at note 165 , might be understood as getting at a sort of class-based redistributive legal rule. Id. at 1027-28.

62 It is with respect to the case-specific approach, however, that the courts could perform a sort of random auditing function. See note 58 .

${ }^{63}$ See text accompanying notes $5-8$.

64 See, e.g., Polinsky, note 5, at 122-23.

65 Id. at 125-27; Kaplow \& Shavell, Legal System, note 5, at 674-75; Sanchirico, Efficiency Rationale, note 8, at 1051-56. 
plished more efficiently through the tax-and-transfer system, because the redistributive legal rules inevitably involve two types of distortion whereas redistributive tax-and-transfer rules involve only one. ${ }^{66}$

In the following Subsections, we address these objections to income-redistributive legal rules. We argue that the legal economists' case for the exclusive use of the tax-and-transfer system for redistributing income and for never using income-redistributive legal rules has been overstated in several respects. In addition, we evaluate an argument that has been made in favor of always using legal rules to redistribute income at least as a supplement to the tax system. We conclude that this argument also is overstated. Our tentative overall conclusion with respect to income redistribution is that we agree with the legal economists' bottom line that the tax system should be the primary redistributive policy instrument, although for purely pragmatic (nontheoretical) reasons.

\section{B. Evaluation of the Case for Never Using Income-Redistributive Legal Rules}

\section{The Contracting-Around Argument}

A standard argument made by legal economists against using legal rules as a tool for redistributing income is that, in a large class of cases, redistributive legal rules simply will not work. Specifically, the argument is that, with respect to legal rules that govern parties who are in contractual relationships with one another, any attempt to redistribute income through the legal rule in some sense will be contracted around.67 Thus, although the critics of redistributive legal rules will concede that income redistribution is feasible (though nonoptimal) for legal rules governing strangers, such as drivers and pedestrians or polluters and pollutees, they generally agree that redistribution with respect to contract-based legal rules is not feasible, whether the contractual relationship in question involves a bilateral monopoly, with the two parties bargaining over the surplus, or a competitive market situation, with prices and terms determined by market forces. ${ }^{68}$ In either case, if the policymaker were to use a legal rule to redistribute from one group perceived to be relatively wealthy to another group perceived to be relatively poor, the redistributive aspect of the rule would be offset.

The way this contracting-around process would work depends on the market setting in which the rule was designed to operate. First,

${ }^{66}$ Kaplow \& Shavell, Legal Rules, note 10, at 823-24.

67 See, e.g., Polinsky, note 5, at 122-23.

68 See, e.g., id. at 122-24. 
consider situations involving bilateral monopoly contractual relationships, for example certain landlord-tenant relationships. If a pro-tenant redistributive rule were introduced into such a setting, the parties would simply undo the effects of the rule through ex ante bargaining over price or terms or both. The result would be that the joint surplus from the contractual relationship would be distributed between the parties according to their relative bargaining power. ${ }^{69}$ And since the superior bargaining power often would rest with the wealthier party, it is doubtful that the resulting distribution of the contractual surplus would be consistent with the redistributive aim of the policymaker.

Second, consider contractual situations that do not involve bilateral monopolies but that instead arise under conditions of market competition. In such settings parties would not literally contract around the redistributive rule; rather, competitive forces in the long run would cause prices and terms to adjust in a way that would offset the intent of the rule. ${ }^{70}$ For example, if a special products liability "tax" were adopted in order to redistribute from relatively rich manufacturers to relatively poor consumers, the long-run outcome would be that the prices would rise to offset the effect of the rule. ${ }^{71}$ For this reason, the conventional law and economics version of the contracting-around argument concludes that "whenever the parties to a dispute are in some kind of contractual or market relationship, it may be difficult, if not impossible, to use the legal system to redistribute income."72

These simple versions of the contracting-around argument, however, are at best incomplete. For starters, in bilateral monopoly situations, although bargaining can undercut the distributional objectives of a redistributive legal rule, the design of rules can affect the division of the contract surplus. Indeed, some legal rules are designed specifically to alter the division of the surplus in contractual settings. Consider, for example, the rules enabling the creation of employee unions, authorizing collective bargaining, and permitting workers to go on strike. The very purpose of such rules is to change the division of the contractual surplus and to shift some of the contractual surplus-some of the wealth created by employment contracts-from employers to employees. ${ }^{73}$

\footnotetext{
69 Id. at $122-23$.

70 Id. at 123.

71 Id.; Kaplow \& Shavell, Legal System, note 5, at 1.

72 Polinsky, note 44, at 123.

73 We do not suggest, of course, that the rules authorizing collective bargaining are necessarily efficient. Our point here is that such rules are, in an important sense, redistributive. Sanchirico makes a similar observation. Sanchirico, Efficiency Rationale, note 8, at 1047. For an analysis of wage data from the early 1900's that shows that employers were able to pass on to their employees a significant part of the higher costs of higher postaccident compensation, but that the size of the wage offset was smaller for union workers,
} 
In addition, even in nonbilateral monopoly situations, the argument that prices always will rise to offset any redistributive effect of legal rules is an oversimplification. To the contrary, some scholars have argued that whether legal rules can be made to redistribute from, say, manufacturers to consumers depends on whether manufacturers are able to pass on the entire amount of the cost increase to the consumers. ${ }^{74}$ According to this argument, the extent to which manufacturers will be able to pass on those costs depends on the relative elasticity of demand and supply: The more inelastic the demand for and the more elastic the supply of the product, the more manufacturers will be able to pass on the costs to consumers. Following this reasoning, if demand for the product is elastic and supply inelastic, manufacturers would be relatively unable to pass those costs on to consumers. As a result, consumers may benefit from the redistributive legal rule because they get the full benefit of the rule but bear only part of the costs. ${ }^{75}$

Even this argument, however, is oversimplified. As Richard Craswell has pointed out, this argument ignores the fact that introducing a pro-consumer products liability rule not only would increase manufacturers' costs but also would increase consumers' demand for the product in question. Once the shift in demand is taken into account, the analysis becomes considerably more complex. ${ }^{76}$ In situations involving homogeneous consumer preferences regarding a new pro-consumer rule, Craswell shows that consumers will be made better off only if the rule is efficient-in the sense that consumers benefit from the rule more than it costs manufacturers. ${ }^{77}$ In a more recent analysis, Christine Jolls reached a similar conclusion with respect to "accommodation mandates," which she defines as a "requirement that employ-

see Price V. Fishback and Shawn Everett Kantor, Did Workers Pay for the Passage of Workers' Compensation Laws?, at http://papers.ssrn.com/paper.taf?abstract_id=226547 (Dec. 1994). One might hold the view, of course, that rules enabling the organization of labor unions and authorizing strikes are inefficient. Whether or not that is so is irrelevant to our argument here, since the question we address is not whether redistribution through contract-based rules is efficient, but whether it is feasible.

74 The observation that costs imposed through a contract-based redistributive rule might not be fully passed on through the price was first made by Bruce Ackerman in discussing housing codes. Ackerman, note 51, at 1105-08.

75 For a clear summary of this argument, see Richard Craswell, Passing on the Costs of Legal Rules: Efficiency and Distribution in Buyer-Seller Relationships, 43 Stan. L. Rev. 361, 366-68 (1991).

76 Id. at 368 .

77 Id. at 372. Craswell points out therefore that, under the homogeneous consumer assumption, pro-consumer rules that pass on less than all of the manufacturer's costs to consumers will make consumers worse off. In fact, the best situation for consumers is a rule that allows "more than 100 percent" of the costs to be passed on to consumers, in the sense that consumers benefit from the rule by more than it costs manufacturers. Id. 
ers take special steps in response to the distinctive needs of particular, identifiable demographic groups of workers."78

In other words, rules designed to be vertically redistributive in the contract-based setting can be so only if they are also efficient. In our view, although that conclusion is correct (under the assumptions), it is not clear what implications follow from it. One response would be to say that, if a pro-consumer or pro-employee rule is efficient, manufacturers or employers already will have incentives to adopt it (to maximize their profits), and we thus do not need a legal rule to force them to do so. One of the main points of this Article is to disagree with that assertion. Surely it is not the case that concluding that a rule is efficient (that the value to the employee or consumer exceeds the cost to the employer or manufacturer) negates the rule's independent value as a tool of distributive justice. Much of law and economics scholarship is devoted to analyzing market failures (or cognitive biases) that prevent parties from reaching efficient bargains. And if a pro-consumer or pro-employee rule, which for market failure reasons has not been adopted, can be supported both on efficiency grounds and distributional grounds, the case for adopting such a rule is clearly strengthened.79 As we argue at length in Section IV below, there are a number of instances in which a rule can be both efficient and redistributive in a desirable direction.

Moving beyond the assumption of homogenous consumers, in situations in which consumers have heterogeneous preferences regarding a particular pro-consumer rule, Craswell shows that distributional and

78 Christine Jolls, Accommodation Mandates, 53 Stan. L. Rev. 223, 231 (2000). The paradigmatic accommodation mandate would be the "reasonable accommodations" requirement of the Americans With Disabilities Act. Id. at 225. Jolls concludes that, if related antidiscrimination law is binding (that is, employers are not allowed to undermine the accommodation mandate by the reducing wages or employment levels of the targeted group), then an accommodation mandate will make the targeted group better off only if the value of the mandate to the group exceeds its cost to the employer. Id. at 246-51.

79 To take just one example, economist Jonathon Gruber studied the labor market effects of introducing mandatory coverage for the expenses of childbirth in employer-provided health insurance policies. According to traditional economic theory, the introduction of such a mandatory, not-bargained-for term in the employment contract should cause wages to fall by less than the cost of the benefit, because if wages fall by $100 \%$ of the cost of the benefit, then at least some of the employers would have provided the benefit voluntarily. The study found consistently, however, that $100 \%$ of the costs were shifted to employees through wage reductions and that there was virtually no reduction in employment. Presumably, although the employees valued the benefit more than its cost to the employer, the benefit was not being provided absent the mandate. Jonathon Gruber, The Incidence of Mandated Maternity Benefits, 84 Am. Econ. Rev. 622 (1994); see also Christine Jolls, Cass R. Sunstein \& Richard Thaler, A Behavioral Approach to Law and Economics, 50 Stan. L. Rev. 1471, 1506-07 (1998) (discussing Gruber study and suggesting a behavioral explanation for lack of market provision of apparently efficient term). 
efficiency concerns no longer necessarily converge and even defining what is a pro-consumer rule becomes very complex. ${ }^{80}$ Depending upon various consumer groups' willingness to pay for the product in question and for the new pro-consumer rule, it is possible to conceive of a situation in which a pro-consumer rule would result in a desirable form of "horizontal redistribution" (from one consumer group to another, rather than from manufacturer to consumer). ${ }^{81}$ Such a rule would be very difficult to design, however, if the redistributive target is income inequality among various consumer groups. ${ }^{82}$

In sum, it is wrong to assert that redistribution through contractbased legal rules is impossible or infeasible. Contract-based income redistribution can be accomplished under certain conditions. ${ }^{83}$ Nevertheless, the difficulties raised by the contracting-around problem are real. And as always, we are asking a comparative question: Given that in some cases redistributive legal rules to some extent will be contracted around, is not the tax-and-transfer system a superior system of redistribution? Although we remain tentative on this point, we conclude that the contracting-around argument seriously weakens the case for using contract-based legal rules to redistribute vertically, such as from manufacturers to consumers or from employers to employees in order to reduce income inequality. ${ }^{84}$ As we argue in Section IV,

80 Craswell, note 75 , at $376-77$.

81 Id.

82 Id. at 376-85. In Section III we offer several examples of contract-based redistributive legal rules that, in fact, do produce a type of horizontal redistribution that is both desirable and practical. Those rules, however, focus on nonincome measures of inequality. With respect to income inequality, we tend to agree with Craswell that contract-based redistributive legal rules-whether intended to produce vertical or horizontal income redistribution-are impractical, when compared with the tax-and-transfer system.

83 In this Article, we focus on redistribution in the form of cash payments. If we were to expand the analysis, however, to consider in kind redistributive transfers, there are examples of contract-based redistributive rules that would not be fully contracted around. For example, if the policymaker were to impose large fixed expenditures on employers or manufacturers designed to benefit relatively poor (or, more generally, less well off) employees or consumers, the cost of those fixed expenses could not readily be passed on to employees (through lower wages) or to consumers (through higher prices), as those are not marginal expenditures.

84 Sanchirico, in his response to the contracting-around argument, contends that that this argument does not provide a reason to prefer the income tax to redistributive, contract-based legal rules, because, among other things, the contracting-around problem is no different from the problem of income shifting, which plagues the tax-and-transfer system. Sanchirico, Efficiency Rationale, note 8, at 1047. Examples of income shifting include situations in which high-tax individuals shift their income (at least the reporting of it) to lowtax individuals within their families, thus lowering the household's overall tax burden and undermining the intended effect of the progressive rate structure. Id. at $1047 \mathrm{n} .113$. But income shifting of this sort would be just as much a problem for income-redistributive legal rules as it is for the direct tax on income. Under either system, special rules would be necessary to prevent this sort of tax evasion. Perhaps the more relevant question is whether something akin to the contracting-around problem would affect a direct tax on 
however, when we broaden the analysis to include nonincome measures of well-being, and begin to consider the possibility of using contract-based legal rules to redistribute horizontally (through crosssubsidization), the contracting-around argument has little or no application.

\section{The Haphazardness Argument}

Commentators also commonly argue that income redistribution through the legal system is more haphazard than income redistribution through the tax system. This haphazardness complaint consists of two separate concerns: the problem of inaccuracy and the problem of underinclusiveness. ${ }^{85}$

\section{a. The Problem of Inaccuracy}

The problem of inaccuracy is most acute with respect to class-based redistributive rules, by which we mean, again, legal rules designed to redistribute from a class of potential defendants to a class of potential plaintiffs based on a determination that the average income of the former class is greater than the average income of the latter. Examples of class-based redistributive rules might include pro-consumer product liability doctrines or pro-tenant property doctrines. There inevitably will be some imprecision within the relevant classes. For example, pro-pedestrian auto accident tort rules (that is, rules that tended to redistribute from drivers to pedestrians) would be a highly imprecise redistributive tool. As Polinsky notes, "[i]t may be that higher income persons are more likely to be drivers than pedestrians, but certainly there are many low-income drivers and high-income pedestrians." 86 As a result of such inaccuracy, pro-pedestrian rules would result in not only redistribution in the right direction (from rich drivers to poor pedestrians), but also a great deal of redistribution in the wrong direction (from poor drivers to rich pedestrians).

Not every class-based redistributive rule, though, need be so imprecise. Some classes of potential defendants and potential plaintiffs will

\footnotetext{
income. Tax policy scholars generally assume that the incidence of direct taxes on individual income tends not to be shifted through contractual relationships. See, e.g., Slemrod \& Bakija, note 12, at 71 ("The entire burden of individual income taxes is assumed to fall on those families who have the legal liability, with no shifting at all of tax levied on either labor or capital income."). The incidence of the corporate income tax is less clear. Id. at 68 ("Unfortunately, tracing the ultimate incidence of a tax levied on corporations, such as the corporation income tax, is a very difficult and controversial matter.").

85 Polinsky, note 5, at 125-27; Kaplow \& Shavell, Legal System, note 5, at 674-75; Sanchirico, Efficiency Rationale, note 8, at 1051-56.

86 Polinsky, note 5, at 126.
} 
correspond more closely with the income classes that are the target of redistribution. Some pollution control laws, for example, might be targeted at manufacturers (or, even more precisely, at manufacturers in certain industries) whose incomes are relatively high. So long as the benefits of such targeted redistributive rules either were focused on the relatively poor or spread evenly across the citizenry, such targeted class-based redistributive rules could be relatively accurate. ${ }^{87}$

Critics of class-based redistributive rules, however, argue that no matter how carefully the classes of potential defendants and potential plaintiffs are drawn, redistributive rules by their nature can never be as accurate as the income tax..$^{88}$ The income tax, after all, is designed primarily to separate individuals and firms into classes based on income. The main point of the Code is to provide a system for measuring and taxing the income of individuals and firms so that the amount of tax each taxpayer pays is an explicit function (a simple percentage) of that taxpayer's income. Thus, the Code, as well as the regulations and judicial decisions interpreting it, define in excruciating detail all of the items that must be included and that may be left out of the income tax base and the tax rates that apply to that base for each individual and firm. It is almost impossible to imagine that any class of potential defendants or potential plaintiffs could be drawn so narrowly as to approximate this level of accuracy of income measurement.

At this point in the debate, one might argue that the income tax is rife with "loopholes," provisions in the Code that permit exclusions or deductions for amounts that a "pure" or "ideal" income tax would include in the tax base or gaps in enforcement due to poor system design or lack of funding. Therefore, the argument goes, the income tax is not as accurate as critics of redistributive legal rules would have us believe and hence should not be held up as a perfect redistributive tool. The implication of this argument is that redistributive rules do not fair so badly by comparison. In our view, this response to the inaccuracy critique makes an important contribution: It emphasizes that the issue in this debate is always one of comparison, of relative costs and benefits of alternative redistributive policy instruments. Therefore, it is never enough to say simply that redistributive legal rules are lacking in some respect, rather they must be lacking relative to the tax system equivalent. The accuracy critique of redistributive

87 Polinsky makes a similar observation. Id. at 125-27. Of course, there is an enormous tax-incidence problem associated with this sort of redistributive rule. Even assuming that the owners of capital rather than employees or customers would bear the incidence of such a tort tax, many corporate shareholders (even shareholders in polluting manufacturers) are middle- or low-income individuals. See id. (discussing a similar problem in the auto accident context).

88 See, e.g., id. at 126-27. 
legal rules, however, given a fair reading, does contain a comparative argument. The claim is not that the income tax is perfect. Rather, the claim is that, because the income tax is specifically designed to do directly and precisely what legal rules can do only indirectly and derivatively, the income tax almost certainly will redistribute more accurately than will a class-based redistributive rule.

To see the force of this point, consider the following question: If class-based redistributive rules are to be used, how will the social planner (the designer of the rules) determine the accuracy of the classes in the first place? Presumably, by using some system akin to, or identical to, the income tax. That is, the policymaker would need some system for actually measuring the income of individuals and firms (defining income in some way) in order to be sure that, when using a redistributive legal rule, the classes of potential defendants and potential plaintiffs provide an acceptably accurate set of redistributive classes. And whatever income measurement system the policymaker sets up will be subject to the same sorts of complaints (regarding loopholes and the like) levied against the existing income tax. Thus, complaints that the existing income tax has too many loopholes or that it has large enforcement gaps may be persuasive in arguments concerning tax reform, but they are generally unpersuasive as a response to the accuracy critique of class-based redistributive legal rules.

The accuracy critique, however, has less (though not zero) force when applied to a case-specific approach to redistributive legal rules. To see how a case-specific approach would work, imagine a tort rule providing that, if damages are awarded in any tort case, they must be adjusted upward or downward depending on the relative incomes of the two parties to the suit. Thus, if in a particular driver-pedestrian auto accident case the injuring driver's income were greater than the injured pedestrian's income, the damages owed by the driver, if she were found liable, would be adjusted upward by some percentage of the difference. Alternatively, if the pedestrian happened to be richer, the adjustment would go the other way; the amount of the redistributive tax would reduce the damages. Under this approach, the redistributive legal rule would provide the same degree of accuracy as the income tax because the same measure of income, even the same tax forms, would be used. Thus, to the extent the income tax is inaccurate in measuring income, the same inaccuracy would show up in the casespecific redistributive rule. But there would be no additional inaccuracy of the sort inherently found in the class-based redistributive rule.

In fact, one can imagine a case-specific redistributive approach that would be more accurate than the existing income tax, at least with 
respect to the parties before the court. For example, a court applying a case-specific redistributive rule would perform either an auditing function (by looking beyond the returns to the parties' underlying records) or an income-averaging function (by looking at returns from more than one year). Either of those steps, however, would come at considerable additional administrative cost, and the question again would be: Why would such an auditing or income-averaging function be performed more efficiently through the legal system than through the tax system? It is at least plausible that there may be some efficiencies to having the legal system perform these functions as a supplement to the tax system. After all, the parties are before the court anyway and, at least for some types of litigation, already have reasons to open their books to the court. But these are empirical questions.

\section{b. The Problem of Underinclusiveness}

No matter how precisely a redistributive legal rule is drawn, whether class-based or case-specific, redistribution through the legal system inevitably would leave out some parties who, according to this argument, ideally should be included: namely, those who are not involved in litigation. In other words, ignoring the effect of insurance markets for the moment, the redistributive capacity of the legal system is inherently limited to plaintiffs and defendants or to whoever is the subject of the legal rule. Thus, although a targeted redistributive tort rule or pollution control rule could redistribute from some rich manufacturers to some less-rich consumers, there would be other high-income manufacturers untaxed and many low-income individuals who do not benefit from this rule. ${ }^{89}$ Even under the case-specific approach, redistribution would occur only from the rich to the poor who happen to end up in litigation against each other. The income tax, by contrast, enables the policymaker to transfer, in theory, from all rich within the taxing jurisdiction to all poor within that jurisdiction. Thus, the income tax is a more comprehensive-or less underinclusive-redistributive policy tool than the legal system is. ${ }^{90}$

First, we should point out that the most extreme version of the underinclusiveness argument is wrong. That is, the redistributive reach of a redistributive legal rule is not limited to parties who end up in litigation. It is a bedrock assumption of the standard economic analysis of tort law that tort doctrine (including any redistributive aspect of tort doctrine, such as a special tort tax on the rich) not only affects actual tortfeasors and victims but also changes the ex ante incentives

89 Polinsky, note 5, at 126.

90 Kaplow \& Shavell, Legal Rules, note 10, at 823. 
of all parties who are potential injurers and potential victims (that is, everyone who might possibly wind up in litigation governed by a redistributive rule). ${ }^{91}$ It is this ex ante incentive effect that often is described as the deterrence function of tort law.92 As a result, if a special tort tax were imposed on high-income tortfeasors, the ex ante effect would be that all high-income potential tortfeasors (those within the scope of the rule) would alter their ex ante conduct. ${ }^{93}$ For example, they would make additional investments in accident avoidance, or they would reduce the frequency with which they engage in the activity in question. This change in conduct-even if the potential injurers never actually end up in court-is a redistributive transfer of a sort. That is, only the relatively high-income members of the class of potential injurers will be induced to make those additional care-level investments or those activity-level reductions; and the resulting reduction in expected accident costs would benefit both high income and low income alike.

Still, although the most extreme version of the underinclusiveness argument is wrong, there is some degree of underinclusiveness. Even under the assumptions of the standard deterrence models, the incomeredistributive tort rule just described would reach only high-income tortfeasors. Some high-income folks, therefore, would not be included within the scope of the redistributive policy. ${ }^{94}$ With respect to this version of the underinclusiveness complaint, there are three responses.

First, Sanchirico has argued that, if policymakers added a redistributive component to every aspect of the legal system, redistribution through the legal system would be no less comprehensive than redistribution through the tax system..$^{95}$ The legal system, as defined in this literature, includes all nontax laws, both private and public. Thus, if tort rules, contract rules, property rules, as well as environmental and product safety regulations had a redistributive element, the under-inclusiveness complaint would weaken somewhat. It would not disappear, however, because, as we discussed in the previous Section, redistribution through many legal rules-namely contract-based legal

91 Steven Shavell, On Liability and Insurance, 13 Bell J. Econ. 120-21 (1982).

92 Gary T. Schwartz, Reality in the Economic Analysis of Tort Law: Does Tort Law Really Deter?, 42 UCLA L. Rev. 377 (1994).

93 Kaplow \& Shavell, Legal System, note 5, at 669.

94 More precisely, the application of the income-redistributive tort rule would be a function of not only of one's income but also of the probability of being involved in a tort suit. Thus, for example, high-income individuals who face a high probability of suit would face a larger tort tax than would high-income individuals who face a low probability of suit. At the limit, those high-income individuals who face no risk of tort liability (whoever that might be) would not be subject to the probabilistic tort tax at all.

95 Sanchirico, Efficiency Rationale, note 8, at 1052. 
rules-is at best highly speculative, owing to the contracting-around phenomenon. With that qualification, the basic point is sound, if somewhat self-evident: The more legal rules that are made redistributive, the more comprehensive the system of redistributive legal rules will be. ${ }^{96}$

The second response to the more modest underinclusiveness complaint involves the necessary relationship between legal rules and insurance markets. The presence of insurance markets clearly reduces the force of the underinclusiveness complaint. ${ }^{97}$ Insofar as potential plaintiffs and potential defendants have insurance coverage for the types of losses that can give rise to legal disputes, insurance premiums would adjust to reflect any redistributive component inserted in the applicable legal rule.

How precisely this would work would depend on the design of the redistributive legal rule. Thus, consider for example a class-based, redistributive pollution control law designed to burden relatively rich polluting corporations and benefit relatively poor communities. To the extent those polluters purchase liability insurance that covers them against the cost of such laws, their insurance premiums would reflect not only the risk of harm that their conduct poses to the community but also the additional redistributive tax that the court would impose in the event of liability. At the same time, some members of the community who benefit under this rule would purchase first-party property insurance that covered them against the risk of harm to them and to their property caused by environmental pollution. For those potential plaintiffs (or beneficiaries of regulation), their first-party insurance premiums would go down to reflect the higher amount that could be recovered (by them and by their first-party insurers via subrogation suits) from the polluters and the polluters' liability insurers.

Under this argument, then, the underinclusiveness complaint reduces largely (though not entirely) to a problem of underinsurance. That is, those individuals and firms who do not own insurance, in a sense, would not be included in the system of redistributive rules, unless they happened to end up in a lawsuit.98 There are two general types of solutions to problems of underinsurance. One is to make insurance more attractive by subsidizing it. That would be sort of a taxand-transfer approach to dealing with the problem. The other ap-

\footnotetext{
96 Id.

97 Polinksy, note 5, at $126 \mathrm{n} .83$ (observing that the underinclusiveness problem "may not be fully applicable" in situations where the potential plaintiffs have first-party insurance and potential defendants have liability insurance that would cover the loss in question. Thus, he concludes that the point of his underinclusiveness example "would apply only to the extent that the insurance coverage is incomplete.").

98 See id.
} 
proach would make insurance compulsory. If the parties did not purchase the coverage, they would not be allowed to engage in some activity. For example, the policymaker could require that manufacturers who wish to engage in certain pollution-emitting activities must first purchase a certain amount of liability insurance coverage.

A final response to the underinclusiveness complaint is to dismiss it. That is, if one is not arguing for replacing the income tax with a system of income-redistributive legal rules, but instead is calling for income-redistributive legal rules only to supplement the more comprehensive tax-and-transfer system, the underinclusiveness argument (by itself) has relatively little force. Put differently, if it could be shown that income redistribution on occasion can be done at least as efficiently through the legal system as through the tax-and-transfer system (that is, it can be shown that the tax-and-transfer system does not have a comparative advantage), it is not clear why underinclusiveness should be a concern..$^{99}$

\section{The Pareto-Superiority Argument}

\section{a. Kaplow and Shavell's Contribution to the Redistributive Rules Debate: the Double-Distortion Problem}

In an article published in 1994, Louis Kaplow and Steven Shavell make an argument that, on first blush, seems to end the redistributive rules debate once and for all, at least with respect to income-redistributive legal rules. Specifically, Kaplow and Shavell argue that legal rules should never be used to redistribute income, irrespective of the contracting-around and haphazardness complaints. ${ }^{100}$ The argument has several steps. First, they note that a tax on income or wealth will distort work incentives, in the sense that individuals under an income tax tend to work less than in a no-tax world. ${ }^{101}$ If legal rules are set to achieve efficiency only (and therefore are not designed to be redistributive), the work distortion associated with the income tax will be the

99 For a similar argument, see Dagan, Takings, note 40 , at 788-89 (arguing that avoiding certain discrepancies from an ideal distribution does not justify increasing disparities between the better off and the worse off).

100 Kaplow and Shavell note, however, that the contracting-around and haphazardness arguments do provide additional reasons to prefer the tax-and-transfer approach to redistributing income. Kaplow \& Shavell, Legal System, note 5, at 674-75. The basic insight of the Kaplow and Shavell arguments was made first in Steven Shavell, A Note on Efficiency vs. Distributional Equity in Legal Rulemaking: Should Distributional Equity Matter Given Optimal Income Taxation?, 71 Am. Econ. Rev. 414, 414 (1981), and a similar point was made in Aanund Hylland \& Richard Zeckhauser, Distributional Objectives Should Affect Taxes But Not Program Choice or Design, 81 Scand. J. Econ. 264, 264 (1979).

101 Kaplow \& Shavell, Efficiency in Redistribution, note 10, at 667-68. 
only distortion. ${ }^{102}$ By contrast, if instead of using the tax-and-transfer system to redistribute income, legal rules are designed to diverge from efficiency in a way that provides the desired amount of redistribution, there will be two distortions: the same work distortion that would occur under an income tax plus the distortion of the activity regulated by the (now inefficient) legal rule. ${ }^{103}$

Which leads to the final step: Because there is no reason to expect that these two distortions offset each other, it seems reasonable to conclude that two distortions are worse than one from an economist's perspective. ${ }^{104}$ This part of the Kaplow and Shavell thesis has been called the "double distortion argument." 105 In addition, in their more formal analysis, Kaplow and Shavell demonstrate that, under certain assumptions, it is possible with respect to any income-redistributive legal rule to design an alternative legal regime that is independent of income and that leaves everyone as well off as under the income-redistributive rule, but that also produces additional revenue for the government. ${ }^{106}$ Thus, Kaplow and Shavell argue that there is always a Pareto-improving tax-and-transfer alternative to any income-redistributive legal rule. The implication of this argument is compelling: As a matter of theory, any amount of income redistribution-even a single dollar-always will be accomplished more efficiently through the tax system than through the legal system. ${ }^{107}$

A number of scholars have sought to undermine the theoretical or empirical importance of the Kaplow and Shavell double-distortion argument. In the process, this important debate has become confused.

\footnotetext{
102 See id. at 668 .
}

103 Id. at 667-68; Kaplow \& Shavell, Legal Rules, note 10, at 823 ("[I]f legal rules disadvantage high-income individuals and help low-income individuals, that will tend to discourage work effort in the same manner and to the same extent as making the income tax system more redistributive. Whether it is the tax collector or the courts that take an additional 1 percent of rich people's income and give it to the poor, the reward for work by the rich is reduced by 1 percent, so the distortion of work effort will be the same.").

104 Sanchirico, Efficiency Rationale, note 8, at 1008.

105 Id. at 1008.

106 Kaplow \& Shavell, Legal System, note 5, at 674 ("The conclusion is that adopting the efficient legal rule, with an appropriate change in the income tax, leaves all individuals equally well off but leaves the government with a surplus. With this additional revenue, the government can make each individual better off-for example, by lowering taxes ... by a fixed amount for each individual or spending the funds on a public good that benefits everyone.").

107 As Kaplow and Shavell put it, "even though the income tax distorts work incentives, any regime with an inefficient legal rule can be replaced by a regime with an efficient legal rule and a modified income tax system designed so that every person is made better off." Id. at 669 (italics removed from entire sentence). This theoretical point explicitly assumes away differential administrative costs. Kaplow and Shavell, however, contend also that redistributive legal rules are probably more costly to administer than the alternative. Id. at 675 n.12. 
In the following Section, we summarize these responses, explain where we agree and disagree, and generally try to clear up the confusion.

\section{b. Objections to the Pareto-Superiority Argument}

Two general categories of objections can be raised against Kaplow and Shavell's argument. First, objections can be raised from within the traditional law and economics framework. That is, even if we grant the standard assumptions that individuals are rational and unbiased in their decisionmaking, it can be argued at least that the Paretosuperiority argument is overstated and perhaps that it is, in some important ways, wrong. ${ }^{108}$ A second type of response to Kaplow and Shavell's argument comes from outside of the traditional neoclassical framework. Specifically, relying on observations from behavioral economics and cognitive psychology, some scholars have identified circumstances in which income redistribution might be done more efficiently through the legal system. ${ }^{109}$

108 One critique of the double-distortion part of the Pareto-superiority argument raised by Sanchirico can be called the fallacy of distortion counting. The argument is that redistributive adjustments to otherwise efficient legal rules will not necessarily produce an overall loss of social welfare (as compared with a world in which legal rules are set only to achieve efficiency and the tax-and-transfer system is the sole means of redistribution), because those adjustments may offset some other distortion in the economy. Indeed, Sanchirico explicitly invokes the "theory of the second best," by noting that "eliminating some distortions is not necessarily welfare-improving in a world in which other distortions remain." Sanchirico, Efficiency Rationale, note 8, at 1017 (emphasis omitted). Thus, the implication is that Kaplow and Shavell are wrong to regard two distortions as being worse than one. As Kaplow and Shavell note in their response, however, there seems to be no reason to expect that these two distortions-the regulated-activity distortion and the workleisure distortion - will offset each other. Kaplow \& Shavell, Legal Rules, note 10, at 824 n.5, 825-27. Sanchirico suggests that the two might be offsetting if, for instance, the regulated-activity distortion amounts to a tax on leisure, which would tend to reduce the workleisure distortion. Sanchirico, Efficiency Rationale, note 8, at 1018. If that were so, it would reduce the distortionary effects of (and might therefore be a useful complement to) an income tax. Kaplow and Shavell's response to this argument is to point out that, first, taxing leisure to reduce the work distortion associated with an income tax is entirely consistent with their framework and that, second, the better approach would be to use the tax system rather than the legal system to impose a tax on leisure. Kaplow \& Shavell, Legal Rules, note 10, at 824 n.5. Indeed, a tax on leisure activities (or on goods that tend to be used in leisure activities) has long been recognized as an efficient, counter-distortionary source of tax revenue, in comparison with the income tax.

109 Another type of criticism of the double-distortion argument denounces the naive political theory implied by such a regime. See, e.g., Scott Shapiro \& Edward F. Mcclennen, Law-and-Economics from a Philosophical Perspective, in 2 The New Palgrave Dictionary of Economics and the Law 460, 463 (Peter Newman ed., 1998) [hereinafter New Palgrave Dictionary]. We address that argument briefly in the conclusion. See text accompanying notes 281-83. 


\section{i. The Internal Critique}

Our internal critique of the Pareto superiority argument involves three steps. ${ }^{110}$ First, we argue that income-redistributive legal rules probably would not produce a double-distortion in precisely the way that Kaplow and Shavell suggest in their paradigmatic example of a "tort tax." Second, following Sanchirico, we note that Kaplow and Shavell's model depends importantly on the unrealistic assumption of homogenous taxpayers. Third, we argue that, under the more realistic assumption of heterogeneous taxpayers, designing a Pareto-superior tax-and-transfer alternative to a tort tax would be administratively impossible. We summarize these three points briefly here. ${ }^{111}$

In their tort-tax example, Kaplow and Shavell argue that "using legal rules to redistribute income distorts work incentives fully as much as the income tax system-because the distortion is caused by the redistribution itself-and also creates inefficiencies in the activities regulated by the legal rules."112 For example, if a rule were introduced making wealthy tort defendants pay an extra "tort tax," not only would wealthy potential tortfeasors take excessive levels of care (owing to the rule's inefficiency), they also would reduce their work effort by precisely the same amount as they would under a direct income tax where the legal rule was set to achieve efficiency only. We disagree. Under an income-redistributive tort rule, wealthy potential tortfeasors could reduce their overall income tax (as well as their overall tort liability) either by changing their work effort or by changing their engagement in the regulated activity or both. (Thus, in a sense, the income-redistributive tort rule gives wealthy potential tortfeasors two degrees of freedom, whereas the income-independent regime gives them only one.) And it is an empirical question whether, with the introduction of an income-redistributive tort regime, there would be more, less, or the same amount of care-level investments. ${ }^{113}$

Kaplow and Shavell presumably would respond that, even if the preceding argument were true (even if the introduction of a tort tax would not necessarily result in rich potential tortfeasors taking excessive care), whatever combination of changes in work activity and care-

110 In our version of the internal critique, we draw heavily on a similar critique offered by Chris Sanchirico. Sanchirico, Efficiency Rationale, note 8; Sanchirico, Taxes, note 10.

111 For a fuller development of this argument, see generally Ronen Avraham, David Fortus \& Kyle D. Logue, Revisiting the Role of Legal Rules and Tax Rules in Income Redistribution (Univ. of Mich. Law \& Economics Working Paper \#02-004), available at http://papers.ssrn.com/sol3/papers.cfm?abstract_id=31300 (May 31, 2002).

112 Kaplow \& Shavell, Legal System, note 5, at 667-68.

113 It is worth emphasizing that nothing in Kaplow and Shavell's analysis contradicts our conclusion in the main text. It is just their paradigmatic example (which we suspect many people conceive as the intuition behind the theory) that we find misleading. 
level investments occurred, it would be possible to construct a taxand-transfer regime (along with an efficient, income-independent tort rule) that would leave everyone better off and would produce more tax revenue.

As Sanchirico points out in his critique of the double-distortion argument, the way that Kaplow and Shavell construct such a regime is to assume that all individuals are identical in every way (they are homogeneous) except for differences in income. ${ }^{114}$ This assumption is not merely for simplicity; it is an assumption that drives the results. ${ }^{115}$ If we allow for the possibility that individuals are heterogeneous at given levels of income, however, Kaplow and Shavell's model does not work. That is, under their model, it becomes impossible to construct a general Pareto efficient tax-and-transfer regime, by which we mean a Pareto efficient regime that applies the same tax function to all people at the same level of income.

Working under the more realistic assumption of heterogeneous individuals, it nevertheless may be possible in theory to construct a taxand-transfer regime that has a tailored tax function that indeed would leave every individual exactly as well-off as she was under the incomeredistributive tort regime. The information burden that such an approach would place on the policymaker and on the taxing authority, however, would be heavy.

Consider the tort tax again. If we imagine that individuals differ from one another not only with respect to work effort and earning power but also with respect to how much they invest in accident avoidance, how much harm they have caused, and how accident prone they are (which seem like reasonable assumptions), the policy planner who wanted to implement a redistribute tax-and-transfer regime that was Pareto superior to the redistributive-legal rule alternative would need to have a great deal of information-information that the tax authorities are not in the best position to gather, such as the individual's cost of care, harm suffered, or net expected damage payments. ${ }^{116}$ Moreover, using a legal rule to do the same amount of redistribution potentially would be feasible. ${ }^{117}$ Given these informational demands,

114 Sanchirico, Efficiency Rationale, note 8, at 1056-69.

115 Id.

116 In Kaplow and Shavell's model of a tax-and-transfer alternative to an income-redistributive legal rule, they seem to say that the tax authority-that is, whoever is "constructing" the tax regime-would need such information. Kaplow \& Shavell, Legal System, note 5 , at 678 ("Note that ... the new income tax ... is constructed by beginning with the initial income tax ..., adding total accident costs under the initial, inefficient regime and subtracting total accident costs under the efficient regime. The former total (under the inefficient rule) is the first term in large brackets: the cost of care, harm suffered, and expected damage payments, minus expected damage awards received.").

117 See Avraham, Fortus \& Logue, note 111. 
the claim that there always will be a tax-and-transfer alternative to the income-redistributive tort rule that will be Pareto efficient seems, at the least, overstated.

Our internal critique of the Pareto-superiority argument, of course, does not demonstrate that the legal system is a better income redistributor than the tax system is. Rather, it merely calls into question the Pareto argument as an independent justification for always preferring the tax-and-transfer system as the best policy instrument for redistributing income. We ultimately conclude that the tax-and-transfer system probably is better than the legal system overall as a means of systematically reducing income inequality, but we base our conclusion on the fact that the tax system clearly seems to be the better proxy observer when it comes to income and, as redistributor, the tax system seems less susceptible to the contracting-around and haphazardness problems. These conclusions assume that individuals are rational and unbiased in their decisionmaking. As the following Section demonstrates, if that assumption is relaxed, the case for the exclusive use of the tax system for income redistribution is weaker.

\section{ii. The Behavioralist Critique}

As just mentioned, one of the key assumptions of the double-distortion argument is that individual taxpayers in their work-leisure decisions would respond to an income tax implemented indirectly through the tort system in the same way that they would to an income tax that is implemented directly through the tax system. ${ }^{118}$ Thus, the work disincentive would be the same under either regime. The behavioral economics critique calls that assumption into question in a very different way than the neo-classical economic tradition: by pointing out two well-known quirks in human cognition that suggest that the work-leisure distortion caused by a income-redistributive legal rule might be smaller than the work-leisure distortion caused by a direct income tax (accompanied by an efficient legal rule). ${ }^{119}$

The most complete statement of the behavioralist critique appears in an article by Christine Jolls. ${ }^{120}$ Jolls first observes that redistribution through a legal rule, such as an income-adjusted tort rule, has a probabilistic element (or element of uncertainty) that is not present

118 See text accompanying note 112 .

119 As becomes clear as the argument progresses, the behavioralist critique is inconsistent with our two-degrees-of-freedom argument in the previous Section. See text accompanying notes 111-17.

120 Jolls, Behavioral Economics, note 36. Jolls explicitly restricts her analysis to tort rules that operate between strangers. Id. at 1657. Mark Kelman has made some of the same points made by Jolls. Kelman, note 39 . 
when redistribution is accomplished through a direct tax.121 The probabilistic element has to do with whether the tort tax will apply at all. Observe that under a direct income tax an individual who earns income above a given amount during a particular taxable period can be sure of incurring a given, determinate tax liability. ${ }^{122}$ Under the income-adjusted tort rule, however, even if the individual knows the amount of income she will have in a particular year as well as the amount of tax on that income, she does not know whether the tax will apply to her, because there will be no tax liability unless the individual is involved in an accident for which she is held liable. ${ }^{123}$

Although the probabilistic character of redistributive legal rules has been a source of criticism from traditional legal economists (the haphazardness argument is in a sense a critique of the probabilistic aspect of a redistributive legal rule), it is quite useful from the cognitive perspective. The basis of the argument is this: When faced with conditions of uncertainty, people often make decisions that are not predicted by the standard rational-actor models of traditional economics. Instead, as cognitive psychologists have documented for decades, people in such situations often exhibit various cognitive heuristics and biases, which behavioral economists argue should be taken into account in the economic analysis of law. Jolls makes use of two such cognitive quirks to argue that the economic analysis of redistributive legal rules is more complicated than the conventional view (associated with Kaplow and Shavell) would suggest.

The first cognitive bias that Jolls explores is the well-documented finding that individuals facing a very small likelihood of a loss tend to behave optimistically; that is, they tend to underestimate the likelihood that low-probability bad things will happen to them, especially bad things over which they have some control. ${ }^{124}$ Jolls' argument rests on the claim that the same tendency may apply to probabilistic taxes

121 Jolls, Behavioral Economics, note 36, at 1658-63.

122 Id. at 1656. There is of course some uncertainty inherent in the enforcement of the income tax, and as Sanchirico argues, there may be uncertainty regarding how much income a person is likely to earn in a given taxable year. But those same uncertainties would be present under a redistributive rule as well. Sanchirico, Efficiency Rationale, note 8 , at 1053. What is significant is that, with a redistributive legal rule, there is an additional uncertainty that is not present with an income tax regime: the uncertainty as to whether an event will occur giving rise to a redistributive transfer through legal rules.

123 Jolls, Behavioral Economics, note 36, at 1658-63.

124 . Id. Thus, "most people think that their probability of a bad outcome is far less than others' probability [of the same sort of bad outcome], although of course this cannot be true for more than half the population." Jolls, Sunstein \& Thaler, note 79, at 1524; see also Neil D. Weinstein, Unrealistic Optimism About Future Life Events, 39 J. Personality \& Soc. Psych. 806, 818 (1980); Neil D. Weinstein, Unrealistic Optimism About Susceptibility to Health Problems: Conclusions From a Community-Wide Sample, 10 J. Behav. Med. 481, 494-96 (1987). 
implemented indirectly through legal rules. ${ }^{125}$ If we assume, for example, that an individual's likelihood of being subject to a tort tax in any given year is small (because her likelihood of being in an accident that causes damages for which she is held liable is small), we should expect that the individual would behave as if such a tax had a lower probability of occurring than is objectively so. By contrast, taxes imposed directly through the tax system are less probabilistic than the tort tax and hence would produce less of an optimism-bias effect. If one grants all of these assumptions, assumptions that Jolls herself admits must be verified empirically, the conclusion is intriguing: An income-adjusted tort rule would be less distortive of work incentives than a direct income tax. ${ }^{126}$

Consider Jolls' example illustrating this point. ${ }^{127}$ Assume that the policymaker wants to impose an additional $\$ 10,000$ annual tax on each "high-income" individual.128 There are two approaches to achieving that result: the direct income tax and the income-adjusted tort rule. Under the former, the policymaker imposes a new tax of $\$ 10,000$ directly on the high-income individuals and only on high-income individuals. Under the equivalent tort-tax approach, the policymaker determines that, given that the actual likelihood of a high-income person having to make a payout in a tort case is $2 \%$, the amount of the income adjustment to the tort damages would need to be $\$ 500,000$.

\begin{abstract}
The great majority of individuals believe themselves to be better than average drivers, more likely than average to live past 80 , less likely than average to be harmed by products they use. [This is because] ... the risk looks very small from the perspective of each individual's experience. Consider automobile driving: [d]espite driving too fast, tailgating, etc., poor drivers typically go trip after trip without mishap. This personal experience demonstrates to them their exceptional skill and safety. Moreover, their indirect experience via the news media shows them that when accidents happen, they happen to others. Given such misleading experience, individuals may feel quite justified in refusing to take protective actions such as wearing seat belts.
\end{abstract}

Paul Slovic, Baruch Fischhof \& Sarah Lichtenstein, Facts Versus Fears: Understanding Perceived Risk, in Judgment Under Uncertainty: Heuristics and Biases 470 (Daniel Kahneman, Paul Slovic \& Amos Tversky eds., 1982).

125 Jolls, Behavioral Economics, note 36, at 1662 ("People will tend to underestimate the probability that they will be hit with liability under a redistributive legal rules; therefore, their perceived cost of the rule will be lower. As a result, their work incentives will tend to suffer a lesser degree of distortion than under a tax yielding the same amount of revenue for the government."). Note, however, "that the role of overoptimism is likely to vary significantly with the context. In a case in which the threat of being found liable is highly salient, individuals may tend to overestimate the likelihood of being sanctioned." Jolls, Sunstein \& Thaler, note 79, at 1525 (emphasis omitted).

126 Jolls, Behavioral Economics, note 36, at 1663.

127 Id. at $1655-56$.

128 Jolls has in mind the use of a class-based redistributive rule, though she does not use that specific terminology. Id. at 1670 . Below we suggest some problems with the use of a class-based rule to create a probabilistic income tax. See text accompanying notes 135-36. 
Hence, the expected value of this tort tax for a particular year is $\$ 10,000$, which is equivalent in expected value terms to the annual direct tax.

But here is the trick: If the high-income individual perceives the likelihood of the tort rule applying to her-the likelihood of being in an accident and then being found legally responsible-to be, say, $1 \%$ instead of $2 \%$, the perceived expected value of the tort tax would be only $\$ 5,000$. The perceived expected cost of the direct income tax, however, would be $\$ 10,000$ because there is no optimism bias. The implication of this observation for the work incentives of the highincome individual is that, by raising the additional $\$ 10,000$ from the high-income individual through a tort tax rather than a direct income tax, the work distortion is cut in half. Put more generally, if individuals underestimate the likelihood of low-probability, uncertain bad things happening to them (such as tort suits), then a redistributive legal rule may produce a smaller work disincentive than a similarly redistributive income tax would. ${ }^{129}$

This observation is potentially important for the debate over the appropriate use of income-redistributive legal rules. In fact, we think the implications of the optimism bias may be more significant than even Jolls suggests (again, ignoring liability insurance for now). If this bias does apply to redistributive legal rules such as income-adjusted tort rules, then not only would the work distortion be reduced, but the second distortion (the regulated-activity distortion) would be reduced as well. That is, if the tax that distorts the regulated-activity decisions (how much or how carefully to engage in the regulated activity) were underestimated systematically, the distortionary effect of that tax on regulated activity also would be less. This would be true even if, in response to the optimism bias, the legal rule were adjusted upward to achieve optimal regulated-activity conduct. ${ }^{130}$

Indeed, if the optimism bias were to apply to individuals' perceptions of the likelihood of being affected by legal rules generally (and, as Jolls assumes, not to the likelihood of being affected by the tax system), ${ }^{131}$ and if this optimism bias were sufficiently large, such a conclusion would provide an argument for favoring income-redistributive legal rules over the income tax-and-transfer system. ${ }^{132}$ To emphasize this theoretical point, imagine that individuals actually behaved as

\footnotetext{
129 Jolls, Behavioral Economics, note 36, at 1663.

130 As Jolls notes, "[i]f potential tortfeasors underestimate the probability of liability, the efficient (meaning optimal-deterrence-achieving) legal rule would be more generous to tort victims than the efficient legal rule without underestimation of probabilities would be." Id. at 1662 n.38.

131 Id. at 1656.

132 See id. at 1663 .
} 
if the likelihood of their being held liable in tort were zero. In such a scenario, legal rules would provide the perfect tool for income redistribution (again, putting aside the haphazardness complaint). There would be no distortion whatsoever-no distortion of work decisions or of regulated activity. ${ }^{133}$ A redistributive legal rule would be the perfect lump sum tax. With the income tax, however, there always would be at least some work-leisure distortion. ${ }^{134}$

There is one problem, however, with Jolls' use of the optimism bias to construct a probabilistic (or lump sum) defense of an income-redistributive legal rule. Jolls leaves unspecified how the high-income status would be determined under such a rule. She does suggest that what she has in mind is what we call a class-based redistributive rule. ${ }^{135}$ There are problems with a class-based approach, however. First, if she has in mind corporations as a class of defendants, it is less clear that optimism bias would apply. ${ }^{136}$ Second, if she has in mind a class of rich individuals as the target of her probabilistic tax, it is unclear how a class-based redistributive rule would be designed to target such a group. Of course, a case-specific approach, as we describe above, would allow such targeting of high-income individuals. ${ }^{137}$

In addition to the optimism bias, Jolls considers the implications of the psychological phenomenon known as "mental accounting." As Jolls puts the point, "[ $\mathrm{t}]$ he idea behind 'mental accounting' is that people do not always view a dollar spent in the same way; it may matter from which 'account' the dollar is coming. Money is not fungible in the way that standard economics assumes."138 What this idea says about income-redistributive legal rules, is this: Income-redistributive dollars paid through the tax system are perceived as a tax on income, whereas income-redistributive dollars paid through the tort system (the proverbial tort tax) are perceived simply as extra tort damages. Or, as Jolls notes, the tort tax may be viewed as "expenditures out of income (rather than direct charges against income);" and the former may cause less of a work distortion than the latter. ${ }^{39}$ Thus, according

133 Note, however, that the larger the optimism bias, the lower the deterrent effect of tort law. Under the assumptions just stated, tort law would have no deterrent effect.

${ }^{134}$ Let us be clear on this. We do not mean to suggest repealing the income tax and doing all income redistribution through the legal system. We use this extreme example only to make the point that the optimism bias, to the extent it would apply differentially (more to redistributive rules than to redistributive taxes), is a potentially very important phenomenon for redistributive policy.

135 Id. at 1620 .

136 For an analysis of cognitive biases in firms, see generally Donald Langevoort, The Human Nature of Corporate Boards: Law, Norms, and the Unintended Consequences of Independence and Accountability, 89 Geo. L.J. 797 (2001).

137 See text accompanying note 128.

138 Jolls, Behavioral Economics, note 36, at 1669.

139 Id. at 1670 . This phenomenon has been demonstrated in a number of con' 'xts. 
to the mental accounting story, whereas income redistribution accomplished through the tax system produces a relatively large work distortion and no regulated-activity distortion, income redistribution through the legal system would produce a relatively small work distortion as well as a regulated-activity distortion. Hence, the relevant empirical question for the policymaker would be to determine whether the reduced work distortion under a redistributive legal rule would more than offset the regulated-activity distortion. ${ }^{140}$

To summarize, the behavioralist critique raises some questions about the real-world significance of the double-distortion argument. ${ }^{141}$ Because of the effect of the optimism bias (on both the work distortion and the regulated-activity distortion) and the mental accounting effect (on the work distortion), income redistribution through the legal system may be no less distortive overall than income redistribution through a tax-and-transfer system. We agree with that conclusion. We also agree, however, with Jolls' qualification of her conclusion, which says that there must be additional empirical work to determine the ultimate significance of these theoretical observations. ${ }^{142}$ It is well known that behavioral findings are not always qualitatively robust and are often not quantitatively robust. ${ }^{143}$ Thus, what is needed is additional research on the extent to which the optimism bias applies to

140 It is interesting to note that Jolls' mental accounting argument expressly depends on the assumption that the redistributive legal rule in question will be a class-based redistributive rule, one that is designed to redistribute from a class of potential defendants (or plaintiffs) to a class of potential plaintiffs (or defendants) based on a determination that the average income of the former class is greater than the average income of the latter. Jolls, Behavioral Economics, note 36, at 1670 . With a class-based redistributive rule, there is a disconnection between an individual's income and her tax liability that would not exist with a direct tax on income. This distance between cause and effect may explain why people would place indirect taxes into a different mental account and thus, in making their work decisions, simply ignore them. Jolls also notes, however, that if legal rules are "explicitly conditioned" on the income of the parties (what we call a case-specific redistributive rule), this disconnection would disappear or diminish, and the mental accounting point would be inapplicable or less powerful. Id. at 1670 . Jolls observes that "such rules have commanded little support among commentators." Id. This is true in one sense, but not in another. See note 61 (discussing assumptions made by Kaplow and Shavell and Sanchirico concerning use of class-based rules).

141 Note that Kaplow and Shavell acknowledge the potential significance of cognitive biases, but do not explore the issue. Kaplow \& Shavell, Legal System, note 5, at 671 n.5.

142 Jolls, Behavioral Economics, note 36, at 1672-73.

143 For example, Jennifer Arlen, Matthew Spitzer, and Eric Talley found that the endowment effect does not exist in some contexts involving agency relationships. Jennifer Arlen, Matthew L. Spitzer \& Eric L. Talley, Endowment Effects Within Corporate Agency Relationships, available at http://papers.ssrn.com/sol3/papers.cfm?abstract_id=276110 (July 16, 2001). Moreover, even the endowment effect, which is usually thought to be robust, appears in different magnitudes in different contexts. For example, it is larger when public goods are involved. See, e.g., John K. Horowitz and Kenneth E. McConnell, A Review of WTA/WTP Studies, available at http://papers.ssrn.com/sol3/papers.cfm?abstract_id= 257336 (Feb. 11, 2001). 
perceptions of the likelihood that legal rules will apply to them. In addition, however, there needs to be further research into how the presence of insurance would affect the analysis.

The preceding analysis ignored the effects of insurance. As it turns out, introducing insurance in the story would facilitate the redistributive capacity of legal rules but would also exacerbate the regulatedactivity and work-leisure distortions. To see this point, imagine that everyone has complete and perfectly risk-adjusted liability insurance as well as first-party insurance (life, health, disability, and property). As is well known among tort and insurance scholars, if liability insurance premiums adjusted perfectly to reflect each insured's individual expected costs at all times, those premiums would facilitate the deterrence effect of tort law, by causing insureds to fully internalize all of the external costs associated with their actions. Insured potential injurers would be induced to take efficient care in avoiding accidents, because failing to do so would cost them more in increased insurance premiums than would investing in accident avoidance. Likewise, perfectly-adjusting, first-party premiums prevent moral hazard on the victim side as well, inducing individuals to take cost-effective measures to reduce their own expected costs.

Although perfectly-adjusting insurance premiums are efficiency-enhancing with respect to the deterrence portion of the legal rule, they would be efficiency-reducing with respect to the redistributive portion of that rule. That is, to the extent premium increases represent purely an increase in insured's expected implicit tort-tax liability, those premium adjustments would produce both the regulated-activity distortion and the work-leisure distortion that Kaplow and Shavell have in mind. Thus, reconsider Jolls' example discussed above, in which there was a $\$ 500,000$ tax imposed on rich tort defendants who are held liable, whereas no tort tax is imposed on the nonrich. ${ }^{144}$ If we introduce perfectly risk-adjusted liability insurance for this potential redistributive damage award, the premium (again assuming a $2 \%$ probability of loss) for coverage for the risk of being forced to pay that tort tax would be set at $\$ 10,000$. Again, that would be the insurance premium to cover only the redistributive tort tax.

A corollary assumption is that, if the probability of the liability rule's applying were to change over time (say, it went from $2 \%$ to $2.5 \%$ ), the insurance premium would change instantly to reflect that fact; likewise, if the individual's income changed (hence causing a change in the ex post tort tax from $\$ 500,000$ to something else), the insurance premiums would change accordingly. Because we are assuming perfectly risk-adjusting premiums, the accuracy of the redis-

144 See text accompanying notes 127-28. 
tributive transfer also would be perfect, in the following sense: The rich and only the rich would pay the higher premium/tax; everyone else would pay the lower amount, which does not contain the tort tax. In effect, the insurance companies would serve as a sort of private IRS (in fact, insurance companies would compete to serve as the private IRS), and they would have the responsibility of identifying the high income and the low income, separating them into separate pools, and collecting the higher premiums (that is, taxes) from the former and the lower premiums from the latter. By assumption, the accuracy of the redistribution would be close to perfect.

At the same time, and for the same reasons, with perfectly risk- and income-adjusted premiums, both the regulated-activity and work-leisure distortions would be present even under the assumptions of the behavioralist critique. Under the behavioralist argument, the individuals in our example would perceive the expected tort tax to be only $\$ 5,000(.01 \times \$ 500,000)$ rather than $\$ 10,000(.02 \times \$ 500,000)$, which is the unbiased assessment. But that bias was attributed to the probabilistic nature of the tort tax. When the tax is made certain through the insurance premium (which is, in fact, the whole purpose of insurance), the optimism bias presumably would disappear, removing one of the behavioralist justifications for preferring redistributive legal rule to redistributive taxes. ${ }^{145}$

The next question is whether the mental accounting effect likewise would also disappear. Maybe, maybe not. The answer probably depends on how insurance companies design their premium statements. If, under the income-adjusted tort regime, insurers included a separate line for the income tax portion of the premium, that practice certainly would make dollars paid for the tort tax look a lot more like the dollars paid for the direct income tax. ${ }^{146}$

145 Jolls acknowledges that the presence of insurance may undermine the optimism-bias argument in favor of redistributive legal rules. Jolls, Behavioral Economics, note 36, at 1665. She notes, however, that "[b]ecause insurance almost always involves some combination of deductibles, copayments, and experience rating (to mitigate problems of moral hazard), even with insurance there will be some uncertainty about the degree to which a redistributive legal rule will affect a given individual. . ." Id. at 1663 (emphasis omitted). Deductibles, copayments, and experience rating are rough substitutes for perfectly riskadjusted premiums. Thus, Jolls is saying that to the extent that insurance is not perfectly risk-adjusted, there will remain some uncertainty and hence some room for the optimism bias to work. This conclusion, however, significantly weakens Jolls' main point about the use of income-redistributive legal rules as probabilistic taxes.

146 Jolls acknowledges this point in her discussion of the mental accounting effect: "Of course, the degree to which a redistributive legal rule or tax is viewed as a direct charge against income, and hence a direct disincentive to work, may be influenced by the way in which it is presented. If $\mathrm{W}-2$ forms listed expected tort obligations under a redistributive legal rule, then the costs of the rule might be more likely to be charged directly against income. This would make redistributive legal rules more like taxes." Id. at 1671. 
Although we would not expect insurance premiums to be perfectly or even nearly perfectly adjusted to reflect individual insureds' differing risk characteristics (which are relatively difficult to observe), we assume that insurers would do a reasonably good job of adjusting their premiums to reflect differences in insureds' income levels. First, market competition would encourage insurers to income-adjust their premiums (just as it encourages them to risk-adjust their premiums), in order to keep the middle- and low-income customers from self-insuring. Second, insurers would be able to determine an individual's income level, at least his annual income, at a relatively low cost. They simply could insist on seeing the individual's W-2 form or several months of pay stubs. In fact, it seems likely that income-adjusted insurance premiums would be less costly administratively than risk-adjusted premiums. If we are right about this, then we can conclude that the presence of insurance generally would increase the accuracy and the breadth of the income-redistributive legal rule, but also would increase the distortions caused by the redistributive element of the rules. ${ }^{147}$

\section{Examining the Case for Always (Though Not Exclusively) Using Legal Rules to Redistribute Income}

In a pair of recent articles, Sanchirico, in addition to attacking Kaplow and Shavell's case for never using legal rules to redistribute income, offers a series of arguments in support of the conclusion that legal rules should be used to redistribute income. ${ }^{148}$ In one respect,

147 If insurers are not able to discriminate among insureds on the basis of income (or if, for some reason, they were forbidden by law from doing so), then the use of incomeredistributive legal rules could lead to wildly regressive results. Consider the extreme case in which, despite the differential income effect of the tort tax, all insureds, irrespective of income, are required by law to be charged the same premium for liability insurance. In effect, everyone's premium would equal the average expected loss of the pool plus the average tax liability, and everyone would pay the same premium. The effect of these assumptions would be to produce a regressive tort tax. That is, income would be shifted to the rich from the nonrich. In our example, the rich should pay a tort tax in their insurance premiums of $\$ 10,000$ (because, if they were held liable, which is a $2 \%$ probability, the insurance company would have to pay out an extra $\$ 500,000$ in damages) and the nonrich should pay no such additional premium. With nonadjusting liability insurance, however, both the rich and the nonrich would pay a $\$ 5,000$ tort tax adjustment (assuming equal numbers of rich and nonrich in the insurance pool). Thus, not only would the rich be shifting the $\$ 500,000$ ex post tax to the insurance pool, they would be benefiting from a financing arrangement that, in effect, would impose a regressive tax structure on the members of the insurance pool.

148 In another part of his analysis, Sanchirico also points out that there are other proxies for ability besides income-such as accident proneness-and that adjustments to legal rules on the basis of those nonincome proxies will not produce the double distortion problem. Sanchirico, Efficiency Rationale, note 8, at 1060. That, in our view, is Sanchirico's most important contribution to the debate regarding redistributive legal rules, and we 
Sanchirico's position is the mirror image of Kaplow and Shavell's position: Whereas Kaplow and Shavell argue that legal rules should never be income-redistributive, Sanchirico seems to argue that his analysis, taken to its logical conclusion, would lead to the result that legal rules always should be income-redistributive (if income is determined to be the dominant measure of well-being), although he qualifies this conclusion. ${ }^{149}$

We conclude that both claims are overstated. Instead, our view is that whether legal rules should ever be income-redistributive (that is, whether legal rules should ever be used to reduce income inequality) depends entirely on whether there are circumstances in which the legal system has a comparative advantage either at observing income or redistributing with respect to income. And the comparative advantage issue, in our view, ends up turning almost entirely on the contracting-around and haphazardness arguments. In this Section, we explain why we are unpersuaded by Sanchirico's arguments in favor of income-redistributive legal rules.

The first of Sanchirico's arguments is what he calls the "optimal-tax argument for equity informed legal rules."150 At its core, the optimaltax argument rejects Kaplow and Shavell's premise that all redistributive adjustments to efficient legal rules necessarily produce a regulated-activity distortion. Recall Kaplow and Shavell's argument that, as soon as a legal rule departs from the efficient design, it produces inefficiency with respect to the conduct regulated by the rule. To take the torts example, if we alter the liability rule or the damages calculation to make the law redistributive even slightly (if, for purely redistributive reasons, we move even slightly in the direction of strict liability when negligence is the efficient rule, or we raise damages even one dollar above the efficient level), there will be a distortion with respect to investments in accident avoidance. In this example, too much care will be taken to avoid a particular type of accident. It is this regulated-conduct distortion that, in Kaplow and Shavell's view, always will tip the scale in favor of using the tax system to reduce income inequality, since the work-leisure distortion always will be pre-

build on that insight in the next Section. In this Section, however, we focus on Sanchirico's arguments in support of income-adjusted legal rules.

149 See, e.g., id. at 1019 ("No claim is being made that the optimal-tax analysis provided in this Part proves definitively that policymakers should always set legal rules with equity in mind. The purely economic arguments in this Part do not address all relevant considerations. What is claimed-definitively-is this: The kind of analysis provided here, which forms the most prominent argument for pure efficiency in law, not only fails to support the claim that legal rules should never be redistributive, but leads to the more than opposite conclusion that redistributive goals should always inform legal rules.") (footnote omitted). $\mathrm{He}$ also qualifies this assertion at a later point in the article. Id. at 1026 n.56.

150 Id. at 1018. 
sent in precisely the same degree with respect to any sort of income redistribution. ${ }^{151}$

Sanchirico's response to this observation is clever, if somewhat complex. Relying on basic assumptions commonly made by microeconomic theorists, he argues that any initial adjustments away from an efficient legal rule in fact will not produce inefficiency. ${ }^{152}$ The reason has to do with the assumption that the social welfare function that is being maximized is smoothly sloping, that is, it has no kinks or jumps but is instead "continuous." Under this assumption, at the point at which a rule is set to "maximize" efficiency, any small departures from that efficient rule in either direction will not cause a loss of utility, because the curve is by definition flat (that is, with a slope of zero) at the point of maximization. ${ }^{153}$

Although Sanchirico cannot specify how large this flat range of the curve will be, and thus how far the legal rule can depart from the efficient rule before distortion would set in, he admits that range may be small, perhaps "infinitesimal." 154 The conclusion Sanchirico derives from this is that, if the redistribution-minded policymaker were to limit herself to only a single redistributive policy instrument, she essentially would be wasting resources. Loading all of the redistributive work onto one redistributive system increases the likelihood that the flat range on the social welfare curve will be exceeded, at which point distortions (of the regulated-conduct variety) would occur. Instead, the policymaker should spread the redistributive work among all the available redistributive tools so as to get the full benefit of the perhaps small (but nonzero) distortion-free redistributive capacity available in each redistributive tool. As Sanchirico puts the point, policymakers should spread the redistributive work around "because every tool is initially perfectly redistributional, and no tool remains perfect once employed." 155

This argument is valid, as far as it goes. But its empirical significance is doubtful. Again, the key assumption in the argument is that of a smoothly continuous social utility function, an assumption that Sanchirico admits his analysis depends on and that he admits has no basis in empirical fact. The assumption may be convenient for modeling purposes, and it may even be an accurate picture of the world in some contexts, but it seems a thin reed on which to hang such an im-

151 But see text accompanying notes 108-47 (criticizing this latter assumption).

152 Sanchirico, Efficiency Rationale, note 10, at 1023-24 ("Thus, on the margin, movements away from the efficient legal rule have no impact on total utility, but-if we move in the right direction-a beneficial impact on inequality.").

153 Id. at 1022.

154 Id. at 1024.

155 Id. at 1022. 
portant argument. ${ }^{156}$ Moreover, even if the assumption of a kinkless utility function does hold, the range of distortion-free redistributive adjustments - the flat portion of the curve-may be, as Sanchirico admits, "infinitesimal." 157 If that were so, then Sanchirico's point here most likely would be small as well.158

In what appears to be a second, separate defense of income-redistributive legal rules, Sanchirico builds on the idea that the ultimate target of a welfarist redistributive policy should be individual well-being, ${ }^{159}$ but that well-being is itself unobservable. Because well-being is unobservable, the redistribution-minded policymaker must focus on proxies or outward manifestations of the inner state of well-being. ${ }^{160}$ Income is one such proxy (and indisputably an important one) but not the only one. On Sanchirico's list of other proxies are the familiar ones of wealth and consumption. ${ }^{161}$ In addition, however, he adds the proxy of "damages caused in accidents" 162 as a proxy for "accidentproneness." And the more of these proxies the policymaker takes into account, the more accurate the redistribution will be with respect to the true underlying target-differences in well-being. ${ }^{163}$

All of this makes sense if one is working within a traditional welfarist framework. ${ }^{164}$ From this insight, however, Sanchirico seems to conclude that both the legal system and the tax system should be designed to take into account every possible proxy for well-being. ${ }^{165}$

156 See id. at 1023, n.51, 1026 n.56.

157 Id. at 1023.

158 More precisely, for his argument to have any real-world significance, the point of maximization would have to be (coincidentally) at a point where even a minute amount of redistribution was valued extraordinarily highly by society. The likelihood of such a coincidence seems remote.

159 Id. at 1022.

160 Id. at 1020.

161 Id. at 1027.

162 Id. at 1027. Sanchirico also mentions contractual activity, property owned; harm caused, and the like. Id. at 1009.

163 Id. at 1009.

164 Recall that we generally have not adopted the welfarist framework for this Article, nor any other specific political theory. Rather, we adopted an independence assumption, which suggests that a redistribution-minded policymaker will make independent redistributive decisions with respect to different types of inequality. See note 31 . We do not think that our conclusions hinge on this assumption. See discussion at text accompanying notes 259-72.

165 Sanchirico, Efficiency Rationale, note 8, at 1021-26. In fact, Sanchirico characterizes the ideal redistributive policy instrument to be a sort of "multidimensional tax table" under which each "individual's tax on each attribute [would be] a function of the levels of the individual's other attributes. Taxes can thus be cross-dependent. Income tax rates, for instance, can be based on wealth, just as damages might depend on the individual's income or wealth." Id. at 1028. As Sanchirico goes on to point out, we do in fact make adjustments to the existing income tax in order to take account of differences in consumption decisions that matter to us on distributional grounds. Id. at 1030. 
We do not see how this follows. ${ }^{166}$ Moreover, even this conclusion does not explain why legal rules in particular should be used as a redistributive policy instrument. Rather, it provides only a justification for taking into account as many proxies for well-being as possible, whatever redistributive instruments happen to be used. That is to say, the cross-dependency goal could be achieved entirely through the taxand-transfer regime, such as through a multidimensional tax table. There is nothing in this analysis that identifies legal rules as being particularly well-suited for such a function.

What seems to be Sanchirico's strongest argument for redistributing through legal rules is a sort of diminishing returns-to-scale story. $\mathrm{He}$ seems to be arguing that, even if the tax-and-transfer system is generally the preferred redistributor with respect to income, at some point (after some amount of income redistribution already has been accomplished through the tax-and-transfer system) there are diminishing returns to doing additional redistribution through that system. At that point, if policymakers wish to further increase the amount of overall income redistribution, they should not do so through the tax-andtransfer system (which is, in some sense, overloaded) but should do the additional redistribution through a different system, namely, the legal system. Thus, he seems to be arguing that the more redistribution with respect to a particular proxy is done through a given policy instrument, the less effective that instrument becomes with respect to that proxy; hence, we need to spread the income redistribution around, using the tax system a little, the legal system a little, and so on. We might call this a capacity-constraint justification for spreading the redistributive work around.

Although in theory this argument could be right, it seems unlikely. The argument assumes that there are diminishing returns to scale in redistributing income through the tax system and that, over some relevant range of income redistribution, the legal system on the margin would be more efficient than the tax-and-transfer system as a system of redistribution. These assumptions strike us as highly unlikely. Although there is no empirical evidence that we know of that would permit us to answer the question definitively, it is our intuition that, when it comes to administrative costs, there are probably increasing returns to scale, not decreasing returns to scale, in using the tax system to redistribute income. In other words, we suspect that over the

\footnotetext{
166 For example, under our approach, all of the relevant redistributive proxies would be taken into account, but the mechanism would be different. Instead of adjusting all policy instruments on the basis of every proxy for well-being, we would use the redistributive policy instrument that best suited each proxy. Overall, from an ex ante perspective, taking into account the redistributive aspect of the legal system and the tax system, the result would be the same: a focus on inequality of well-being.
} 
relevant range of redistribution, the tax-and-transfer system would exhibit increasing marginal redistributive capacity rather than decreasing capacity.

To make this point more clearly, imagine a situation in which the tax system already does some amount of income redistribution. Then the policymaker decides that a greater degree of income redistribution is desirable. In our view, it would make most sense to use the tax system for this additional redistribution as well. For reasons discussed above, the tax-and-transfer system has a comparative advantage in observing income as well as in redistributing income. We believe this advantage remains for the whole range of the relevant income redistribution space. In any event, there certainly is no obvious reason to suppose that, if the tax system becomes stretched to capacity as a system of income redistribution, the most efficient means of adding additional redistributive capacity to the overall system would be a new redistributive role to the legal system, which is not designed primarily with income redistribution in mind. It seems to us that a more efficient response would be to add more capacity to the income tax system rather than to call on the unused income-redistributive capacity of the legal system.

An important part of our framework that Sanchirico's analysis overlooks is that the various redistributive policy instruments may have different comparative advantages. In particular, even if equality of well-being is the overarching target of the redistribution-minded policymaker, such that the focus of redistributive policy is on "proxies for well-being," it is still the case that various government policy instruments are not equally well-suited to redistribution with respect to all aspects of well-being. Thus, putting our framework in welfarist terms, the policymaker should ask, with respect to each proxy for well-being, which policy instrument is the better proxy observer and which is the better redistributor with respect to that proxy.

It may be, as we argue in the next Section, that the legal system has a comparative advantage at observing certain characteristics that correlate with well-being, such as whether or not an individual is accident prone or whether or not an individual has experienced nonphysical pain and suffering. In such cases, the legal system should be used at least to observe the relevant proxy. Then the question becomes whether that information should be used in the legal system or in the tax-and-transfer system to make the tax-and-transfer system crossdependent. 


\section{Redistribution With Respect to Nonincome Inequality}

Among those who favor some sort of redistribution, there is little disagreement that large inequalities of income or wealth present an appropriate occasion for redistributive transfers. But, as discussed above, income is not the only proxy for well-being. Therefore, income inequality should not be the only target of an egalitarian or even a welfarist redistributive policy. Moreover, putting the welfarist framework to one side, a case can be made that there are other types of inequality that a redistribution-minded policymaker would (and should) care about, independent of income inequality. ${ }^{167}$

For example, even if income were distributed equally across society (or if all income differences were considered the result of pure choice, rather than a mix of choice and endowment), our intuition suggests that redistribution still would be considered appropriate for large differences in nonincome dimensions of well-being that are attributable to brute luck. ${ }^{168}$ Thus, for example, in an equal-income society, we might tax those who do not have severe disabilities in order to make cash or in kind transfers to those who do: That is, the presence of a severe disability, by itself, would be considered sufficient grounds for a redistributive transfer. The same might be said of inequality of education or healthcare. ${ }^{169}$

Under our comparative-advantage framework, if policymakers can identify nonincome measures of inequality that society cares about, they should ask the same questions that were asked above about income redistribution: Which system is the better observer of this characteristic or type of inequality? And which system is the better redistributor with respect to it? Broadening the redistributive analysis this way makes it clear that the standard categories-tax rules versus legal rules-are inadequate to capture fully the various policy options.

For example, it is unclear into which category an unfunded mandate such as the Americans With Disabilities Act would fall. The Social Security or Medicare systems also are not easily categorized. In this Section, we focus on a set of examples that, at least on first blush, seem to fall under the rubric of legal rules. Even in these cases, however, the distinctions become blurred. These are legal rules that have the following interesting qualities: They tend to promote a plausible vision of distributive justice (that is, they redistribute from those who

\footnotetext{
167 We discussed this independence assumption in the introduction, note 31 , and we return to it in the text accompanying notes 259-72.

168 See note 27.

169 Rawls, note 9, might call some of these characteristics "primary goods," and Dworkin, Law's Empire, note 9, might call them "resources." For our purposes, the terminology is not important. What is important is that there are types of inequality, independent of income, that might justify some sort of redistributive policy.
} 
are better endowed to those who are less well endowed), and they do so in a way that is arguably more efficient than a pure tax-and-transfer alternative. Our analysis, of course, does not depend on the absence of a tradeoff between efficiency and redistribution, but only is made more compelling by it. Thus, we do not reject a priori legal rules that fulfill society's redistributive goals but are inefficient.

Our claim in this Section is that, with respect to some types of inequality, the legal system should play an important redistributive role, either because the legal system is better at observing the relevant type of inequality or because the legal system is the more efficient redistributor or both. Here again, however, one of the most important observations of our analysis is that, at the margins, these categories-tax rules and legal rules-begin to break down. The question thus becomes, more generally, what institution or combination of institutions is best suited to achieve the type of redistribution that is desired.

\section{A. Redistributing Through Insurance Law}

\section{The Problem of Disease-Related Genes}

A potentially important source of nonincome-based inequality involves disease-related genes, that is, genetic characteristics that substantially increase an individual's likelihood of contracting a devastatingly costly, incapacitating, excruciatingly painful, and perhaps fatal disease. Such genetic characteristics correlate with higherthan-average lifetime health costs, shorter-than-average life spans, and presumably lower-than-average psychic income or noneconomic well-being. Moreover, at least with respect to some such diseases, an individual's genetic makeup is the sole determinant of whether the disease will be contracted. Therefore, whether or not an individual has such a disease gene is an important measure of inequality of wellbeing, the sort of inequality that likely would motivate a redistribution-minded policymaker to engage in compulsory redistribution. ${ }^{170}$

For diseases that are entirely the result of genetic inheritance and thus are unaffected by an individual's choices or by her environment (which we call "genetically-determined diseases"), the case for compulsory redistribution is especially strong. In fact, it is difficult to con-

170 As one prominent contemporary political philosopher and medical ethicist put it, even philosophers who believe that differences among individuals in terms of ability or talent do not present distributive justice concerns, "only the strictest libertarians treat health status differences merely as 'unfortunate' variations and believe that there is no social obligation to correct for the relative advantages and disadvantages caused by disease and disability." Norman Daniels, The Genome Project, Individual Differences, and Just Health Care in Justice and the Human Genome Project 110, 116-17 (1994) (citing H. Tristam Engelhardt, Jr., The Foundations of Bioethics (1986)). 
ceive of a better example of bad brute luck. ${ }^{171}$ Thus, with geneticallydetermined diseases, the only questions for the redistribution-minded policymaker are how much redistribution is appropriate and what is the best tool for doing the job. The first question we again leave unanswered. It is the second question that is the main focus of this Section, and we conclude that there are a number of reasons to prefer redistributing through the legal rules to redistributing through taxand-transfer rules. The most difficult question will be what to do, as a matter of redistributive policy, about what we call "multi-factorial" diseases: Diseases that are caused partly by an individual's genetic makeup and caused partly by the individual's informed, voluntary choices, such as cancer or heart disease.

\section{The Easy Cases: Genetically-Determined Diseases}

Before we take up the hard cases, however, we begin with the easy ones. Assume that some high-cost diseases are determined entirely by an individual's genetic make-up. With respect to such diseases, in other words, the individual's behavior-her choices regarding how much or what to eat or whether to exercise or where to live-will have no effect on her likelihood of getting the disease or how severe the symptoms will be. Huntington's Disease is a good example. It is a horrible neurological disease caused by a defect in a single gene.

For those who have the defective gene, once the symptoms begin to appear (between the ages of 35 and 45), their health grows steadily worse, causing them to incur enormous healthcare costs over a period of 15 or so years and ultimately leaving them unable to care for themselves. Moreover, the nightmare ends with the patient suffering an inevitably premature and painful death. ${ }^{172}$ There is no known cure for Huntington's Disease, and those with the defective gene can do nothing to reduce (or increase) their likelihood of contracting the disease. With such purely genetically-determined diseases, there is an obvious argument under our framework for transferring money from those who do not have the gene to those who do. ${ }^{173}$

171 An equally strong case for redistribution, however, can be made with respect to diseases (or any source of higher-than-average expected lifetime costs) that are caused entirely by environmental or social circumstances that are beyond an individual's control.

172 Gwen Terrenoire, Huntington's Disease and the Ethics of Genetic Prediction, $18 \mathrm{~J}$. Med. Ethics 79, 79 (1992) (describing the disease).

173 But see Richard A. Epstein, The Legal Regulation of Genetic Discrimination: Old Responses to New Technology, 74 B.U. L. Rev. 1, 5 (1994) [hereinafter Genetic Discrimination] ("no wealth transfer to victims of Huntington's Disease could ever hope to equalize their positions in life."). 


\section{a. Choosing the Optimal Redistributive Policy Instrument}

The next important question, then, for the redistribution-minded policymaker is what redistributive policy instrument is best suited to reduce this type of inequality. Again, the framework of this Article suggests a comparison of the two general approaches-legal rules and tax-and-transfer rules - to determine which has a comparative advantage at redistributing with respect to this source of inequality. The legal-rule approach, for example, might entail a nondisrimination norm. It might prohibit insurers from taking the Huntington gene into account in their underwriting processes-that is, the processes by which insurers determine whether and on what terms to insure a particular individual. Similarly, the nondiscrimination rule might prohibit employers from using such information in their decisions concerning whether to allow particular employees to participate in employer-provided health, disability, or life insurance plans. ${ }^{174}$ Put more generally, insurers and employers would be prohibited from discriminating on the basis of genetic information. For example, they might be prohibited from requiring applicants to submit to genetic testing, or they might be forbidden to condition insurance coverage or employee benefits on the provision of genetic information.

The tax-and-transfer approach, by contrast, would entail no nondiscrimination principle. To the contrary, it explicitly would allow insurers and employers to use genetic information in the underwriting process, which would exacerbate the inequalities presented by the presence of genetically-determined diseases, as those with Huntington's Disease, for example, would find themselves wholly unable to find affordable health insurance. Then, under the tax-and-transfer re-

174 The concept of underwriting primarily is associated with the sale of individual insurance policies, that is, policies sold by an insurer to cover the risk of a particular individual person or business. And it is in the underwriting process for individual health, disability, and life insurance policies that insurers would take into account specific genetic information about individual risk characteristics. Insurers, however, also sell insurance policies to groups, such as in the most common case of employer-provided group health, disability, or life insurance. Sometimes employer-provided group insurance actually is insured with an insurance company (that is, the employer shifts its employees' health risks to an insurer for a premium), and sometimes it is self-insured by the employer. Either way, with group insurance, the insurer or employer-qua-insurer has less of a need for individualized risk information than in the case of individual insurance, because there is less of an adverse selection problem. In fact, group insurers for the most part do not seek genetic information from their insureds, but instead insure everyone in the group on largely the same terms. Thus, as we point out below, with respect to group insurance, there already is redistribution from the genetically better off to the less well off. As we argue, however, this sort of cross-subsidization may not remain stable if science progresses to the point where insurers (including group insurers) with a low-cost genetic test, definitively can determine that particular individuals have a much higher-than-average likelihood of contracting certain high-cost diseases. 
distributive approach, either a tax-financed subsidy would be paid to those who have the disease-related gene or the government itself would become the insurer (or healthcare provider) of such individuals.

A definitive determination of which approach would be optimal (which would strike the best balance between efficiency and distributional concerns) would require a considerable amount of empirical evidence. We argue, however, that the case for some version of the redistributive-rule approach in this setting is stronger than the critics of such antidiscrimination insurance rules have recognized. ${ }^{175}$ In addition we point out that those who have been most strident in their calls for legal rules prohibiting insurers and employers from using genetic information on distributive-justice grounds largely have failed to recognize that the key issue is not one of fairness per se, but one of comparative institutional advantage.

To understand the efficiency and distributive tradeoffs presented by the use of nondiscrimination rules, we first review some basic principles of insurance economics in order to understand why insurance companies have an economic incentive to use genetic information and to see the efficiency benefits of allowing them to do so. First, consider the insurance concept of risk classification. Insurers have an economic incentive to classify or segregate individuals into relatively narrow risk pools. Put differently, it is in the nature of a competitive insurance market that insurance companies will be induced to charge each individual insured a premium that approximates that insured's expected costs. Economists sometimes (and insurance companies frequently) refer to such premiums as "actuarially fair" premiums. If an insurer fails to price its policies actuarially fairly, other insurers will compete away the first insurer's business. And here's the kicker: Genetic information about individual insureds has the potential to enable insurers to make accurate and low-cost estimates of those insureds' expected costs and hence to facilitate more accurate pricing of individual policies.

Second, genetic information can help insurers combat the wellknown insurance problem of adverse selection. ${ }^{176}$ Adverse selection is the tendency for relatively high-risk individuals to purchase insurance. It occurs when insurers cannot distinguish high-risk from low-

175 See, e.g., Colin S. Diver \& Jane Maslow Cohen, Genophobia: What Is Wrong With Genetic Discrimination?, 149 U. Pa. L. Rev. 1439, 1468 (2001) (arguing that genetic information, if available to both the insurer and the insured, would increase the overall efficiency of group insurance markets).

176 In the case of multi-factorial diseases, genetic information also may help insurers overcome the other principal problem facing insurance markets: moral hazard. We discuss this issue at text accompanying note 182 . 
risk individuals and so must charge the same premium to all. Highrisk individuals (who know they are relatively high-risk) select into insurance pools to benefit from the cross-subsidization, causing premiums for everyone to rise eventually. This process can result in lowrisk individuals reducing their level of coverage or dropping out of insurance markets altogether, which produces an overall sacrifice of social welfare given that low-risk individuals are assumed to be risk averse and would prefer to be insured.

Thus, from the perspective of the insurance company, it is entirely fair and appropriate for insurers to charge premiums that approximate expected costs as closely as possible. In fact, in state court regulatory disputes over whether a given insurance company's rates are unfairly discriminatory, insurance companies make precisely that argument, arguing essentially that fair insurance premiums in the regulatory context should be interpreted to mean only actuarially fair premiums. ${ }^{177}$ The parties on the other side of those ratemaking disputes, however, typically argue, precisely for the brute luck/endowment sorts of reasons mentioned in the Introduction, ${ }^{178}$ that the state law fairness requirement should prevent insurers from taking into account some factors that bear on an individual's expected costs. And precisely that argument has been made with respect to genetic information. As one commentator put the point: "Since one cannot choose one's genetic make-up, arguably there should be no duty to pay more for insurance because of a poor genetic make-up."179

In our view the debate about whether fairness or distributive justice requires insurers to take genetic information into account or to ignore genetic information somewhat misses the point. At least in the case of purely genetically-determined diseases, few would dispute that fairness or distributive-justice concerns call for something to be done about the unequal allocation of the costs of those diseases in an unregulated insurance market. But the question, again, is what is the best approach. Which institution - the legal system or the tax-and-transfer system - has the comparative advantage in doing this sort of redistribution? The proponents of restrictions on insurers' use of genetic testing do not grapple with the fact that the important debate is not really about whether to redistribute with respect to such measures of

177 See, e.g., Hartford Accident \& Indem. Co. v. Ins. Comm'r, 482 A.2d 542 (Pa. 1984), excerpted and discussed in Kenneth S. Abraham, Insurance Law and Regulation: Cases and Materials 125-35 (3d ed. 2000).

178 See text accompanying notes 1-40.

179 Eric Mills Holmes, Solving the Insurance/Genetic Fair/Unfair Discrimination Dilemma in Light of the Human Genome Project, 85 Ky. L.J. 503, 563 (1996). In other parts of his article, Holmes explicitly invokes Rawls as a justification for imposing such limitations on insurance companies. Id. at 577. 
well-being, but how best to do it. ${ }^{180}$ And to answer that question, we return to the two questions we posed above with respect to income inequality: Which institution (the legal system or the tax-and-transfer system) is the best proxy observer with respect to disease-related genes? And which system is the best redistributor with respect to those genetic differences?

\section{b. Exploiting the Benefits of the "Invisible Redistributive Hand" of the Market}

As to the best-proxy-observer question, there is a sense in which the legal system has a distinct advantage over the tax-and-transfer system, an advantage unaddressed in the debates concerning insurers' use (and proposals to restrict their use) of genetic information. This advantage is inherent in the redistributive legal rule in question: A rule that prohibits insurers from using genetic information in their underwriting processes does not actually require that the relevant proxy be observed at all. The whole idea, in fact, is to prevent the proxy from being observed.

Of course, there would be administrative costs associated with enforcing the nonobservation rule; the policymaker would have to determine how much to spend on enforcement and what penalties to impose on noncompliant insurers. But there would be no expense

180 Most proponents of restrictions on insurers' use of genetic information fail to address the issue as one of comparative institutional advantage. They frame the question instead as whether justice or fairness principles requires such restrictions or not, rather than what is the best institutional approach if justice requires redistribution from the better off to the worse off. See, e.g., Daniels, note 170, at 132 ("[A]lthough [with genetic information] we may better predict which individuals are prone to certain diseases, and thus which individuals are worse insurance risks, justice requires that we not use this information in ways that make it more difficult for such people to obtain appropriate health care."). Even in one of the most comprehensive treatments of the genetic discrimination/insurance underwriting question, the author explicitly deemphasizes the comparative institutional question. Holmes, note 179 (surveying arguments for and against allowing insurers to use genetic testing in the underwriting process, but explicitly deemphasizing the comparative nature of the analysis). Holmes gives almost no attention to the tax-and-transfer alternative and how it would fare against the redistributive-rule approach, which is the exclusive focus of his article. The one exception is an early footnote in his article, in which he notes that Richard Epstein has suggested a tax-and-transfer alternative approach, but then concludes that "a public taxation solution would not constitute 'insurance' and issues of underwriting health risks using genetic information would be irrelevant." Holmes, note 179, at 507-08 n.5. The footnote goes on to summarize briefly how public healthcare programs such as Medicare and Medicaid interact with private health insurance, but it never explains why Epstein's tax-and-transfer alternative proposal is "irrelevant." The lack of emphasis on the comparative nature of the insurance/discrimination question is typical among scholars writing on the subject. See, e.g., Deborah Hellman, Is Actuarially Fair Insurance Pricing Actuarially Fair?: A Case Study in Insuring Battered Women, 32 Harv. C.R.-C.L. L. Rev. 355 (1997); Leah Wortham, The Economics of Insurance Classification: The Sound of One Invisible Hand Clapping, 47 Ohio St. L.J. 835 (1986). 
necessary to determine which individuals have the gene and which do not. Under the tax-and-transfer alternative, however, the taxing authority would have to adopt some means of determining those individuals with the relevant gene.

In addition to being the better proxy observer, the redistributiverule/antidiscrimination approach has advantages when it comes to determining the amount of the redistributive transfer. (In terms of our framework, this can be understood as a version of the better redistributor question.) Under the tax-and-transfer approach, the policymaker would need to determine up front the precise difference between the expected lifetime health costs of those individuals who have the gene and the expected lifetime costs of those without the gene so that the amount of the tax-and-transfer payments could be set accordingly. Gathering such information is costly, and there is little reason to believe that the tax collector would be able to do this on its own. By contrast, under the antidiscrimination approach (where insurers are simply forbidden from discriminating on the basis of genetics), the amount of the redistributive transfer, in effect, would be determined by market forces via a sort of "invisible redistributive hand." While insurers would need to determine how much to charge everyone in the insurance pool (again, by law, being forced to charge the same amount to those who have the disease gene and to those who do not), they would not have to determine the precise portion of premiums attributable to the genetic difference.

Thus, over time, as insureds who have the gene begin to experience health-related expenses and receive health-related benefits, those costs naturally would be spread over the entire insurance pool, resulting in cross-subsidizing transfers from those without the disease gene to those with it. And the amount of the cross-subsidization attributable to the antidiscrimination rule automatically would reflect the differences in health-related costs among members of the insurance pool that are attributable to the morally arbitrary genetic characteristic. As a result, it would not be necessary for insurers or for the policymaker to make a separate, ex ante calculation of the appropriate amount of the redistributive transfer; cross-subsidization within the insurance pool and competition among insurers would produce something approximating the right amount of redistributive transfer. ${ }^{181}$

181 Perhaps the most plausible tax-and-transfer alternative to our redistributive-rule/antidiscrimination approach would be to use the insurance industry's comparative advantage at determining insured losses. Thus, if insurers were allowed to use genetic information and as a result created separate risk pools for those with the gene and for those without it, they would develop (as a result of competition over time) a relatively accurate measure of the relevant difference in economic well-being between the two groups attributable to the disease gene. (That is, if the only difference between two insurance pools is that one con- 


\section{c. Limitations and Objections}

This redistributive-rule/antidiscrimination approach, of course, has important limitations. For example, the invisible hand redistributive transfer just described responds only to differences in lifetime healthcare costs. It does nothing to respond to the noneconomic, psychic costs of Huntington's Disease, which a tax system could address. In addition the redistributive-rule/antidiscrimination approach presents special costs. First, we should assume that, as scientists identify more disease-causing genes, individuals would desire (and would get) access to that information about themselves. As a result, if insurers are not allowed access to that same information, adverse selection in the individual insurance market would occur. Individuals who discover that they have the disease gene would leap at the chance to buy what would be a heavily cross-subsidized insurance policy.

This phenomenon in turn would cause premiums to rise, and lowrisk insureds would tend to reduce coverage or drop out of insurance pools altogether, a result that would be nonoptimal from an efficiency perspective. How serious the adverse selection problem would be in the individual insurance market, however, would depend on a number of factors: what percentage of the population had the gene, how large the health costs associated with the gene were, and how large the particular insurance pools happened to be. If the gene were present in relatively few individuals, the adverse selection effect would be small, especially in larger insurance pools.

Adverse selection is much less of a problem with group insurance, which is the form that most health and disability insurance (and a con-

sists of individuals with a particular disease gene, the resulting differences in loss experience between the two pools will be a natural measure of the differences in economic wellbeing) differences attributable solely to the gene. And this information conceivably could be shared with the taxing-and-transferring authority, which would use it to determine the appropriate redistributive transfer. In essence, we would be privatizing the calculation of the appropriate redistributive transfer, which makes sense, given that determining the relative costs presented by different groups of individuals, this is what insurers do best. It is what keeps actuaries off the streets. In any event, if such a sharing arrangement could be made administratively feasible, we agree that it represents a plausible alternative to a nondiscrimination legal-rule approach. In fact, it might be even fairer because it spreads the costs among the entire population and not a specific insurance pool. If that is the ultimate conclusion (that is, the insurance market is used to gather the relevant information and the tax system is used to do the actual redistribution), then inequalities with respect to diseaserelated genes would be one of those areas in which the optimal redistributive scheme is a mixed one-one system for proxy observing, the other for the actual redistributing.

Another alternative would be to allow private insurers to refuse to insure individuals who have particular disease-related genes and then to have the government insure those individuals. That would eliminate the need for the government to determine ex ante the difference in expected costs associated with the genes. It generally is believed, however, that the government is not typically as good as the private insurance industry at dealing with problems of moral hazard and adverse selection. 
siderable amount of life insurance) takes these days. With group insurance, the insurer relies less on traditional insurance underwriting practices (such as the use of health history questionnaires, blood tests, medical exams, and the like) and relies more on the fact that most insurance groups are relatively diverse in terms of their health-risk profiles. This is because an individual's decision to join a group, such as to become employed with a particular company, is a multi-faceted decision. And whether an individual has discovered that she has a particular medical condition would be only one of many factors bearing on the decision to take a particular job. By contrast, in the individual insurance market, an individual's decision to buy a health, disability, or life insurance policy would be hugely affected by that individual's perception of her own relatively poor health status. 182

Underwriting practices and group insurance, therefore, are alternative, though not mutually exclusive, responses to the problem of adverse selection. ${ }^{183}$ If adverse selection is, despite all of this, considered a serious problem, the final, though perhaps drastic, solution would be to make the purchase of insurance compulsory. ${ }^{184}$

A second problem with the redistributive-rule/antidiscrimination approach involves the concern that such an approach would tend to reallocate the extra costs associated with genetically-determined diseases in an arbitrary manner. For example, how those costs would be reallocated might depend upon whether individuals with the relevant gene have a tendency to work in particular industries or live in particular geographic regions of the country. If those individuals tend to gravitate towards certain jobs or certain areas, their gene-related costs would be borne primarily by the other members of insurance pools in those industries and parts of the country. ${ }^{185}$ Such an allocation is considered more arbitrary than, for example, allocating those extra costs

182 In fact, if health and disability insurers did nothing to prevent adverse selection (for example, if there were no medical exams required of applicants, and there were no preexisting conditions limitations on benefits), everyone could just go uninsured until they became ill, and only then buy insurance. That is adverse selection in the extreme and would render insurance markets unworkable.

183 Indeed, to the extent health, disability, and life insurance currently are provided through group plans that do not discriminate on the basis of genetics (as is the case for most of the health insurance market), cross-subsidization from individuals that are better off genetically to those that are less well off already occurs without any government intervention. As we discuss below, cross-subsidization within group insurance pools is perceived to be a problem only for relatively small groups.

184 Adverse selection is a problem only if individuals have a choice of when and how much insurance to purchase. If regulatory policy takes that choice away from them adverse selection ceases to be a problem.

185 Epstein, Genetic Discrimination, note 173, at 21 ("If workers with genetic defects tend to gravitate towards certain industries, professions, or geographic regions, then however neutral the anti-discrimination approach appears on its face, it will be heavily disproportionate in its impact."). 
across everyone in society, which a national tax-and-transfer approach in theory would be able to accomplish. In other words, although spreading the gene-related additional costs across the members of a particular insurance risk pool is an improvement over leaving those costs to the individuals themselves, it would be better still to spread those costs over the largest possible pool-all taxpayers in the United States. ${ }^{186}$

That complaint has some obvious merit. Whether the benefit of the additional cost-spreading would be worth the administrative cost of doing so and whether a straight tax-and-transfer approach would be the best means of additional cost-spreading are open questions. Again, there is the question of how big this problem really would be. If the amount of the additional insurance premium paid by the subsidizing member of the insurance pool under such a rule were relatively small on a per person basis, little would be gained by implementing a more comprehensive tax-and-transfer approach. The prevalence and sustainability of group insurance markets for health-related costs, which already produces cross-subsidization of the sort we advocate, suggests that the arbitrary reallocation problem may be relatively minor. ${ }^{187}$ More significant may be the problem of the uninsured. That is, to the extent that individuals lack health insurance, they obviously would not participate in-and could not contribute to or benefit from-the antidiscrimination approach. The solution to this problem may be greater subsidies for health insurance, perhaps coupled with mandatory coverage.

\footnotetext{
186 Epstein relies on a version of this point to argue in favor of a tax-and-transfer alternative to the problem of genetically-determined diseases. Id. at 20-21. He also argues that the tax-and-transfer approach is better because it produces an "overt subsidy" rather than a "covert subsidy" and because it presents a smaller risk of causing an explosion in healthcare costs than does the redistributive-rule approach. Id. The tax-and-transfer approach is not, however, Epstein's first choice. If he thought it were politically feasible, he would prefer what he calls "benign nonintervention," by which he means that the government should do nothing, a position that is entirely consistent with Epstein's libertarian philosophy. Id. at 20. For libertarians, distributive justice is a concept that should motivate voluntary charitable giving, not compulsory government redistribution.

187 We should not expect, however, that the trend toward group insurance (which typically does not use genetic information) would make the genetic discrimination issue moot. If individual health, disability, and life insurers are allowed to use genetic testing in their underwriting practices in a way that dramatically reduces their costs of identifying the relatively low-risk individuals, they eventually will begin to steal the relatively low-risk insureds away from group insurance pools, because they will be able to charge the low-risk members of the pool a relatively low premium. If that were to continue, group insurers might be forced to use genetic information as well. Thus, to some extent, the viability of the group insurance market depends on whether individual insurers are allowed to use genetic information. If there is to be an antidiscrimination rule, it must be imposed both on individual insurers and on group insurers.
} 
Thus, the ultimate solution to the arbitrary reallocation problem might be to facilitate the creation of relatively large, statewide, perhaps nationwide reinsurance pools-pools large and diverse enough to eliminate the concern about the costs of genetic diseases being reallocated insufficiently broadly. This could be done through government-subsidized or compulsory reinsurance programs. ${ }^{188}$ In fact, one of the most prominent and widely supported proposals in recent years for dealing with the problem of high health care costs borne by small insurance groups (groups that do not have the large numbers over which to spread the high costs attributable to individual group members who have particular diseases or conditions) involves the use of larger reinsurance groups that, through market mechanisms, could perform more efficiently the same sort of function that the tax-andtransfer system might accomplish. ${ }^{189}$

\section{The Hard Cases: Multi-Factorial Diseases}

If purely genetically-determined diseases present the strongest case for redistribution (and, we argue, a strong case for redistribution through a legal rule), the case is somewhat weaker, or at least more complicated, for multi-factorial diseases, those that are in part attributable to genes but also are affected by the individual's behavior. Those diseases (such as lung cancer, diabetes, heart disease, hypertension, and the like) represent the great bulk of health-related costs. The likelihood of contracting such a disease is greater for those with a particular gene than for those without the gene; however, their likelihood of contracting the disease also is (or may be) affected by other

\footnotetext{
188 See, e.g., Randall R. Bovbjerg, Reform of Financing for Health Coverage: What Can Reinsurance Accomplish?, 29 Inquiry 158, 163-70 (1992) (discussing subsidized and mandatory reinsurance programs); Holmes, note 179, at 661 ("A federal act could establish tax incentives for the states to mandate pools that offer comprehensive health insurance to all citizens, thereby fairly apportioning the social responsibility of providing health insurance to the uninsurable citizens.") (footnote omitted).

189 For example, during the health care reform debates of the early 1990's, the Health Insurance Association of America and the National Association of Insurance Commissioners together drafted model legislation addressed directly to this problem. See Mark A. Hall, The Political Economics of Health Insurance Market Reform, 11 Health Affairs 108, 108 (1992). The proposal included a number of provisions, including a commitment to provide health insurance to all willing purchasers at a reasonable price. Id. at 110 . One of the most important provisions, though, was the proposed system through which smallgroup insurers could spread the costs of "high-risk cases" over a larger reinsurance pool. Id. at 112 ("For commercial insurers, reinsurance is the most critical component of their reform proposals, for it provides a private market mechanism for the equitable distribution of high-risk cases."). The insurance industry argued that not only would reinsurance allow for a more equitable distribution of the high-risk cases but also that it would reduce the incentive of insurers to engage in surreptitious attempts to screen out risks that they do not want to insure. Id. at 115.
} 
factors such as environment and behavior. In other words, unlike with purely genetically-determined diseases, with multi-factorial diseases individual choice makes a difference.

It is common knowledge, for example, that if one refrains from smoking, adopts a low-fat diet that includes plenty of vegetables, fruits, and whole grains, and gets regular aerobic exercise, one can reduce one's risk of contracting cancer, heart disease, and hypertension, which are perennially among the leading causes of mortality and illness in the United States. ${ }^{190}$ By precisely how much one can reduce one's risk of getting these diseases through lifestyle choices, however, remains unclear. In any event, because of the choice element inherent in these diseases, there are both efficiency and distributional arguments that cut against trying to redistribute from those who do not have the genes to those who do, which means there are efficiency and distributional arguments for allowing insurers to use such genetic information in their underwriting decisions.

\section{a. Efficiency and Distributional Tradeoffs}

On the efficiency side, the question again is whether the use of such information by insurers would enhance their ability to combat adverse selection and moral hazard. As discussed above, adverse selection can be reduced by allowing insurers to use the genetic information insureds' have access to. As with genetically-determined diseases, insurers could charge higher premiums or refuse to insure those who have a cancer-related gene as well. In addition, if an insurer were to learn that an individual applicant had a particular multi-factorial cancer gene, the insurer then could reduce the moral hazard effect of insurance by offering the applicant a special premium discount (potentially above what is offered to the average insured) if she would agree to take certain steps to reduce her risk of contracting that particular cancer. Or the insurer might offer a special premium discount if the individual would agree to a higher-than-average deductible. ${ }^{191}$

190 Frank B. Hu \& Walter C. Willett, Optimal Diets for Prevention of Coronary Heart Disease, 288 JAMA 2569, 2575 (2002) (concluding that diets that include nonhydrogenated unsaturated fats, whole grains, fruits and vegetables together with regular physical activity, avoidance of smoking may prevent the majority of cardiovascular diseases); Tim Byers, Marion Nestle, Anne McTiernan, Colleen Doyle, Alexis Currie-Williams, Ted Gansler \& Michael Thun, Am. Cancer Soc'y 2001 Nutrition and Physical Activity Guidelines Advisory Comm., American Cancer Society Guidelines on Nutrition and Physical Activity for Cancer Prevention: Reducing the Risk of Cancer With Healthy Food Choices and Physical Activity, 52 Cancer J. for Clinicians 92 (2002) (recommending diet rich in fruits and vegetables, exercise and no smoking to prevent cancer).

191 Whether as a practical matter an insurance company can do much to affect an individual's incentives to avoid cancer or heart disease or other life-threatening and debilitating conditions is an empirical question. If an individual learns that she has a cancer gene 
Although the efficiency concerns seem to cut in one direction (that is, in favor of allowing insurers to use multi-factorial genetic information), the direction in which the distributive-justice arguments cut is less clear and may be in the opposite direction. As we have assumed throughout, the redistribution-minded policymaker should aim to redistribute in a way that reduces endowment-related inequality and, to the extent possible, in a way that has no effect on choice-related measures of well-being. ${ }^{192}$

The difficulty is that a multi-factorial disease presents a blended case. To some extent choice matters. An individual can choose whether to eat right, whether to exercise regularly, and, at some level, whether to smoke or whether to live next to a waste treatment facility. Insofar as choice plays a role, the redistribution-minded policymaker presumably should allow insurers to make distinctions-to charge different premiums and to offer different amounts or types of coverage-between individuals who have such genes and those who do not.

To the extent that genes play the major causal role, however, there remains a distributive-justice argument for limiting insurers' use of the information. How these competing concerns balance out depends on the circumstances of each disease. In cases where the gene plays the predominant causal role, perhaps the policymaker should forbid its use by insurers, and in cases where behavior and not the gene is the main causal factor, allow it.

Alternatively, the policymaker could allow insurers to use the genetic criterion but only to a limited extent. For example, insurers could charge those with the disease gene $20 \%$ of the increased expected costs associated with that gene. Such insurance pricing "bands" are also a common part of healthcare-financing reform pro-

and her doctor tells her she can reduce her risk of getting the disease by changing her diet and exercising more, one wonders whether there would be any additional incentive effect if her insurer also offered a premium discount if she followed the doctor's advice. Perhaps. Because the harmful effects of one's current consumption choices of ten do not manifest themselves until much later in life, some individuals may (myopically) ignore or underestimate those risks whereas, because individuals see and feel premium discounts in the here and now, they may have a somewhat greater effect. In any event, even insofar as insurance premiums can influence individuals to engage in less risky behavior, insurers always will face the problem of monitoring and enforcing the insured's compliance with the restrictions. For example, verifying representations by insurance applicants that they are nonsmokers is a costly enterprise.

192 In each of these cases, of course, there is some element of involuntariness or brute luck as well. Some individuals, because of the circumstances into which they were born, have little choice about what to eat or how much to exercise. This fact applies most obviously (though certainly not exclusively) to children, who of ten have little say in such matters. There are also voluntariness questions with respect to smoking, given the welldocumented addictive qualities of nicotine and given the fact that most long-term smokers begin smoking as children. 
posals. ${ }^{193}$ This middling approach has something in common with the approach we currently take with respect to income inequality. Recall that income inequality too is a blended concept, in the sense that it arises partly because of individual choice and partly because of individual endowment. So what do we do? We redistribute in such a way as to reduce but not eliminate income inequality. The same justification might be given for a limited use of insurance pricing bands. Precisely what those bands should look like is worthy of further study, but is beyond the scope of this Article.

\section{b. Implications of the Framework Beyond Disease-Related Genes}

Before leaving the topic of insurance underwriting, this Section considers a few other implications of our framework. First, note that our analysis applies to genetic information whatever its source-and not only to information from specific types of genetic tests. That is, if it is possible to determine that an individual has a particular geneticallydetermined disease, such as Huntington's Disease, without the use of a specific genetic test (for example, by asking whether the individual's parents had the disease), our framework would suggest disallowing insurers' use of that sort of question as well. ${ }^{194}$ It is not the genetic tests themselves that concern us; it is the insurers' use of the genetic information, whatever its source. ${ }^{195}$

\footnotetext{
193 E.g., Hall, note 189, at 110.
}

194 Assuming, of course, that the policymaker has determined that the adverse selection problem does not overwhelm the benefits of such a redistributive rule.

195 Epstein, too, thinks there should be no difference between the two sources of information; he thinks, however, that insurers should be allowed to take everything into account. Epstein, Genetic Discrimination, note 173, at 11-12 ("When an individual has knowledge that he is at risk of incapacitation, perhaps from family history, then full disclosure should be the norm. When the individual knows to a certainty that he is a carrier of the trait, from a reliable genetic test, the same is true. The principle does not change; all that changes is the information that must be disclosed."). Some states, such as New Jersey, protect all genetic information whether derived from family history or laboratory tests. E.g., N.J. Stat. Ann. \& 17B:30-12(e) (West Supp. 2002). Other states, such as Georgia, protect genetic information only if it is a result of laboratory tests. E.g., Ga. Code Ann. § 3354-2, -4 (1996). Insurance company officials have criticized the New Jersey approach on the grounds that it prohibits insurers from relying on sources of information that have been part of the underwriting process for decades. Small Business Access to Health Care Insurance: Hearing Before the House Comm. on Small Business, 107th Cong. 95 (2002) (testimony of Mary Nell Lehnhard, Senior Vice President for Policy and Representation at Blue Cross/Blue Shield Association). The Georgia approach, however, leads to odd results. For example, if a couple goes to have laboratory tests done and discovers that they are both carriers of cystic fibrosis, Georgia law prohibits insurers from using this information for underwriting purposes. In contrast, if this couple were to have a child with cystic fibrosis, insurers could safely infer that both parents carry this gene and can make use of this information for medical underwriting. 
Second, the framework of this Article has implications for (though it does not fully answer) the controversial questions concerning whether insurers should be able to use factors such as gender, race, and age in the underwriting process. All of those traits generally are considered aspects of a person's endowment, in the sense that a person generally cannot choose her gender, race, or age. Gender and race are genetically determined, and age is determined by date of birth. In addition, insurers of ten claim that various factors that affect insurable losses-lifetime healthcare costs, life expectancy, or even automobile collision expenses-correlate with gender, race, or age. ${ }^{196}$ Thus, because these characteristics are relatively easily observable, insurers want to use them in the insurance-underwriting process. ${ }^{197}$

Assuming for the sake of argument that insurers are correct about the correlation issue, the question for the policymaker from the perspective of our framework is to determine the extent to which the differences in correlated expected costs are themselves endowmentrelated or are choice-related. Take gender, for example. It is fairly uncontroversial that men and women on average pose different risks for insurers. ${ }^{198}$ Women on average live longer than men and at every age (again, on average) have a lower risk of dying. ${ }^{199}$ Insurers would like to charge women less for a given amount of life insurance than they charge men, but more for a given annuity. This makes economic sense, given that life insurance in its purest form is simply coverage against the risk of premature death (with respect to which risk women fair better than men), and annuities are essentially insurance coverage against the risk of outliving one's resources (with respect to which risk, from a purely economic perspective, men fair better than women, all else equal). The question for the policymaker is to what extent these differences between men and women are attributable to their respective endowments (genes, environment, social circumstances) and to what extent they are attributable to informed, voluntary choices. If the differences are purely endowment-related, insurers, should not be allowed to use gender in their insurance underwriting decisions. If it is purely choice-related, however, insurers should be allowed to use gender.

\footnotetext{
196 Robert H. Jerry, II, Understanding Insurance Law 102-09 (2d ed. 1996).

197 Race is obviously not as easy to observe as gender. And the definition of various racial categories can be contested. Still, to the extent race is observable and correlates with expected costs, insurers, in the absence of legal prohibitions, presumably would be interested in using classifications in the underwriting process.

198 Jerry, note 196, at 102 ("The statistical evidence is undeniable: men, on average, pose different risks for insurers than do women, on average.").

199 Id.
} 
If we assume that the differences are purely endowment-related, note that the effect of the prohibition would be to produce a transfer from women to men in life insurance pools and from men to women in annuity pools. That result is entirely consistent with our framework. Obviously, if we assume that all individuals would rather live their "expected" life span than die prematurely, a relatively low risk of premature death is a good thing; it makes a person relatively well off. Likewise, a relatively high likelihood of premature death is a bad thing. If we view the life insurance purchase from the perspective of the insured's dependents, the same conclusions hold: All else equal, the dependents are better off if the insured lives his or her expected life span. Along this dimension of well-being, then women on average are better off than men. And assuming this difference in well-being is purely endowment-related, a well-tailored approach to reducing that inequality would be to use a redistributive legal rule that prevents insurers from charging men more than women for life insurance and hence forces women to cross-subsidize men. 200

With respect, however, to the question of being able to provide for oneself and one's dependents via investment income, longevity (normally considered a good thing) is counterintuitively a negative. Put differently, whereas longevity in the life insurance market makes one better off, longevity in the annuity market makes one less well off. Along this dimension of economic well-being, then, men are better off than women. Here again, the cross-subsidizing transfer (from men to women) produced by forbidding the use of gender in annuity sales provides a relatively efficient system for reducing that particular inequality of well-being.

This justification for gender-blind insurance and annuity ratemaking is very different from previous justifications. For example, some commentators discussing gender rating have characterized the question as turning on whether an individual or a group perspective is taken. ${ }^{201}$ From a group perspective, under this view, allowing insurers to use gender is not "discriminatory" but "fair."202 Indeed, preventing an insurer from using gender would be discriminatory or unfair to women (in the case of life insurance) and men (in the case of annuities). ${ }^{203}$ As a group, women and men should get back roughly what they put into insurance pools. If, however, one sees the question as an

\footnotetext{
200 Again, as a result of the invisible redistributive hand of the competitive insurance market, the amount of the transfer would tend to be equal to the amount of the difference in economic well-being along this particular dimension.

201 E.g., Jerry, note 196, at 106. Others may favor allowing insurers to use gender if it benefits traditionally disadvantaged classes, but not if it works in the other direction.

202 Id. at $104-05$.

203 See id.
} 
issue of fairness to the individual man or woman applying for a particular insurance policy, allowing insurers to discriminate seems unfair. That is, it seems unfair on some level that an individual woman who is no different from a man in any respect other than her gender should pay more for a given annuity than a man would. ${ }^{204}$ From the perspective of our comparative-institutional-advantage framework, however, whether we choose the group or the individual perspective is irrelevant. Either way, there is an important difference in well-being between men and women: life expectancy or risk of death. And continuing with our assumption that this difference is purely the result (or at least largely the result) of differing endowments, there is a sound argument for redistribution.

An alternative view might say that whether insurers should be allowed to use gender in the underwriting process should be determined by whether, in the particular case, gender rating helps or hurts women. On this view, in the case of health and disability insurance (where women of a certain age pose higher average expected medical costs than do men of the same age due to women's potential maternity costs), 205 gender rating should not be allowed. For automobile insurance, however, since women on average have lower auto-accident expenses than men, ${ }^{206}$ insurers under this view not only should be allowed to use gender in setting premiums but should be required to. The idea is that, because women are less well off overall economically than men are, we should use the regulation of the insurance-underwriting process only to redistribute in a way that helps women. ${ }^{207}$

This conclusion is inconsistent with our comparative-institutionaladvantage approach. Our framework would suggest that, if women are less well-off than men along certain dimensions, we should choose the redistributive policy instrument best tailored to redress that particular inequality. Thus, if income inequality is the problem, the income tax-and-transfer system probably should be used. If the differences have to do with employment opportunities, employment-discrimination law may be the best-tailored approach. If, however, women are better off on average than men in some respect (such as, apparently, longevity), then that inequity also should be addressed, and again

204 See id.

205 Id. at 102.

206 Id.

207 This is consistent with Sanchirico's view. That is, as we understand Sanchirico, if it were determined that women were less well off overall than men, then every redistributive policy tool should be used to redress that overall asymmetry, irrespective of comparative institutional advantage. Presumably, in Sanchirico's world, women would get discounts at the supermarkets, when purchasing domestic airline flights, and the like. See Sanchirico, Efficiency Rationale, note 8, at 1009, 1018-31; see also text accompanying notes 163-65. 
through the institution with a comparative advantage for dealing with that sort of specific inequity. In a perfect world, then, where the redistribution-minded policymaker responds to all inequalities using the best observers and redistributors with respect to each type of inequality, the result should be the same as in the perfect welfarist approach. If we determined, however, that women have lower auto-accident expenses because they drive more safely for reasons that are choicebased, our framework would allow gender to be taken into account in auto insurance ratemaking.

Precisely the same sort of arguments could be made with respect to other risks that correlate with gender or age or race. If the differences in correlated risks are attributable purely to differences in genes, environment, or social circumstances, insurers' use of those criteria in the underwriting process should be limited or forbidden. If, however, there is some element of choice that contributes to these differences in risks, the analysis, as usual, is considerably more complicated, and a judgment must be made as to how much of the difference must be explained by pure endowment for the nondiscrimination rule to kick in. The same was true, recall, with multi-factorial diseases and, for that matter, with income.208 Thus, the fact that younger people tend

208 There are also separate, equally compelling reasons for forbidding discrimination by insurers on the basis of characteristics such as gender, race, or age. First, the policymaker may determine that insurers tend to get the correlation question wrong in the first place, that insurers wrongly assume (without adequate statistical foundation) that gender, race, or age correlates with relatively high expected costs. Although competition in the insurance market would tend to punish such mistakes, such market corrections are certainly no guarantee that gender, race, and age stereotypes will play no role in the insurance underwriting process. In addition, whatever the statistical insurance data reveal, it may well be that allowing insurers to discriminate on the basis of such characteristics perpetuates or reinforces invidious stereotypes and, on that basis alone, should be prohibited. Under current law in this country, for example, the use of race in insurance underwriting is strictly forbidden in any circumstance, no matter what type of insurance. Kenneth S. Abraham, Distributing Risk 92-95 (1986); Leah Wortham, Insurance Classification: Too Important to Be left to the Actuaries, 19 U. Mich. J.L. Ref. 349, 360-70 (1985). This uniform prohibition either could stem from a general consensus that the differences in insurable risks posed by blacks are entirely a function of endowment factors (primarily social and environmental circumstances stemming from hundreds of years of racism) or it could derive from a view that allowing insurers to discriminate on the basis of race, in and of itself, would contribute to invidious racial stereotypes. It is interesting that, by contrast, some states permit gender to be used for certain types of insurance underwriting. E.g., Telles v. Comm'r of Ins., 574 N.E.2d 359, 362 (Mass. 1991) (holding that insurance commissioner lacks authority to prohibit "fair discrimination" where it is undisputed that men have higher mortality rates); State Dep't of Ins. v. Ins. Services Office, 434 So.2d 908 (Fla. Dist. Ct. App. 1983) (holding that insurance department could not prohibit automobile insurers from discrimination based on gender so long as it is fair and not based solely on gender). In other states, insurers are required to gender-rate certain types of insurance. E.g., Cal. Ins. Code $\S 790.03$ (f) (West 1993) (ordinary life insurance and individual annuities). Some states, however, prohibit gender rating. E.g., Haw. Rev. Stat. § 431:10C-207 (1993) (auto insurance); Mass. Gen. Laws Ann. ch. 175E, § 4(d) (West 1998) (auto insurance); N.C. Gen. Stat 
to have higher auto-accident expenses than older people may be something that society would want to consider an issue of choice; that is, it may be that young drivers simply choose to drive more recklessly. If that were so, a redistributive rule forbidding age-rating in auto insurance would be inappropriate. No redistribution would be called for in that context; and hence insurers should be allowed to charge higher auto insurance premiums to young men.

\section{Summary}

We argued in this Section that, in the field of insurance law (which encompasses among other things the rules governing private insurance contracts), it may be possible to identify important sources of inequality - for example, inequality of lifetime expected health costs-that can be traced entirely or primarily to differences in genetic makeup. Such sources of inequality present a plausible case for redistribution from the better off to the less well off. Certainly, under our assumption of a policymaker interested in reducing brute luck-based inequality of well-being, redistribution on the basis of genetically-determined diseases presents a fairly compelling case, and some redistribution on the basis of unequal distribution of multi-factorial diseases also seems defensible-at least as defensible as income redistribution. More significant for the purposes of this Article, differential health status (especially but not only to the extent genetically-related) presents a situation in which a particular type of redistributive legal rule-a nondiscrimination rule-which produces intra-pool cross-subsidization, may be the most efficient means of effecting such redistributive transfers. ${ }^{209}$

This argument has implications not only for the laws governing private insurance contracts but also for the design of social insurance programs. Take, for example, the Medicare program. As currently designed Medicare produces a large amount of cross-subsidization from the healthy to the sick. This occurs because Medicare coverage is funded either through payroll taxes, which obviously make no distinctions among individuals based on health risks, or through non-

§ 58-3-25 (West 2000) (auto insurance); see also Mich. Comp. Laws Ann. § 500.2027(c) (West 1998) (no gender rating unless based on sound actuarial principles); Mont. Code Ann. § 49-2-309 (2001) (no rating for insurance based solely on gender).

209 In fact, one might argue that the amount of redistribution from those without disease genes to those with them via insurance cross-subsidization would be wholly inadequate. For example, a good case could be made that the endowment-based difference in wellbeing between a person with the Huntington's gene and the person without it, all else equal, is greater than the difference in their actuarial insurance premiums. Therefore, using the insurance system as the tool of redistribution should be thought of as a starting point. 
risk-adjusted premiums paid by participants. ${ }^{210}$ Either way, given that the payouts from the system come in the form of medical care (which obviously will be disproportionately valuable to the less healthy individuals, all else equal), the system results in a large transfer from the healthy to the sick. Thus, something like the nondiscrimination norm discussed above has long applied to publicly-provided social insurance. ${ }^{211}$ We do not argue here that such a norm is necessarily a good idea in the social insurance context. Our point is only that, if the policymaker were to decide that redistribution based on unequal health status were desirable, applying a nondiscrimination norm to a social insurance arrangement would likely be more efficient than the pure tax-and-transfer alternative, which presumably would entail some effort to assess a tax on healthy individuals and to make a transfer to unhealthy individuals. The nondiscrimination norm applied to a social insurance arrangement eliminates the need for the calculation. ${ }^{212}$

\section{B. Redistribution Through Tort Law}

The field of tort law contains a couple of especially compelling cases for our comparative-advantage framework for choosing the optimal redistributive policy instrument. In the following examples, a good case can be made that the legal system is at least the better proxy observer and is perhaps the better redistributor as well. The first example involves the sometimes controversial tort law doctrine that allows damages in personal injury lawsuits for nonpecuniary or noneconomic harms-sometimes called "pain-and-suffering damages." In this Section we argue that pain-and-suffering damages in

210 Medicare covers those aged 65 or older. It consists of "Part A" coverage for certain hospital-related expenses (such as inpatient care and skilled nursing home care) and "Part B" coverage for certain other medical expenses. Payroll taxes fund Part A and premiums paid by participants as well as general tax revenues fund Part B. Daniel Shaviro, Who Should Pay for Medicare? 21-39 (August 2001) (unpublished manuscript, on file with Tax Law Review).

211 Likewise, Social Security benefits-which include retirement benefits, some disability insurance coverage, as well as life insurance-are funded entirely through payroll taxes, which, again, are not risk-adjusted. Thus, the system produces transfers from the shortlived to the long-lived (insofar as Social Security provides benefits akin to private annuities) and from the long-lived to the (families of the) short-lived (insofar as Social Security provides benefits akin to life insurance).

212 A nondiscrimination norm rather than a tax-and-transfer approach also has drawbacks. For example, it is more difficult under such an approach for the policymaker to keep track of the total amount spent on redistribution. This fact will be a concern, however, only if the policymaker wants to take some of those "extra" dollars in Medicare taxes or premiums paid by the healthy individuals and spend it on something other than redistribution to the unhealthy - such as on tanks or roads. Imposing a tax on healthy individuals to fund a general public good (one whose benefits are enjoyed roughly equally by all taxpayers) seems more than a bit odd. It would seem to make more sense instead to use a more general tax base such as income or consumption or wealth. 
tort law can be defended entirely on distributive justice grounds, that is, as a transfer from the better off (the class of individuals who have not suffered a pain-and-suffering loss) to the class of individuals who have suffered from such a loss.

The second example is drawn from the existing redistributive rules literature, and it presents the question of how tort law should take account of the differences in individuals' inherent abilities to avoid accidents. For example, the disabled and the aged may be inherently less able to avoid accidents. If so, that fact should be taken into account in tort law for redistributive purposes, and it is a type of redistribution for which the tort system obviously seems better suited than the tax-and-transfer system.

\section{The Problem of Nonpecuniary Losses \\ a. Nonpecuniary Losses as a Question of Distributive Justice}

One source of inequality of well-being that society might care about is pain-and-suffering or nonpecuniary losses that arise out of personal injuries. ${ }^{213}$ The tort literature has provided two types of justifications for pain-and-suffering damages. The first involves the theory of corrective justice, which holds that pain-and-suffering damages are "a means of punishing wrongdoers and assuaging the feelings of those who had been wronged."214 The second type of justification is based in efficiency. More specifically, law and economics tort scholars have justified pain-and-suffering damages on deterrence grounds, arguing that optimal deterrence requires that potential injurers bear the full social costs of their conduct, including the nonpecuniary costs. ${ }^{215}$ In addition, some law and economics scholars have argued in favor of pain-and-suffering damages on insurance grounds. ${ }^{216}$ The insurance justification builds on the claim that rational, informed individuals in a hypothetical insurance contract would prefer to receive some or even

213 We use the terms "pain-and-suffering damages" and "nonpecuniary losses" interchangeably to include all of the various categories of nonpecuniary costs recognized by courts and the torts literature. For example, those terms comprise "noneconomic losses," "loss of consortium," "hedonic damages," "emotional distress," "mental anguish," "psychic damages," and "emotional losses," to name the most conspicuous ones.

214 Seffert v. Los Angeles Transit Lines, 364 P.2d 337, 345 (Cal. 1961).

215 William M. Landes \& Richard A. Posner, The Economic Structure of Tort Law 18687 (1987); Steven Shavell, Economic Analysis of Accident Law 133-34 (1987); cf. Samuel A. Rea, Jr., Nonpecuniary Loss and Breach of Contract, 11 J. Legal Stud. 35, 39 (1982) (nonpecuniary losses taken into account for calculation of optimal damages).

216 It sometimes is said that the two efficiency goals of products liability law are deterrence (giving optimal incentives to avoid cost-justifiably preventable accidents) and insurance (providing insurance to risk-averse parties for the unprevented accidents). See, e.g., Jon D. Hanson \& Kyle D. Logue, The First-Party Insurance Externality: An Economic Justification for Enterprise Liability, 76 Cornell L. Rev. 129 (1990). 
full coverage for their pain-and-suffering losses.217 Other law and economics scholars, however, while not disputing the deterrence rationale, have argued that the insurance argument, taken alone, cuts the other way. That is, they argue that rational individuals would not contract to receive such damages. ${ }^{218}$ Thus, the debate among legal economists regarding pain-and-suffering damages boils down to a sort of empirical question: Would rational individuals in fact demand painand-suffering insurance?

This Section provides a third justification for pain-and-suffering damages. Pain-and-suffering damages can be justified purely as a form of redistribution from the better off to the less well off. Based on the framework set forth in this Article, the redistribution-minded policymaker must answer two general questions with respect to nonpecuniary-loss inequality. First, is the inequality between those who have suffered nonpecuniary losses and those who have not the type of inequality that society cares to redress? Second, if the answer is yes, what is the best redistributive policy instrument or combination of instruments for dealing with this inequality?

Again, we do not have the answer to the first question. As in the case of genetic endowment or income, whether nonpecuniary-loss inequality is something that matters to people is a question for voters or politicians or maybe philosophers to answer. It seems uncontroversial that there is a large disparity or inequality in well-being between those individuals who have sincerely experienced severe nonpecuniary losses as a result of a personal injury and those who have not suffered such losses. Nonpecuniary losses are just as real as pecuniary losses. That conclusion is supported by the fact that, from a deterrence perspective, the nonpecuniary costs of accidents are uncontroversially considered to be of equal status with pecuniary costs. ${ }^{219}$ Both types of costs must be internalized in order to achieve efficient deterrence. And at least in cases in which the injured plaintiff is not contributorily negligent, the existence of "inequality" with respect to the distribution

217 E.g., Steven P. Croley \& Jon D. Hanson, The Nonpecuniary Costs of Accidents: Pain-and-Suffering Damages in Tort Law, 108 Harv. L. Rev. 1785, 1914-17 (1995) (concluding that consumers are likely to demand some level of pain-and-suffering insurance and therefore that tort law should provide some level of pain-and-suffering damages); Patricia M. Danzon, Tort Reform and the Role of Government in Private Insurance Markets, $13 \mathrm{~J}$. Legal Stud. 517, 533 (1984) (arguing that serious pain-and-suffering injuries should be awarded on the basis of predetermined schedules).

218 E.g., John E. Calfee \& Paul H. Rubin, Some Implications of Damages Payments for Nonpecuniary Losses, 21 J. Legal Stud. 371, 373, $402-03$ (1992); Robert Cooter, Towards a Market in Unmatured Tort Claims, 75 Va. L. Rev. 383, 392-94 (1989); George L. Priest, The Current Insurance Crisis and Modern Tort Law, 96 Yale L.J. 1521, 1546-47, 1553 (1987).

219 See Landes \& Posner, note 215, at 186. 
of nonpecuniary losses seems clearly unjust. But whether it is the sort of distributive injustice that requires a remedy is a question for the policymaker. ${ }^{220}$

\section{b. The Better-Observer/Better-Redistributor Questions}

As to the comparative-institutional-advantage question, the key issue is the problem of observability. For nonpecuniary losses to be considered real and hence a legitimate justification for compulsory redistribution, there needs to be some way of verifying that claims of nonpecuniary loss are sincere, not made up or exaggerated. Indeed, it is the task of verifying and measuring claims of nonpecuniary losses that distinguishes the redistributive role the tax-and-transfer system might play and the redistributive role the legal system (particularly, the tort system) might play.

Again, if the tax-and-transfer system is to play a major role in redistributing with respect to pain-and-suffering losses, policymakers would need to develop fairly precise and reliable proxies for nonpecuniary well-being that are easily observable, by which we mean difficult to falsify or exaggerate. If such proxies can be identified, the tax-andtransfer system offers the advantage of comprehensiveness-in the sense of taking into account the nonpecuniary well-being of everyone in society and not just those who happen to be affected by the tort system. If, however, the only plausible way of identifying, verifying, and measuring relative nonpecuniary well-being is to do a case-bycase factual analysis, the legal system naturally has a comparative advantage, although the scope of redistribution through the tort system (that is, the number of individuals in society who would be affected by this sort of redistribution) would be smaller.221

220 One possible way to answer this question would be to observe the market and see whether there is a demand for pain-and-suffering damages. We reject this option below. See text accompanying notes 224-36.

221 As with all redistribution through the tort system, some will argue that such redistribution, when compared with redistribution through the tax-and-transfer system, is haphazard in the sense of being underinclusive. Whereas the tort system applies only to those individuals who happen to be involved in accidents for which some third party can be held legally liable, the tax-and-transfer system can apply to everyone who suffers a similar nonpecuniary loss, though not caused by someone else's tortuous conduct. Our response to this sort of argument is simple: If individuals came equipped with reliable hedometers that the policymaker could use to make precise nonpecuniary well-being comparisons among individuals, then the more comprehensive tax-and-transfer approach would be all that we need. Such hedometers do not exist, however. All we have are proxies for the underlying psychological state of well-being. And, as argued in the text, if there are easily observable and reliable proxies that reveal this underlying state, the tax-and-transfer system can do a good job of redistributing with respect to those proxies. But if we want to redistribute in a more targeted, precise way, the legal system is superior. Just as the tax system is designed to do mass redistribution with respect to easily observable proxies for well-being, the legal 
What redistributive role might the legal system play here? The astute reader at this point should be able to predict where the analysis will go: If the tax-and-transfer system were limited to redistributing with respect to easily observable and measurable proxies for nonpecuniary well-being, the legal system-especially the tort system-could be used to perform a more modest though more precise redistributive function. The courts in a personal-injury tort suit could consider evidence of various sorts, including direct testimony from the plaintiff, regarding the sincerity and severity of the plaintiff's pain-and-suffering losses. Then the jury can make a determination as to whether, in this particular case, the individual has experienced nonpecuniary losses that should be compensated and can make a plausible estimate of how large those losses are.

This is what courts and juries have done in tort cases for years, though presumably for deterrence and corrective justice reasons rather than for distributive justice reasons. Considering these independent (nondistributive justice) rationales for pain-and-suffering damages in tort law, one reasonably might ask what is the point of offering an alternative distributive justice rationale.

For one thing, even if the other rationales for pain-and-suffering damages were found to be unpersuasive, the distributive justice argument would apply. For example, even if it were shown that imposing nonpecuniary losses on tortfeasors did not have the effect of optimizing potential injurers' ex ante incentives to avoid accidents (perhaps because of some cognitive bias on the part of potential injurers), requiring tortfeasors to pay such damages would still increase overall social welfare because of the distributive justice benefits of shifting resources from the nonpecuniarily better off to the nonpecuniarily less well off. Moreover, even if the other rationales for pain-and-suffering tort damages are considered persuasive, introducing an independent distributive justice rationale may make a difference.

Pain-and-suffering damages have been under assault for a number of years. Many scholars and policymakers have called for abolishing or severely curtailing such damages.222 A number of states have passed laws doing just that. ${ }^{223}$ Our point is that the distributional advantage of pain-and-suffering damages-shifting resources from the

system was made (in part) to do less comprehensive but more precise redistribution with respect to less easily observed characteristics.

222 E.g., Calfee \& Rubin, note 218, at 371; Priest, note 218, at 1546-47, 1553, 1587-90; Alan Schwartz, Proposals for Product Liability Reform: A Theoretical Synthesis, 97 Yale L.J. 353, 362-67 (1988).

${ }^{223}$ For a list of states that have limited the scope or magnitude of pain-and-suffering damages, see Heidi Li Feldman, Harm and Money: Against the Insurance Theory of Tort Compensation, 75 Tex L. Rev. 1567, 1567-68 nn.1-2 (1997). 
better off to the less well off-provides an additional justification (another weight in the balance) in favor of continuing to include painand-suffering damages as a part of standard tort recovery, or, in some states, reversing the trend toward capping or eliminating pain-and-suffering damages. This conclusion does not mean, however, that a redistribution-minded policymaker should not place limits on pain-andsuffering damages. It may turn out that the observability problem is so acute that such limits are necessary, both for deterrence and distributional reasons. Such a decision, however, should take into account not only the deterrence but also the distributional benefits of a caseby-case subjective pain-and-suffering analysis.

\section{c. The Lack-of-Consumer-Demand Objection}

One objection to our distributive-justice defense of pain-and-suffering damages involves the claim, made by Ronald Dworkin, that rational and informed individuals who are placed in some hypothetical ex ante bargain (akin to a Rawlsian "original position") would not want to purchase insurance for nonpecuniary losses. ${ }^{224}$ In a similar vein some law and economics scholars have gone so far as to claim that, if we look at the real world insurance market, we learn that individual consumers in fact do not "demand" insurance for nonpecuniary losses. ${ }^{225}$ This empirical claim is important because, if one adopts a "consumer sovereignty" notion of what constitutes society's preferences with respect to nonpecuniary losses, the absence of market-provided insurance for such losses suggests consumers do not value such insurance. Therefore, the argument goes, society should not compel the purchase of nonpecuniary-loss insurance in the form of pain-andsuffering tort damages.226

Our first response to this argument is simple: It strikes us as inappropriate to look to market evidence of existing consumer demand as a way of making judgments about redistributive policy. This is because all existing markets (including insurance markets) allocate resources according to individuals' willingness to pay. And individuals'

\footnotetext{
224 The original position and the veil of ignorance are terms that refer to a hypothetical state of the world in which people make basic decisions about the structure of society without knowing their own exact position in the world. These terms most frequently are associated with Rawls, note 9, at 17-22, although it was the economics Nobel Laureate John Harsanyi who first suggested something like the original position as a tool for making just societal decisions. John C. Harsanyi, Rational Behavior and Bargaining Equilibrium in Games and Social Situations 48-51 (1977). Dworkin also has used a version of this tool to construct a theory of justice. Dworkin, Equality of Resources, note 18, at 344.

225 Cooter, note 218, at 392-94; Priest, note 218, at 1546-47, 1553; Schwartz, note 222, at 362-67.

226 Priest, note 218 , at $1546-47$, 1553; Schwartz, note 222, at 362-67.
} 
willingness to pay obviously is a function of their wealth. Therefore, markets necessarily systematically discriminate against the poor. Indeed, that fact is what creates the need for a redistributive policy in the first place. ${ }^{227}$

This insight, of course, was not lost on Dworkin. His insurancebased theory of justice includes an assumption that, before asking the hypothetical insurance question, all individuals are given the same beginning material endowment. 228 Thus, Dworkin too recognizes that absent this initial egalitarian position, market outcomes cannot be used to set distributional policy.

But even if markets are seen as good indicators of a just allocation of resources, there are a number of other responses to the lack-ofconsumer-demand objection that have been offered in the torts and insurance literatures. First, some argue that in fact there are numerous examples of real world insurance for nonpecuniary losses, suggesting that there is indeed some "consumer demand" for such insurance. 229 Second, others point out that in areas where we do not see a demand for pain-and-suffering insurance it is because there are market impediments to consumers' demand. For example, consider the problem of imperfectly informed consumers. 230 Some have argued that this problem is especially troublesome with respect to nonpecuniary losses inasmuch as "there are an infinite variety of accidents that might occur, and each could lead to an infinite variety of nonpecuniary losses requiring an infinite variety of compensation levels."231 In addition, one could argue that noninjured consumers lack the information and the mental capability to perceive the post-injury state of the world and make correct (especially nonpecuniary) insurance decisions. ${ }^{232}$

Third, one also can argue that there are "supply-side" rather than "demand-side" impediments to a market for nonpecuniary-loss insurance. That is, the lack of certain types of nonpecuniary-loss insurance

227 This is true in our second-best real world in which poor individuals face substantial liquidity constraints and, therefore, cannot take out loans at competitive interest rates to express their preferences through purchasing decisions.

228 Dworkin, Equality of Resources, note 18, at 289.

229 For example, Croley and Hanson argue that accident insurance (which provides.coverage for death, dismemberment, and various other injuries) constitutes a form of pure pain-and-suffering insurance, given that all of the pecuniary elements of those losses tend already to be covered under other types of policies, such as life insurance and health insurance policies. Croley \& Hanson, note 217, at 1885-92.

230 See Alan Schwartz \& Robert E. Scott, Commercial Transactions 207 (2d ed. 1991) ("Consumers are relatively uninformed about the probability of defects and their potential costs.").

231 Croley \& Hanson, note 217, at 1846.

232 Ellen Smith Pryor, The Tort Law Debate, Efficiency and the Kingdom of the Ill: A Critique of the Insurance Theory of Compensation, 79 Va. L. Rev. 91, 111-16 (1993). 
can be explained as the result of various supply-side market failures. For example, consider the problem of asymmetric information, which can cause both ex ante and ex post moral hazard problems. That pain and suffering is difficult to observe and verify, of course, is exactly what makes it noncontractible. ${ }^{233}$ Asymmetric information also leads to adverse selection. Individuals who happen to know that they are more likely than average to suffer nonpecuniary losses would find insurance for such losses a relatively good deal, forcing premiums upward as such high-risk individuals adversely select into the insurance pools. Unfortunately, nonpecuniary adverse selection would be harder for insurers to combat through risk classification than some other types of adverse selection, precisely because nonpecuniary losses are so difficult (perhaps impossible) to observe ex ante.

In sum, for many of the same reasons that the tax-and-transfer system cannot respond to individualized pain-and-suffering claims, the private insurance market has difficulty offering insurance coverage for such claims. ${ }^{234}$ A conventional conclusion in the law and economics literature is that where there are market failures there is a need for government intervention. ${ }^{235}$ This conclusion about the private insurance market failures is important to our argument, because it provides a response to those who might argue that the best instrument for dealing with nonpecuniary losses is not the legal system or the tax-andtransfer system but the first-party insurance system. ${ }^{236}$ In fact, either

233 One way to overcome the impediments caused by the ex post moral hazard problem is to market insurance coverage with scheduled coverage amounts.

234 In some instances, however, when the moral hazard and adverse selection impediments are diminished, the market does seem to be able to provide pain-and-suffering coverage, again suggesting a certain level of consumer demand for such insurance. For example, Croley and Hanson argue that flight insurance is a form of pain-and-suffering insurance (because it is redundant of existing life insurance policies) that the market can offer because the moral hazard and adverse selection problems are minimal. Croley \& Hanson, note 217, at 1892-93.

235 See, e.g., Kaplow \& Shavell, Fairness II, note 1, at 15-38.

236 To this point in our argument, we have talked about the legal system and the tax-andtransfer system as the only available policy instruments for achieving distributive justice goals. Where, however, the source of inequality among individuals is some sudden, random event that occurs after birth (such as an accidental injury or an unexpected illness), welfarists scholars often will argue that no compulsory government redistribution is called for. Rather, such inequalities are dealt with best through the institution of insurance, where individuals decide for themselves whether, in effect, to use the insurance mechanism to redistribute from their noninjured or healthy selves to their injured or sick selves. Thus, for accidental losses, Dworkin's insurance analogy ceases to be an analogy; it is the real thing. And whether the government has any role to play here will be analyzed not in terms of distributive justice but in terms of which institution or set of institutions, public and private, provides the optimal form of insurance for a given type of risk. Thus, one way of understanding our distributive justice rationale for pain-and-suffering damages is as a reconceptualization of the efficient-insurance rationale. That is, we argue that the tort system (working together with liability insurance and first-party insurance system) is the 
the tax-and-transfer system or the private insurance market might be able to deal with nonpecuniary losses in circumstances in which there is an easily observable proxy for nonpecuniary well-being that is reliable and difficult to exaggerate or falsify. An example of such a proxy might be blindness or some other obvious handicap. If, however, the policymaker decides in addition that some individualized case-by-case redistribution with respect to nonpecuniary well-being is also desirable, the legal system or something very much like it would seem to be the only available instrument.

\section{The Problem of the "Accident Prone"}

In their debate over the proper role of redistributive legal rules, Sanchirico, as well as Kaplow and Shavell, discuss the example of the "accident prone," those individuals who, as the result of natural or innate inability, are especially incapable of avoiding harm-causing accidents. Sanchirico has argued that accident proneness is, in effect, another measure of ability to pay, which in turn is a proxy for wellbeing and thus should be taken into account in any redistributive policy. ${ }^{237}$ Kaplow and Shavell implicitly agree, although they question the use of the proxy when it would call for redistribution from the poor non-accident prone to the rich accident prone. ${ }^{238}$ We return to that debate shortly. For now, we assume that large inequalities with respect to accident proneness are a matter of redistributive concern.

In the abstract the accident prone may not seem to be a very sympathetic lot. Who can get excited about a redistributive policy that seeks to benefit the klutzes of the world, even if their klutziness is beyond their control? Fair enough. Society may decide that accident proneness should fall into that large category of sources of low well-being (such as being physically ugly or lacking a winning personality) that do not warrant a redistributive transfer. That conclusion, however, is not forgone. The accident prone, at least some accident prone, may be considered worthy of some sort of redistributive transfer. For example, consider individuals who are blind or wheelchair-bound or otherwise disabled or who are elderly and thus whose physical reflexes have slowed with age. All of such individuals arguably might be substantially more accident prone, all else equal, than is the norm. Observe that for this reason, for the purposes of this Article, one can treat the blindness, disability, and the like, as an independent source for egali-

optimal form of insurance for certain types of pain-and-suffering damages, namely, those that are difficult to observe and that require a detailed factual inquiry of the sort that courts have a comparative advantage in doing.

237 Sanchirico, Efficiency Rationale, note 8, at 1060-64.

238 Kaplow \& Shavell, Legal Rules, note 10, at 828-29. 
tarian concern, and not necessarily as a proxy for accident proneness or low welfare.

Granting this premise, the question then becomes how should society go about redistributing in favor of the accident prone. Again, we ask the same questions as before: Which system is the better observer with respect to accident proneness and which the better redistributors? This is an example of a source of inequality with respect to which the legal system almost certainly has a comparative advantage over the tax system. This comparative advantage can be seen in two different approaches to redistributing from the less accident prone to the more accident prone.

\section{a. The Across-the-Board Damage Adjustment}

One approach, suggested by Sanchirico, would be to make an across-the-board adjustment to the damages paid by tort defendants to tort plaintiffs. ${ }^{239}$ If the tort damage adjustment were used to redistribute solely with respect to accident proneness, presumably the adjustment would be downward, below the efficient level of damages, that is, below the level necessary to provide optimal deterrence. ${ }^{240}$ Such an adjustment would tend to redistribute in favor of the accident-prone as a class, because accident-prone individuals are, by definition, inherently more likely than the average person to be injurers in an accident that gives rise to a tort claim and thus are more likely to benefit from the downward adjustment. The benefit of this approach is that, by using the existing tort system and by making an across-theboard adjustment to damages, no special expense would have to be incurred to identify who is accident-prone and who is not. A simple downward adjustment in tort damages below the efficient level automatically would redistribute to the accident prone. ${ }^{241}$

As Sanchirico points out, such a redistributive rule would not be perfect. Its imperfections, however, are no different in kind or degree from the imperfections that can be found with any redistributive policy instrument, including the income tax. For example, determining precisely how much of an across-the-board, accident-proneness adjustment should be made to tort damages would not be easy. It would require an analysis of how much worse off than the average person

239 Sanchirico, Taxes, note 10, passim.

240 Id. at 804 . As discussed more fully below, Sanchirico (wrongly, in our opinion) seems to back off from the view that tort damages should be adjusted to alleviate accidentproneness inequality. Rather, he takes the position that, if income turns out in some sense to be the "dominant" measure of well-being, then tort damages should be income-adjusted rather than accident proneness-adjusted.

241 Kaplow \& Shavell, Legal Rules, note 10, at 828-29. 
the accident-prone person tends to be. But that sort of analysis is no different from the sort of analysis necessary to determine how much income redistribution would be appropriate. ${ }^{242}$

One also might argue that Sanchirico's accident-proneness adjustment would involve a large degree of imprecision. Some of those who would benefit from the adjustment would not be accident-prone but would have caused the accident and become tort defendants because of their own choices, such as the choice not to invest in accident avoidance. But again, there is always this sort of imprecision when using any proxy for well-being. Although the idealized version of welfarist redistribution would be entirely endowment-sensitive and choice-insensitive, that ideal is impossible whenever we redistribute on the basis of proxies for well-being (which is always). ${ }^{243}$

\section{b. The Subjective Due Care Standard}

There is a second approach to redistributing with respect to accident proneness through the legal system that in theory would not involve a regulated-activity distortion; indeed it would not involve any distortion. This alternative, however, has a somewhat narrower application than does the across-the-board proposal. It would apply only to tort settings in which negligence is the efficient liability rule. To see this alternative, recall that the tort system, from an economic perspective, exists primarily to serve the function of minimizing the costs of accidents, including the costs of avoiding accidents. ${ }^{244}$ According to the standard economic analysis of liability rules, for certain classes of cases the optimal liability rule is a negligence rule, a rule that holds the injurer liable only if she failed to take "due care" in avoiding the accident. ${ }^{245}$ If the courts define the negligence standard efficiently and apply it properly, it will give potential injurers the incentive to invest efficiently in accident avoidance-that is, it will give them an

\footnotetext{
242 Sanchirico, Taxes, note 10, at 808-10.

243 That is certainly true with respect to income redistribution. Some high income individuals are rich primarily because of their superior natural endowment or because of luck more generally (for example, inheritance); others are rich primarily (or at least to a greater degree) because of their choices to work hard and apply their relatively modest gifts. Nevertheless, we do not hesitate to use income as a redistributive proxy for well-being.

244 Guido Calabresi, The Costs of Accidents 26-31 (1970).

245 The negligence rule is capable of optimizing the potential victim's care and activity levels and the potential injurer's care level, whereas a strict liability rule is capable of optimizing the injurer's care level and activity level and the victim's care level. Thus, except in certain cases, neither rule can optimize the activity levels of both parties. The standard conclusion is that the choice between a negligence and a strict liability rule, from an economic perspective, should turn on which activity level is more important to regulate. E.g., Shavell, note 215 , at 29 . A negligence standard will be optimal when the victim's activity level is the most important.
} 
incentive to invest in care up to the point at which the next dollar invested in care equals the gains in accident cost reduction.

One important part of defining the efficient negligence standard is the potential injurer's "cost of taking care," that is, what it costs a potential injurer to take the care-level steps necessary to avoid a particular type of accident. ${ }^{246}$ As it turns out, if a particular individual's cost of taking care is lower than average, the optimal level of care for that person would be higher than for others, because it is efficient (it saves resources) to ask more from that person in the way of investments in care. Likewise, if a particular individual has a higher-thanaverage cost of taking care, the optimal care-level standard would be lower. Hence, "it may be desirable for a young, able-bodied [lowcost-of-care] person to clear a sidewalk of ice, but undesirable for an elderly [high-cost-of-care] individual to do so."247

Ideally, therefore, from a deterrence perspective, if it costs a court nothing to gather information concerning each individual's particular costs of care, the negligence standard would be finely tuned in each case to fit the individual circumstance of each tort defendant. ${ }^{248}$ Thus, as Shavell illustrates, "[i]f courts can distinguish the young and ablebodied person who can readily clear a sidewalk of ice from the elderly person who cannot, the first but not the second should be found negligent for failing to clear ice." 249 This subjectively defined due care standard is understood to be desirable on efficiency grounds.

This concept of "cost of care" is similar to what the redistributiverules literature means by accident proneness. Both concepts apply to something like an individual's ability to avoid accidents. Therefore, it can be shown that the ideally efficient negligence regime also would provide an ideally targeted redistributive mechanism. Under the subjective due care regime, more is expected from high-ability people than from average- or low-ability people. In addition, there is no double-distortion problem: There is no work-leisure distortion, because the redistribution is not income-based; that is, reducing work effort has no effect on one's likelihood of being held liable in tort. And there is no regulated-activity distortion. To the contrary, as the example from Shavell made clear, this type of subjective care-level standard enhances rather than detracts from efficiency. Indeed, it is essential to achieving optimal care levels under a negligence regime.

\footnotetext{
246 Shavell, note 215 , at 73 ("The socially optimal level of care of a party will generally depend on his cost of taking care ....").

247 Id. at 74.

248 Landes \& Posner, note 215, at 123 ("If the costs to the courts of informing themselves about an individual's ability to avoid accidents were zero, they would set a different due care level for each individual in every accident case.").

249 Shavell, note 215 , at 74 .
} 
Where might such a rule come into play? Consider the run-of-themill negligence case, for example, the residential slip-and-fall case of Shavell's hypothetical. Should the elderly or disabled be held to the same level of care in maintaining the safety of their sidewalks, or other aspects of their homes, as other individuals? Or should the elderly or disabled individual who attempts to assist someone who is drowning or choking be held to the same standard as those who are younger or, in a relevant respect, more able to assist in such situations? From an efficiency perspective (according to the standard analysis), a rule that imposed such a burden on the less able (or more accident-prone) would be inefficient, inasmuch as, on the margin, it would induce individuals to invest super-optimally in accident avoidance-perhaps shoveling snow to the point of inducing a heart attack or perhaps discouraging them from ever even attempting the Good Samaritan role. What is more, there are distributive justice reasons for the same conclusion: Imposing the same duty of accident prevention on all individuals irrespective of their innate ability to avoid accidents is arguably inconsistent with widely shared notions of distributive justice. It would be like a head tax, without the lump sum efficiency benefits.

It is interesting that existing tort law in this country already seems to be responding to this observation. As all first-year law students learn, according to the general rule in most jurisdictions, tort defendants are held to the standard of an average man or woman placed in the particular accident situation..$^{250}$ Such a rule invovles relatively little redistribution. There are, however, a number of exceptions. For example, the care-level burden placed on the blind, the lame, or the infirm is sometimes less than on the average person; ${ }^{251}$ whereas relatively more sometimes is expected of those with special strength, size, knowledge, or skill. In cases involving children, courts typically take into account the level of intelligence, strength, and maturity of a reasonable child. ${ }^{252}$ Likewise, historically there have been tort cases in which old age was taken into account as well.253

\footnotetext{
250 E.g., Restatement (Second) of Torts $§ 283$ (2002).

251 E.g., Breunig v. Am. Family Ins. Co., 173 N.W.2d 619 (Wis. 1970) (mental delusions); Fletcher v. City of Aberdeen, 338 P.2d 743 (Wash. 1959) (blindness).

252 E.g., Restatement (Second) of Torts § 283(a) (2002).

253 E.g., Johnson v. St. Paul City Ry. Co., 69 N.W. 900 (Minn. 1897); Roberts v. Ring, 173 N.W. 437 (Minn. 1919); Daniels v. Evans, 224 A.2d 63 (N.H. 1966). In general, however, if a high-cost-of-care (accident-prone) person is engaged in certain extremely risky activities, such as driving a speedboat, no discount is given. The general due care standard applies in such cases. See, e.g., Dellivo v. Pearson, 107 N.W.2d 859 (Minn. 1961). Applying the general reasonable person standard to accident-prone individuals in such cases is akin to applying strict liability, which makes sense because these are cases in which strict liability-and its optimizing effects on injurer activity levels-is called for.
} 
In addition to using such rough proxies for accident proneness (which is a type of class-based redistributive rule), the redistributionminded policymaker might decide to take the next step. That is, if it turns out that society were really serious about redressing accidentproneness inequality per se (and were willing to spend money to do it), courts hearing negligence cases in each case could attempt a more thorough and subjective analysis of the accident proneness of the particular tort defendant.

Such an individualized accident-proneness analysis (a type of casespecific redistributive rule) would entail additional administrative costs, as commentators have recognized when discussing the efficiency (deterrence) benefits of such an analysis.254 And at some point, of course, the costs of further precision would outweigh the benefits. In fact, some of the same legal economists who have described the deterrence benefits of a subjective negligence standard have concluded that a truly subjective analysis would not be cost effective. ${ }^{255}$ Even if the costs of additional precision would at some point exceed the benefits, it certainly is not clear where that point is or whether we are anywhere near that point now. Moreover, once the distributional benefits of a rule are taken into account, it may be that the question of the optimally subjective reasonable person standard should be revisited.

In sum, our argument is this: The additional precision that would come from an individualized subjective negligence analysis not only would produce efficiency gains (as traditional economic analysis has long recognized) but also would produce distributional gains that previously have not been recognized.256 A similar sort of argument ap-

254 E.g., Landes \& Posner, note 215, at 123-31.

255 Id. at 124.

256 A potential critique of this suggestion takes the following form: What about activity levels? Requiring disabled or elderly potential injurers only to act as a reasonable disabled or elderly person would act (taking their higher costs of care into account) would have the effect of inducing such high-cost-of-care individuals to engage in excessive levels of accident-causing behaviors. The most extreme example involves the blind driver. Should a blind person be held only to the driving standards of a reasonable blind driver? This is, of course, absurd. But recall the premise of this analysis: It applies only in situations in which the negligence standard is the appropriate liability rule, that is, when the injurers' activity levels are not the key deterrence variable. Obviously, the key deterrence variable for blind drivers is the injurer's activity level: Blind people, at least under current automotive technology, should not be driving at all. Indeed, it is illegal for them to drive. (Recall the eye test from when you last renewed your license.)

But take a less extreme example, which presents a harder case: elderly drivers. The elderly can get a driver's license. Although some might argue that this is a bad idea, it is still the law, even though people above a certain age almost certainly have slower reflexes, poorer vision and, in extreme cases, somewhat impaired judgment. Nevertheless, society has determined that the sort of personal mobility that accompanies the right to drive is so important that elderly individuals must not be systematically deprived of it. Given that background rule, what should the due care standard be for elderly drivers? Arguably, it 
plies to efforts to fine tune the progressivity of the income tax. That is, it is well known that, if, in an effort to increase the distributional "fairness" of the income tax, we adopt an system that has a steeply progressive rate structure consisting of numerous tax brackets on different levels of income, we also will increase the administrative costs of complying with and enforcing the tax laws. We also increase the precision with which we can achieve our distributional goal of allocating tax liability on the basis of ability to pay. Thus, there is a tradeoff between accuracy and administrative cost. Where the line is drawn depends in part on how much accuracy means to us, that is, how much value accuracy receives in the social welfare function. The same goes for the question of redistributive legal rules: How much we are willing to pay (in the form of lost efficiency or greater administrative costs) to fine tune a redistributive rule depends on, among other things, how much we care about the type of inequality in question.

How would the presence of insurance affect the application of these two tort-based efforts to achieve distributional fairness with respect to accident proneness? Under Sanchirico's across-the-board damage adjustment, the insurance system would facilitate the redistributive function, assuming insurance companies can do a reasonably good job of risk-adjusting their premiums. Assume for the moment that everyone has full liability insurance, and assume that insurance premiums are perfectly risk-adjusted so that each individual's insurance premiums always represent that person's expected losses. In that scenario the adoption of an across-the-board downward adjustment in tort damages, compared with a world without such a rule, would tend to reduce the liability insurance premiums of those who present a relatively high risk of causing an accident (a class in which the accident prone would be overrepresented) and would leave unchanged the premiums of the non-accident prone.

should be a reasonable elderly driver standard, for the reasons already discussed. Such a rule would be efficient, from a care-level perspective, and it would be distributively just (again, if we wish to cause a transfer from the less accident prone to the more accident prone). The point is that, with respect to some types of activities and potential injurers, the activity-level question may be dealt with best through licensing or other types of direct regulation, leaving the care-level regulation (and redistribution) to the tort law.

All of this is not to say that it would be inconsistent with distributive justice for society, in some situations, to impose activity-level limits on various classes of individuals. For example, one could imagine a regime in which some classes of individuals were allowed to drive only in emergency situations, that is, situations in which society has determined that the benefits exceed the costs. Even then, the question about defining the appropriate due care standard would arise: With respect to the specific situations in which the activity itself is deemed to be cost-justified, should the potential injurer be held to a subjective or objective standard? Excessive administrative costs may suggest the latter, but efficient deterrence and distributive justice would cut in favor of the former. 
Thus, the accident prone, relative to the non-accident prone, would be made better off. To the extent insurance premiums are not riskadjusted at all, however, the desirable redistributive effect of the adjustment-from the non-accident prone to the accident prone-would be reduced. Everyone's liability insurance premiums would drop, regardless of whether they were accident prone or not. Simultaneously, everyone's first-party insurance premiums would increase by roughly the same amount as a result of the across-the-board downward adjustment in tort damages to make up for the reduction in the amount that first-party insurers could expect to get in subrogation suits against tortfeasors. ${ }^{257}$

In the real world then, assuming the existence of less-than-full and imperfectly-adjusting liability and first-party insurance, the redistributive consequences of an across-the-board downward adjustment in tort damages would depend on who tends to have which type of insurance and the relative degree of risk adjustment one sees in various types of liability and first-party insurance.

\section{c. Coordinating the Tort System With the Tax System}

We return now to the comparative institutional advantage question: Could the tax-and-transfer system redistribute with respect to accident proneness more efficiently than the tort system? If there are reliable measures of accident proneness that are also easily observable, the tax-and-transfer system may have an important redistributive role to play. For example, if it could be shown that disabled individuals or elderly individuals are more accident-prone (that is, have higher costs of care) than the average person, a transfer might be made directly to the disabled and the elderly, or they might be given a special tax deduction or credit, to redress this inequality. ${ }^{258}$

257 This conclusion assumes that the subrogation system works well, in the sense that first-party insurers generally are able to recover all of their payouts to insureds that are caused by the tortious conduct of third parties and that they (the first-party insurers) are able to predict these recoveries in advance in the calculation of the premiums they charge.

258 Kaplow and Shavell suggest something along these lines:

The importance of unobservability of klutziness is reinforced by considering a different case: people who are blind. Because the blind can be identified, it is possible to assist them directly, by lowering their income taxes or otherwise. Only if we could not tell who was blind would we need to resort to indirect (less well targeted and less efficient) means of assisting them, such as adjusting legal rules.

Kaplow \& Shavell, Legal Rules, note 10, at 829 n.18. Thus, Kaplow and Shavell argue that, where the relevant nonincome proxy for well-being is difficult to observe, we may want to use redistributive legal rules because the legal system is the better proxy observer, even though some inefficiency may result. Our argument in this Section is that, at least in some cases, the legal system can be used to redistribute with respect to nonincome proxies for 
Such an approach presumably would not produce a regulated-activity distortion, as tort rules could be set solely to achieve efficiency. ${ }^{259}$ The tax-and-transfer approach, however, would entail some loss of precision at least as compared to the individualized subjective reasonable person standard, depending on how accurate and targeted the accident-proneness proxies turn out to be. If, in contrast, there are no reliable measures of accident proneness that are also easily observable, tort law should play the major distributive role. ${ }^{260}$

\section{d. The Existing Debate Over Accident Proneness: Highlighting Our Independence Assumption}

Redistributing with respect to accident proneness has become a central point of contention in the debate between Sanchirico, on the one hand, and Kaplow and Shavell, on the other. Both Kaplow and Shavell and Sanchirico are working from within the traditional welfarist framework. Thus, for them, accident proneness is relevantnot as a measure of an independent source of inequality - but as a proxy for well-being, which, for the welfarist, is the one, true target of redistributive (or any) policymaking. They disagree, however, as to how the welfarist redistributor should approach accident proneness.

On the one hand, Sanchirico regards accident proneness as a sort of nonincome measure of individual ability to pay. ${ }^{261}$ Under Sanchirico's conception of accident proneness, then, those individuals who have the innate characteristics that make them relatively more "able" to produce income also will likely have characteristics that make them more able to avoid accidents. Hence, Sanchirico initially proposed the across-the-board downward adjustment in tort damages.262

Whether accident proneness is a good proxy for ability to produce income, however, is an open question. Obviously, some of the traits that facilitate income generation also will facilitate some level of accident avoidance, but there will be differences as well. For example, it might well be that those with the greatest ability to generate income, because they have mental capacities that are most highly valued in the marketplace, would not be those with the greatest ability to avoid ac-

well-being in ways that do not necessarily produce inefficiency but may actually enhance efficiency.

259 Moreover, such an approach arguably would be less haphazard than the tort-based alternatives; that is, it could apply to all accident-prone individuals and not just to those who happen to be involved in tort suits.

260 See Subsection IV.B.1.b.

261 See note 237 and accompanying text.

262 See discussion in Subsection IV.B.2.a. 
cidents, which arguably might require physical skills and reflexes that are less well remunerated in the niarket.263

This possibility leads to Kaplow and Shavell's main criticism of Sanchirico's accident-proneness analysis: They argue that redistributing from the less accident prone to the more accident prone can just as likely involve redistribution from the income poor to the income rich as the reverse. ${ }^{264}$ The result depends on whether accident proneness correlates positively or negatively with income, a question that Kaplow and Shavell admit can be answered only with additional empirical research.

Nevertheless, building on Sanchirico's example of a hypothetical world involving rich (though accident-prone) yacht owners and poor (though non-accident-prone) boat owners, Kaplow and Shavell suggest a plausible story in which accident proneness (or, to use their term, "klutziness") might correlate positively with ability to earn. In that case, Sanchirico's accident proneness-based redistributive rule would involve lowering tort damages paid by the income-rich yacht owners. Kaplow and Shavell suggest that this result is counterintuitive at best. ${ }^{265}$

Interestingly, Sanchirico seems to agree that such a result is counterintuitive, even perverse. ${ }^{266}$ In response, however, he insists that Kaplow and Shavell's yacht-boat analysis reflects a misunderstanding of his argument. His position, properly understood, is that redistributive policy should focus on making transfers from the better off to the less well off "overall;" and, if it happens that income (and not accident proneness) is considered the "dominant" measure of overall well-being in our society, we should adjust legal rules not on the basis of accident proneness but on the basis of relative income. ${ }^{267}$

Thus, if it turns out that yacht owners, though more accident-prone than boaters, are relatively income rich (and, again, income is the dominant measure of overall well-being), then tort damage awards against yacht owners should be adjusted upwards. The rich yacht owners would then be subsidizing everyone else. Sanchirico seems to be arguing, then, that Kaplow and Shavell's yacht-boat example in which the rich subsidize the poor is a red herring. If it is income ine-

\footnotetext{
263 Kaplow \& Shavell, Legal Rules, note 10, at 831-32.

264 Id. at 829-32.

265 Id. at 829-30.

266 Sanchirico, Efficiency Rationale, note 8, at 1034-35.

267 Id. at 1035 ("[I]f income were the dominant indicator of overall well-being, being income-poor would be closely identified with being less well-off overall, and, accordingly, the proper equity adjustment to all legal rules would tend to help the poor.").
} 
quality that we care about, legal rules can be made incomeredistributive. ${ }^{268}$

Therefore, both Kaplow and Shavell and Sanchirico suggest that redistribution from the less accident prone to the more accident prone would be unacceptable (or at least highly questionable) if it meant transferring from the income poor to the income rich. This conclusion derives from their welfarist approach and from their assumption that income is a more important measure of well-being than accident proneness is. That is, the redistribution-minded welfarist policymaker cares only about the unobservable characteristic of well-being; thus, income inequality and accident-proneness inequality are only proxies for inequalities of well-being. And if income is the more important proxy for well-being than accident proneness (that is, if rich but clumsy yacht owners tend to be better off overall than poor but nimble boat owners), then the welfarist redistributive policy would call for transfers from the high income to the low income (from yacht owners to boat owners), whatever transfer mechanism is used, although the transfer might be somewhat smaller than if the accident proneness proxy cut the other way.

We reach a different conclusion. First, we assume that different types of inequality can matter to a policymaker independent of other types of inequality. This is what we call our "independence assumption."269 Thus, when we say that if the redistribution-minded policymaker or society in general decides to do something to reduce the inequality of $X$ (be it accident proneness or pain-and-suffering losses or genetically-caused diseases or any other source of brute luck-based inequality of well-being), what we mean is that the policymaker has determined that that source of inequality is problematic, not as a proxy for well-being, but in and of itself.

Therefore, if we assume: (1) that accident-proneness inequality is a type of inequality that society cares about (a question on which we take no position); (2) that the tax system is best suited for dealing with income inequality; and (3) that the legal system is the superior redistributive policy instrument with respect to accident-proneness inequality, then there would nothing perverse or absurd about a redistributive tort rule that resulted in transfers from the less accident prone to the more accident prone, even if it meant transferring from the income poor to the income rich.

This conclusion follows from our comparative-institutional-advantage framework. Income inequalities that exist between the accident

${ }^{268}$ See Section III.C for a discussion of Sanchirico's defense of income-adjusted legal rules.

269 See note 31 and accompanying text (introducing our independence assumption). 
prone and the non-accident prone should be dealt with largely through the tax system (with potentially some modest role for legal rules, if the random-taxation argument holds up). Which system should be used to deal with accident proneness inequality is a separate question, a question to which the relative incomes of the accident prone versus the non-accident prone are irrelevant.

Although our comparative-advantage argument is strongest if we make the independence assumption (described above), it is not necessarily dependent on it. That is, our argument can be made from within the traditional welfarist framework as well. Under the welfarist framework, the only thing that should matter to the redistributive policymaker is the single concept of inequality of well-being and what the various proxies for well-being say about that type of inequality. This assumption, however, does not necessarily mean that every policy instrument should be adjusted with respect to every proxy for wellbeing. It still could be the case that the best approach is to have each policy instrument focus on the proxy for well-being for which that instrument has a comparative advantage at either observing or redistributing or both.

Thus, for example, redistribution with respect to the income proxy could be achieved solely through the tax-and-transfer system (if that system is deemed to have the comparative advantage with respect to that proxy); redistribution with respect to accident proneness could be achieved solely through the legal system; and so on-with no reason for each tool to address each and every proxy. The result would be that the overall redistributive system (including both tax rules and legal rules) would respond to differences in overall well-being as accurately as possible.

To see this point, contrast two hypothetical welfarist redistributive regimes. To simplify, assume that the only two proxies for well-being that the policymaker has are income and accident proneness, both of which can be expressed in terms of dollars, and that the only tools for redistribution are the income tax and the tort system. Imagine further that there are only two people in this hypothetical society, whose total well-being is the sum of the dollar value of the two proxies mentioned above. It is this total well-being the policymaker wants to fully equalize through the redistributive system. Assume that individual $A$ has $\$ 90$ of income whereas individual $B$ has only $\$ 10$ of income. Assume also that $A$ has $\$ 5$ and $B$ has $\$ 25$ worth of innate accident-avoiding capacity. Thus, initially $A$ 's overall well-being is $\$ 95$ (measured in terms of money) and $B$ 's overall well-being is $\$ 35$. In each case, the dollar figure represents the individual's relative well-being as measured by that proxy. Under these assumptions, the ultimate goal for 
the welfarist redistributor is to have $A$ somehow transfer $\$ 30$ to $B$. That would leave $A$ and $B$ each with $\$ 65$ of total well-being, as measured by the combination of these two proxies as valued in dollars.

But how to do this? One way would be to have the income tax system do all the work, effecting an income tax transfer from $A$ to $B-$ via deductions, credits, or whatever-of $\$ 30$. This result seems consistent with the Kaplow and Shavell model, although they do not take a firm position on how best to deal with accident proneness. Alternatively, the policymaker might use the tax system to transfer $\$ 40$ from $A$ to $B$, equalizing "dollars of income," and then have the tort system transfer $\$ 10$ from $B$ to $A$, equalizing "dollars of accident-avoidance ability." This approach is closer to what we have in mind.

The question is which is the better approach. First, observe that both approaches result in the equalization of overall well-being, as measured by these two proxies. In this example, we assumed that all of the information about which party had which level of each proxy was known by everyone and there were no inefficiencies associated with the transfers. In fact, however, information is costly, and, in our view, the tax system is better at gathering information about income, whereas the tort system is better at gathering information about accident proneness. Thus, if we decide to use the tax system to do all of the redistributing (for example, because of the haphazardness problem), ${ }^{270}$ we at least should use the legal system to gather the relevant information about accident proneness. In addition, we argue that there are efficiency reasons to redistribute through the legal system with respect to accident proneness-enhancements in deterrencethat would not exist if accident-proneness redistribution were done through the tax system.

Where does this leave Sanchirico's preferred option, which would call for adjusting both tools - taxes and torts-for differences in both proxies-income and accident proneness? Under either of the idealized regimes mentioned in the previous paragraph, it is not clear what the benefit would be of making both tools redistributive with respect to both proxies. If the income tax system can completely equalize with respect to income (that is, completely eliminate income differences) and accident proneness (the first situation above), there is no inequality left for the tort system to address.

If, however, one were persuaded by our comparative-advantage argument that income inequality can be handled best by the tax system, and the accident proneness inequality by the tort system, and the second approach from the example above was taken, all of the inequality again would be eliminated. Under neither of those scenarios (Kaplow

270 See Subsection III.B.2. 
and Shavell's and ours) does it seem to be necessary also to adjust the income tax for accident-proneness inequality or the tort system for income inequality. (Both $A$ and $B$ already have $\$ 50$ total; what redistribution is left to be done?)

Sanchirico's world, of course, is one of incomplete information in which the different redistributive tools "statistically sample" individuals' different characteristics. As we argued above, however, there is no obvious reason why every redistributive tool should sample with respect to every proxy rather than have the income tax system sample for information on income and the tort system sample for information on accident proneness. If, however, Sanchirico is right in his empirical claim that there is some capacity constraint on the amount of income redistribution the tax system can do (say, the amount of information the tax authority is able to gather justifies a redistribution from $A$ to $B$ of only $\$ 20$ ), or if a behavioralist-probabilistic tax story could be told, ${ }^{271}$ then there would be an argument for using the tort system (as well as the tax system) to redistribute to reduce the income inequality. ${ }^{272}$ But not otherwise.

\section{Revisiting Old Objections}

As we described above, there are a number of arguments that have been used to support the traditional view - that income-based redistribution should be limited entirely to the tax-and-transfer system. Those included the contracting-around argument, the haphazardness argument, and the double-distortion argument. In our view, at least the first of those two arguments, though often overstated, does tend to support relying primarily on the tax-and-transfer system to reduce income inequality. An important question for our framework, then, is whether the same is true for other types of inequality. In particular, we focus here on the sorts of inequality that our examples involve: inequality due to differing disease-related genetic endowments, inequality of pain and suffering from personal injuries, and inequality with respect to ability to avoid accidents.

\section{The Contracting-Around Argument Revisited}

Previously we summarized what has come to be one of the most important criticisms of using legal rules to redistribute income: the argument that redistribution through legal rules is not feasible-it cannot be done-in settings in which the parties (those being redis-

271 See generally Jolls, Behavioral Economics, note 36.

272 See text accompanying notes 119-47. 
tributed to and from) are in contractual relationships with one another. ${ }^{273}$ In such settings, the argument goes, market forces would tend to undercut the redistributive effect of the rule. For example, a rule designed to redistribute "vertically" from manufacturers to consumers, on the theory that the former are richer than the latter, would run into problems of the following sort. Holding consumer demand constant, part of the redistributive effect would be reduced when the price of the products rises in response to the redistributive rule. And because consumer demand for the product would rise as well, it would be very difficult for the policymaker to design a rule that redistributes vertically in a way that makes consumers better off. ${ }^{274}$ As a result, income redistribution through contract-based legal rules is extremely difficult, albeit not impossible. ${ }^{275}$

One of the most interesting findings of our analysis is that, with respect to some nonincome measures of inequality, it is possible to design a contract-based legal rule that redistributes "horizontally" in a way that the contracting-around problem does not affect. Perhaps the best example is the class of insurance law rules that prohibit various types of discrimination in the underwriting process. For example, a rule forbidding insurers from discriminating on the basis of genetic information-such as on the basis of whether or not an insured has the Huntington gene-clearly is a contract-based legal rule. But the effect is not to redistribute vertically from insurer to insured; rather, it is to redistribute horizontally from one class of insureds (those without the Huntington gene) to another class of insureds (those who do have the gene). This is a type of redistribution through "pooling" or "cross-subsidization." With that sort of redistribution, there is no market force that will push those two classes of parties to contract around this result. 276

The example of pain-and-suffering damages, at least in the products liability context, provides another case in point. A rule requiring product manufacturers to pay pain-and-suffering damages to individuals who are injured by the manufacturer's products can be viewed as a contract-based redistributive rule. Obviously, consumers are in some sort of a contractual relationship with manufacturers. But the redistri-

273 See discussion in Subsection III.B.1.

274 This conclusion assumes that consumers are heterogeneous with respect to their preferences for the redistributive rule.

275 See text accompanying notes $68-83$.

276 While it is true that competitive forces will give insurers an incentive, in a sense, to evade this result by finding other proxies that are not prohibited by law, the law ideally should respond by prohibiting all such additional proxies as well (to the extent they represent brute luck-based measures of differences in well-being). This is another example of the distinction between the contracting-around problem and the income-shifting problem discussed above. 
bution accomplished by such a rule, at minimum, occurs horizontally. That is, as product prices rise to reflect what is in effect an insurance premium being charged for pain-and-suffering losses, all consumers contribute equally. Once the accidents occur, however, it is only those who have suffered the nonpecuniary harms who actually recover from the pool of funds. Thus, the products liability doctrine imposing painand-suffering damages on the manufacturer of a defective product that causes injury involves, at minimum, a type of redistribution from those who do not suffer nonpecuniary losses (who pay the higher price, but get no payment in return) to those who do suffer nonpecuniary losses (who pay the same higher price, but also recover an award after the accident). Under our framework there is no reason to rule out a priori horizontal redistribution as unwarranted.

A similar conclusion applies to our accident-proneness example: Changing the due care standard from an objective one to a subjective one, in general, should not have much of a redistributive effect on the class of defendants. Such a shift, however, would cause a horizontal transfer to the less able.

\section{The Haphazardness Argument Revisited}

The haphazardness complaint that is lodged against income-adjusted legal rules also does not have the same force when applied to nonincome-based redistributive legal rules, when the nonincome characteristic is not easily observed. Recall that the haphazardness critique includes both a complaint about inaccuracy and a complaint about underinclusiveness. The problem with this critique is that, with respect to nonincome characteristics, the tax-and-transfer system will not necessarily be more precise or more inclusive.

For example, the advantage of a subjective due care standard (and of pain-and-suffering damages) in tort law from a distributional perspective (as well as from an efficiency perspective) would be its potential for precision beyond what could be imagined in a broad-based tax approach. That is, a court hearing a tort case would be better able to observe whether the individual defendant is above average or below average with respect to accident proneness than a tax collector would. The court would have a comparative advantage at observing an individual's ability to avoid accidents (or costs of care) because making that assessment would enhance the efficiency of the legal rule as well. The same holds if defendants ex ante could observe the below-average potential victims and take excessive care in those instances.

In the case of insurance discrimination on the basis of disease-related genes, denying the use of such genes-to produce cross-subsidizing transfers from those without the genes to those with them- 
would seem to provide a considerably greater degree of accuracy in the amount of the transfer than could be accomplished through the tax-and-transfer alternative.

As for the underinclusiveness complaint, it is of course true that all of the rules we describe in this Section are underinclusive in the following sense: There will be some accident-prone people who will not be affected by the rule (either because it will not affect their accidentavoidance incentives or because they will not have insurance), there will be some individuals who will experience pain and suffering not in connection with a tort suit (and thus will not be able to collect damages), and there will be some individuals with disease-related genes who will not have insurance (and who thus would not benefit from the cross-subsidization our proposed rule would engender). All of those statements are true. It is not clear, however, that the tax-and-transfer system could do a better job. With respect to accident proneness, the tax-and-transfer system conceivably could be more comprehensive, but, again, at some considerable cost in terms of reduced accuracy or substantially higher administrative costs. The same could be said for nonpecuniary losses and disease-related genes.

\section{The Double-Distortion Argument Revisited}

The double-distortion argument does not apply to the rules discussed in this Section (redistribution with respect to accident proneness, nonpecuniary losses, or genetic diseases), since redistribution on the basis of proxies other than income does not entail a work distortion. It is not that we have found a way to avoid the use of proxies for well-being. To the contrary, proxies for well-being would have to be used in these settings as well. Thus, if society were to get serious about reducing accident-proneness inequality (which, again, we are somewhat skeptical of), then courts would have to make use of some sort of proxy or set of proxies. Likewise, in the context of pain-andsuffering damages in tort cases, when it comes to determining the appropriate amount of the redistributive transfer (that is, damage payment), a range of proxies is possible, from case-by-case testimony concerning the degree of emotional distress associated with a particular injury to a more standardized approach (where certain injuries automatically give rise to certain amounts of pain-and-suffering damages). The point is that the well-being proxies we identified in this Section (unlike, say, income or wealth) do not correlate with work effort in any obvious way. Genetically-determined diseases, of course, may be the best example, the purest instance of a well-being proxy that is representative of brute-luck inequality-and hence unconnected to work effort. 
Furthermore, as we argued above, we have identified examples of redistributive legal rules in the tort and insurance contexts that either produce no distortion or tend to reduce distortions. For example, the subjective-negligence standard (rather than a standard based on the "reasonable person") not only has redistributive benefits-shifting resources from the more able to the less able-but also enhances the deterrence function of tort law. The same goes for pain-and-suffering damages. Awarding pain-and-suffering damages actually enhances deterrence by forcing potential injurers to bear the full costs of their decisions, not just the pecuniary costs. ${ }^{277}$ Moreover, even if these rules were considered inefficient, we have identified independent, distributive justice grounds for adopting them.

\section{Conclusion}

The conventional wisdom among law and economics scholars seems to be that redistributive policy should focus on income inequality and that the task of redistribution should be left exclusively to the tax-andtransfer system. As to this latter conclusion, political theorists seem to agree as well. One aim of this Article is to question this conventional wisdom. Although we agree that income or wealth inequality should be a primary target of the redistribution-minded policymaker (whether from a welfarist or a nonwelfarist perspective), we also believe that other types of inequality (or other proxies for unequal welfare) ought to be considered as well.

As to income inequality, according to our comparative-advantage framework, legal rules in some circumstances (in particular, as a small-scale income-based lump sum tax, along the lines that Jolls has suggested ${ }^{278}$ ) can usefully supplement the tax system in reducing income inequality. As we have emphasized, however, the effects of income-redistributive legal rules are complicated because of the presence of liability insurance, which will exacerbate some of the inefficiencies of such rules but, at the same time, will enable liability insurance companies to serve as privatized tax collectors, supplementing the role currently monopolized by the Service.

With respect to nonincome measures of inequality, there may be many situations in which the legal system-or some hybrid of the legal system and the tax system-is either the better observer of the inequality in question, the better redistributor with respect to it, or both. We have focused on a few examples-genetically-determined dis-

277 See sources cited in note 215. This conclusion assumes that the cost of tailoring the negligent rule and the moral hazard effect of awarding pain-and-suffering damages are minimal.

278 Jolls, Behavioral Economics, note 36. 
eases, pain and suffering from personal injuries, and accident proneness. With respect to all of those types of inequality, redistribution through the legal system may be able to reduce brute luck-based inequality in a way that avoids the traditional conflict between efficiency and distributive justice.

Throughout this Article we assumed that there is a "redistributionminded policymaker," who has decided that some type and amount of redistribution is called for. In other words, some unspecified policymaker has chosen the type of inequality that is to be reduced and by how much. That assumption has allowed us to focus on the question of principal concern to us: how that policymaker might choose the optimal redistributive policy instrument, whether it be the legal system or the tax-and-transfer system, or some combination of the two.

As a result of this assumption, however, we have evaded the question of which policymakers-legislators or judges-should be responsible for making those initial decisions. Put more pointedly, should the legislature always be the policymaker that decides what type of redistribution and how much? Or is there some role for judges, acting to some extent independently of the legislature, in making such decisions? For example, should a court, acting independently of the legislature, attempting to implement what it sees as society's redistributive aims, adopt an income-redistributive tort tax or a subjective due care standard or pain-and-suffering damages in tort or a nondiscrimination principle in insurance law with respect to genetically-determined diseases? Or, instead, should the court implement such redistributive rules only after the legislature has first explicitly expressed its (and society's) "preference" for such redistribution?

There is a view that only legislatures should be allowed to make those initial redistributive determinations, never the courts. Most who hold this view seem to fall into one of two camps. ${ }^{279}$ First, some argue that there is (and should be) a theoretical and practical "isolation" between legal rules or private law on the one hand (the reasoning of which is somehow is considered "scientific" and devoid of value judgments) and society's distributive values, which are manifest through the legislature. ${ }^{280}$ Other critics of redistributive judicial initiatives ar-

279 Another possible view to support the division of labor conclusion is that the tax-andtransfer system is less intrusive to people's liberty than private law. We briefly touched upon this point at note 9. For a response see Kronman, note 9, at 501-07.

280 E.g., Ernest J. Weinrib, The Idea of Private Law 3-14 (1995). Weinrib argues, among other things, that private law, when rightly understood as being based on corrective justice (and not distributive justice), is "purely juridical and completely nonpolitical." Id. at 214 Weinrib also argues that social purposes, extrinsic to the relationship between the parties, even if they otherwise seem desirable, cannot be accommodated to the nature of private law justifications. Id. at 204-16. For a discussion of Weinrib's "isolation thesis," see Ha- 
gue that, even if court decisions are not isolated from society's values, the institutional role of the courts always should be to enforce the distributive status quo ante. This is because that status quo reflects the legislature's distributive values, which in turn reflect society's values.

In our view, the private law purist argument is based on a naive conception of private law. It should come as no surprise, given the general tenor of this Article, that we hold the view that private law can be legitimately redistributive. Moreover, there is much to be said for the view that private law is, in an important sense, inevitably distributive in character. ${ }^{281}$ Under this view, any judicial decision, whether it enforces the status quo ante or deviates from it, has some distributional consequences; there are winners and losers (besides the parties who litigate) in every court decision. And because, for any given violation of a legal rule or standard, there is always a menu of remedies for a court to choose from, by choosing one remedy and not the other, courts necessarily make a general distributive decisiongeneral in the sense of influencing not only the parties disputing before the court but also the "potential" parties that are subject to the court's jurisdiction. ${ }^{282}$ Thus, there is an important sense in which private law must be at least distributive, if not redistributive. ${ }^{283}$

noch Dagan, The Distributive Foundation of Corrective Justice, 98 Mich. L. Rev. 138, 142 54 (1999) [hereinafter Distributive Foundation].

281 Dagan, Distributive Foundation, note 280, at 147 (arguing that a nondistributive private law is an impossibility). Dagan argues that private law in general and the idea of property in particular cannot be seen as having an "inner intelligibility that can be deciphered without recourse to public values." Id. at 139. In Dagan's view, for example, property, as a human-created institution, is an open-textured term that is subject to different interpretations about its content and scope and always can be modified in accordance with society's changing values. Id. at 148 .

${ }^{282}$ To give a simple example, consider a case of nuisance. There are several different decisions courts can make, ranging from an injunction against the polluter to different levels of damages for the plaintiffs. Guido Calabresi \& A. Douglas Melamed, Property Rules, Liability Rules, and Inalienability: One View of the Cathedral, 85 Harv. L. Rev. 1089 (1972). As is well known, all of these decisions have different distributive consequences, not only for the parties disputing before the court but also for parties who may later be bound by the rule. For a menu of remedies in the law of restitution, see Dagan, Distributive Foundation, note 280, at 149.

283 In addition, not only do courts have a menu of different remedies to choose from for any given violation, but they also have a menu of efficient remedies to choose from. To mention just one example, it is well known that there are several Pareto optimal rules for the classic nuisance dispute. See Calabresi \& Melamed, note 282; James E. Krier \& Stewart J. Schwab, Property Rules and Liability Rules: The Cathedral in Another Light, 70 N.Y.U. L. Rev. 440 (1995); Louis Kaplow \& Steven Shavell, Property Rules Versus Liability Rules: An Economic Analysis, 109 Harv. L. Rev. 713 (1996); Ian Ayres \& Paul M. Goldbart, Optimal Delegation and Decoupling in the Design of Liability Rules, 100 Mich. L. Rev. 1 (2001); Ronen Avraham, Modular Liability Rules (John M. Olin Ctr. for Law \& Econ., Univ. of Mich. Working Paper No. 01-003, 2001), at http://papers.ssrn.com/sol3/papers.cfm?abstract_id $=272816$. Thus, a court's task, even according to the holders of the 
The second argument for limiting court-initiated redistributive policies - that is, the view that courts should always privilege the legislature-endorsed distributive status quo-goes to the question of what we mean by the term redistributive. The proponents of this view, unlike the private law purists, acknowledge that legal rules cannot be detached from their distributive consequences and thus from society's distributive values. In addition, however, they seem to believe that the legal status quo ante fully reflects society's distributive preferences. Hence, if a court renders a decision that upsets the distributive status quo, that court is redistributing. According to this view, courts should not redistribute; rather courts should avoid deviating from the distributive result inherent in the existing status quo, because, if the status quo did not reflect the legislature's (and by extension the citizenry's) distributive preferences, the legislature would have changed the laws. 284

This privilege-the-distributive-status-quo argument has some intuitive appeal. There are, however, a number of responses to it. We briefly summarize some of those responses here, without defending or endorsing any of them. As already mentioned, the basic thesis of our Article-and the comparative-advantage framework-can usefully apply however one reacts to the following arguments. Our objective at this point is only to get the relevant issues on the table.

First, it could be argued that the privilege-the-distributive-statusquo view ignores the teachings of public choice theory. For example, an adherent of public choice might contend that there is no single "preference" of the legislature with respect to anything (including distributional questions) but rather only the preferences of the different rent-seeking interest groups that lobby the legislators. Of course, there are good reasons to be skeptical of the strongest normative claims of public choice theory. For example, a radical public choice perspective would have difficulty explaining the strong and widely shared intuition that legislative outcomes-that is, statutes-generally are regarded as having the force of law.

privilege-the-distributive-status-quo view, cannot be stripped completely from distributive considerations, because the Kaldor-Hicks criterion in itself is indeterminate. Duncan Kennedy, Law-and-Economics From the Perspective of Critical Legal Studies, in 2 New Palgrave Dictionary, note 109 , at 470 . This has led Kennedy to argue that "it is hard to take seriously the proposal that the courts should just apply Kaldor-Hicks and stay out of distributive questions." Id.

284 To take an example of such legislative overruling from our framework, consider the case of pain-and-suffering damages in tort law. In many states, the legislatures became unsatisfied with state court rulings regarding pain-and-suffering damages. The result was that most state legislatures capped pain-and-suffering damages in all tort cases, some limited their scope to only some types of torts, and some did both. See generally Feldman, note 223 , at $1567-68$, and sources cited therein. 
Still, what we know about legislative interest group dynamics at least should make us also somewhat skeptical of the legislative status quo ante with respect to the worse off in society-those whom redistributive policy is supposed to benefit. Indeed, some hold the view that courts should have a leading role in protecting the welfare of disadvantaged groups, whose disadvantage sometimes is maintained by, if not the result of, the legislative dynamic in Congress. Thus, when the legislative process gives rise to systematic biases against a disadvantaged group, so goes the response, the courts might play an important role in initiating a redistributive response. 285

Second, even if we think that Congress, in some important sense, can have a unified preference about distributive matters, it is unlikely that the existing legislative status quo ante always will reflect that preference. Given the complexity of the legislative process and the costs of statutorily changing the law, it may be that in some cases the status quo does not reflect the existing legislature's distributional preferences. On this view, legislative "transaction costs" may prevent the legislature from enacting what are, in some sense, its true preferences; and courts adopting redistributive rules might be viewed as attempting to capture the legislature's unspoken (as yet unenacted) true preferences.

Of course, the contrary view is that those "legislative transaction costs" are really "benefits" in the sense that they prevent legislation from being enacted that has not met a sufficiently high threshold of support in Congress; and courts that try to adopt Congress' unenacted preferences are being unduly activist. Our point is only that the latter interpretation need not always trump the former. At least sometimes, we can imagine courts getting ahead of the legislature in a way that the legislature, in an important sense, approves of. What is more, we are not talking about constitutional lawmaking. Whatever redistributive rule the court might adopt could be reversed by the legislature, if the court in fact has misread the legislature's intent. ${ }^{286}$

A final response to the privilege-the-distributive-status-quo argument is at base an undemocratic one. It can be argued that, even if legislative decisions (including their silences) fully reflect the prefer-

285 As one obvious example, consider the fact that for many years Congress' endorsement of (or inaction with respect to) racial discrimination was clearly (and to some extent still may be) responsible for the existing distribution of benefits and burdens along racial lines.

286 See generally Guido Calabresi, A Common Law for the Age of Statutes (1982). Thus, taking our example of the subjective due care standard in tort, there is no reason to presuppose that state legislatures' silence on the issue is a deliberate distributive decision. It is just as likely that the silence is due to the legislatures' unawareness of the regressive cross-subsidization embedded in the objective, untailored standard. 
ences of the society as a whole, universal principles of justice sometimes should trump society's preferences. Of course, identifying the occasions when judges, rather than legislators, should be the expositors of such "universal principles" is notoriously difficult. Still, to say that courts should never engage in such an enterprise seems difficult to defend. ${ }^{287}$

287 Some scholars also contend that the privilege-the-distributive-status-quo position ignores important expressive dimensions of the law. According to this view, it is problematic to accommodate in the same legal culture a purely self-interest-driven, efficiency-based, ostensibly nonredistributive private law with an egalitarian, expressly redistributive system of taxation and transfers. As Hanoch Dagan puts it, " '[i]t seems artificial ... to expect that the same person who is not required to pay (almost) any attention to the fate of others' with respect to her private property 'will recognize the legitimacy of the claims of others (equally strangers) [with regard] to fragments of her resources when the tax collector asks his due.'" Dagan, Takings, note 40, at 792 (quoting Hanoch Dagan, Unjust Enrichment: A Study of Private Law and Public Values 57-58 (1997)). 
